\title{
AVALIAÇÃO DO GRAU DE EFICIÊNCIA DO TRATAMENTO DA CLASSE II REALIZADO SEM EXTRAÇÕES E COM EXTRAÇÕES DE DOIS PRÉ-MOLARES SUPERIORES
}

SÉRGIO ESTELITA CAVALCANTE BARROS

Dissertação apresentada à Faculdade de Odontologia de Bauru da Universidade de São Paulo, como parte dos requisitos para obtenção do título de Mestre em Odontologia, área de Ortodontia.

(Edição Revisada)

BAURU

2004 



\section{AVALIAÇÃO DO GRAU DE EFICIÊNCIA DO TRATAMENTO DA CLASSE II REALIZADO SEM \\ EXTRAÇÕES E COM EXTRAÇÕES DE DOIS PRÉ-MOLARES SUPERIORES}

SÉRGIO ESTELITA CAVALCANTE BARROS

Dissertação apresentada à Faculdade de Odontologia de Bauru da Universidade de São Paulo, como parte dos requisitos para obtenção do título de Mestre em Odontologia, área de Ortodontia.

Orientador: Prof. Dr. Guilherme Janson

(Edição Revisada)

BAURU 


\section{BARROS, Sérgio Estelita, Cavalcante}

B278a Avaliação do grau de eficiência do tratamento da Classe II realizado sem extrações e com extrações de dois pré-molares superiores / Sérgio Estelita Cavalcante Barros. - Bauru, 2004.

152p. mais apêndices: il.; $30 \mathrm{~cm}$

Dissertação (Mestrado) - Faculdade de Odontologia de Bauru. Universidade de São Paulo.

Orientador: Prof. Dr. Guilherme Janson

Autorizo, exclusivamente para fins acadêmicos e científicos, a reprodução total ou parcial desta dissertação, por processos fotocopiadores e/ou meios eletrônicos.

Assinatura do autor:

Data:

Projeto de pesquisa aprovado em 18 de fevereiro de 2004 pelo Comitê de Ética em Pesquisa da FOB.

Processo $n^{\circ}$ 08/2004 


\section{Universidade de São Paulo \\ Faculdade de Odontologia de Bauru}

Al. Dr. Octávio Pinheiro Brisolla, 9-75 - Bauru-SP - CEP 17012-901 - C.P. 73

PABX (0XX14)235-8000 - FAX (0XX14)223-4679

Pós-Graduação

e-mail: posgrad@fob.usp.br-Fone:(0XX14)235-8223

FOLHA DE APROVAÇÃO

Dissertação apresentada e defendida por SÉRGIO ESTELITA CAVALCANTI BARROS

e aprovada pela Comissão Julgadora em $1^{\circ}$ dezembro de 2004.
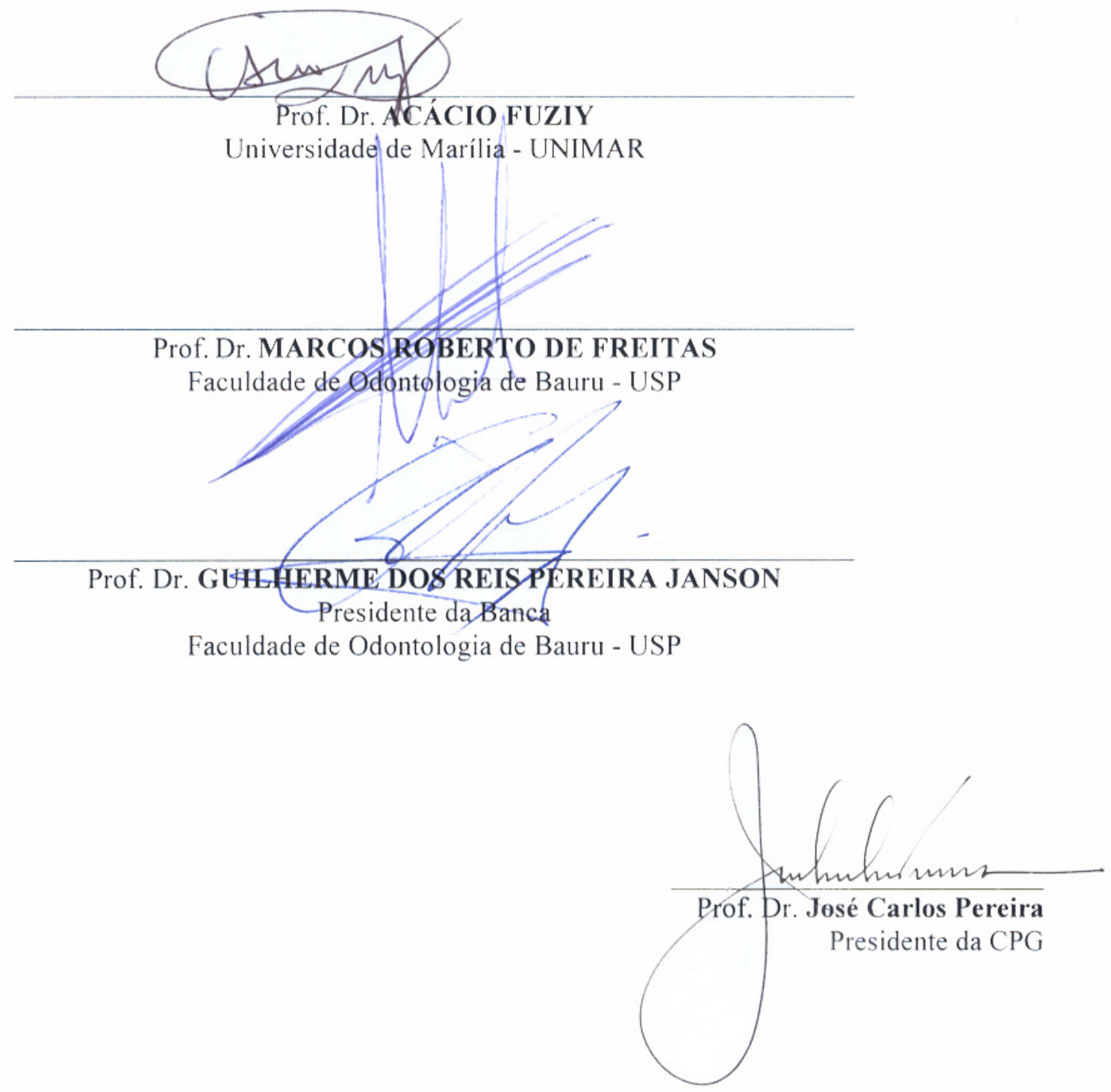


\title{
SÉRGIO ESTELITA CAVALCANTE BARROS
}

\author{
19 de setembro de $1968 \quad$ Nascimento
}

Goiânia - GO

Filiação

Edson Carvalho Barros

Glória Maria Estelita Barros

$1987-1992$

Curso de graduação em Odontologia pela

Faculdade de Odontologia "João

Prudente" - Anápolis (GO).

$1995-1997$

Curso de aperfeiçoamento em Ortodontia pela ACOPEN.

$1999-2001$

Curso de especialização em Ortodontia e Ortopedia Facial pela Faculdade de Odontologia de Bauru, Universidade de São Paulo.

$2003-2004$

Curso de Pós-graduação em Ortodontia, em nível de Mestrado, na Faculdade de Odontologia de Bauru, Universidade de São Paulo.

ASSOCIAÇÕES

SBPqO - Sociedade Brasileira de Pesquisas Odontológicas. 
"É preciso eliminar os mal-entendidos entre a fé e a ciência."

GALILEU GALILEI

No começo o homem criou DEUS, para que toda a sua ignorância pudesse ser explicada. À medida que a ciência foi iluminando a mente dos homens, muitos creram nela como um novo DEUS, enquanto outros a abominaram como um antiDEUS.

Penso que a ciência aproxima os homens de DEUS pelo poder da criação.

"Viver não é necessário. Necessário é criar." - FERNANDO PESSOA 


\section{Dedico este trabalho}

aos meus pais, Edson e Glória, que ao doarem grande parte de suas vidas à laboriosa tarefa de ensinar, levaram para dentro de casa o diaa-dia do ambiente acadêmico que hoje me faz sentir em casa.

Obrigado por me ajudarem e incentivarem na realização deste ideal. Por compreenderem e respeitarem a intensidade com que envolvo com as minhas atividades, pois esta é uma característica da qual nunca consegui me desvencilhar. Serei eternamente grato à enorme devoção e amor à família que sempre demonstraram e também à dedicação, seriedade e honestidade com que sempre desenvolveram suas atividades profissionais, permanecendo em minha mente como um exemplo constante.

ao meu filho Pedro Henrique a quem nunca

oferecerei menos do que o amor de um pai.

Sei que não estive ao seu lado diariamente, mas o amor que sinto por você me acompanha como se fosse a minha própria sombra. E não importa de onde venha a luz, pois basta que ela exista e lá estará a sombra, assim como não importa de onde venha o amor, basta que ele exista e lá estaremos nós, porque amor é tudo o que eu sinto e o que me une a você.

Eu não sei se sou o pai que você pediu a Deus, mas sei que sou o pai a quem Deus pediu para olhar por você e é isto que eu tenho feito com todos os meus acertos e erros. E se os meus acertos the servirem de guia para errar menos e os meus erros the ajudarem a acertar mais, então para mim, toda a minha vida como seu pai terá valido a pena.

O amor de um pai é uma árvore generosa de seiva vermelha e pulsante que tem suas raízes no coração. 


\section{AGRADECIMENTOS ESPECIAIS}

Aos meus irmãos Júnior, Fátima e Mariângela pelos

sentimentos de amor, perseverança e determinação

que sempre unirão os nossos espíritos por maiores que sejam as distâncias entre nós. 
Ao Prof. Dr. Guilherme Janson

meu orientador e coordenador do curso de Pós-

Graduação em Ortodontia ao nível de Mestrado,

Pelas experiências e conhecimentos transmitidos de maneira crítica e sábia;

Pela liberdade de pensamento e argumentação,

permitindo o surgimento de novas idéias e a criação

de novos conceitos;

Pela confiança em mim depositada;

Pela amizade e consideração demonstrada e

Pelas excelentes orientações prestadas a este

trabalho, levando a concluir que:

A priori, um orientador não deveria ser um definidor de caminhos, mas ao contrário, deveria ser uma verdadeira fonte geradora de novos caminhos para que o conhecimento e a sabedoria pudessem ser aplicados na escolha do melhor deles.

"Não podeis ensinar coisa alguma a um homem; podeis apenas ajudá-lo a encontrá-la dentro de si mesmo" (Galileu Galilei)

"Nunca ande pelo caminho traçado, pois ele conduz somente até onde os outros já foram."

(Alexander Graham Bell) 


\section{Minha gratidão}

Ao Prof. Marcos Roberto de Freitas, Chefe do Departamento Odontopediatria, Ortodontia e Saúde Coletiva, por transmitir de maneira tão despojada, simples e objetiva conhecimentos clínicos importantes, provenientes de uma grande experiência acumulada.

Ao Prof . Dr. José Fernando Castanha Henriques, Professor Titular e Coordenador do Curso de PósGraduação em Ortodontia, ao nível de Doutorado, pela perseverança e determinação em continuar contribuindo de forma relevante à nossa formação, não obstante as responsabilidades administrativas assumidas na condição de prefeito deste Campus.

Ao Prof Dr. Arnaldo Pinzan por se preocupar não apenas com a propagação do conhecimento científico, mas também com a formação de um espírito crítico e de uma visão contextualizada da ortodontia.

Ao Prof. Dr. Renato Rodrigues de Almeida pela forma acessível e amiga com que se relaciona com o corpo discente, facilitando o aprendizado e a troca de informações. 
Ao Prof. Dr. Décio Rodrigues Martins pela incontestável dedicação e competência no direcionamento científico da prática docente, acrescentando experiência e cultura à nossa formação.

Aos colegas do curso de mestrado Adriana, Alexandre, Darwin, Fernando Pedrin, Fernando Torres, Lívia, Marcos, Marcus, Paula, Rafael, Renata e, em especial à Kelly, pelos momentos de agradável convívio e colaboração mútua.

Ao Prof. Dr. Alberto Consolaro, pelo conhecimento e sabedoria que, por vezes, mudaram positivamente a minha maneira de agir e pensar.

Ao Prof. José Roberto Lauris por acrescentar à minha formação valiosos conhecimentos de estatística.

Aos funcionários da biblioteca pela atenção e serviços prestados.

Aos funcionários do Departamento de Ortodontia Vera, Cristina, Sérgio e Neide, pela colaboração e amizade.

Aos técnicos Daniel e Danilo pela colaboração e auxílio em vários aspectos no campo da informática. 


\section{Agradecimentos Administrativos}

À Prof. Dr. Maria Fidela de Lima Navarro, Diretora da Faculdade de Odontologia de Bauru - USP

Ao Prof. Dr. José Carlos Pereira, Presidente da Comissão de PósGraduação da Faculdade de Odontologia de Bauru - USP

À CAPES pela concessão da bolsa de estudo durante o curso de mestrado 


\section{SUMÁRIO}

LISTA DE FIGURAS .............................................................................

LISTA DE TABELAS ...........................................................................xV

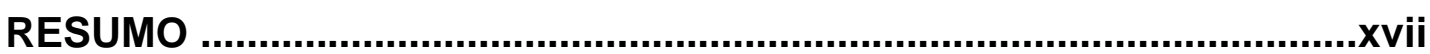

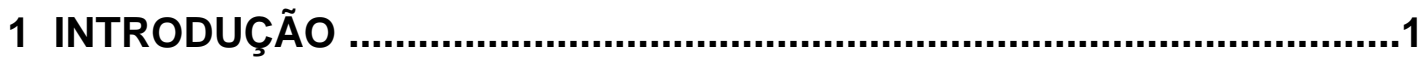

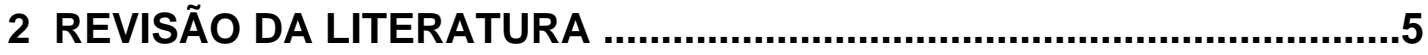

2.1 A época de tratamento da má oclusão de Classe II ...........................6

2.2 Tratamento ortopédico da má oclusão de Classe II ............................12

2.3 O tratamento ortodôntico da má oclusão de Classe II, com e sem extrações ..................................................................17

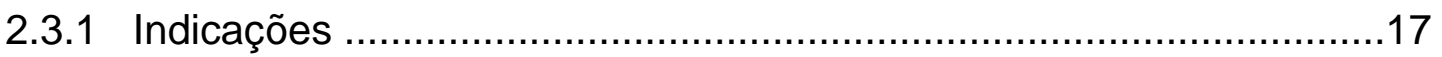

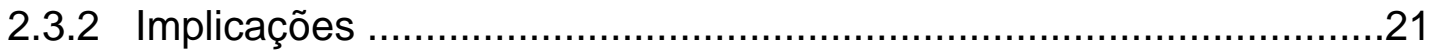

2.3.3 A correção e a estabilidade do apinhamento ântero-inferior .............30

2.3.4 O tempo de tratamento ............................................................31

2.3.5 A retenção do terceiro molar ..............................................33

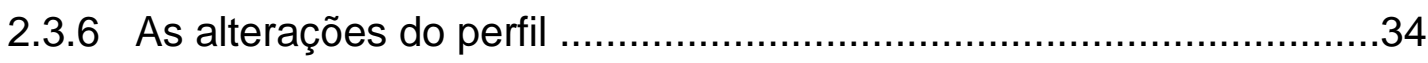

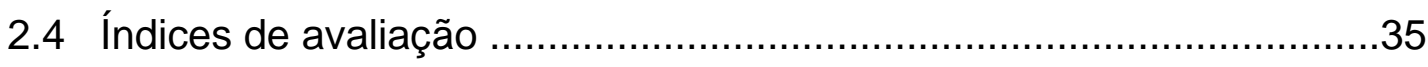

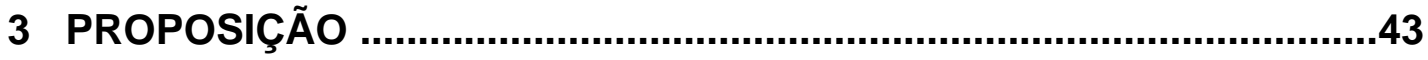

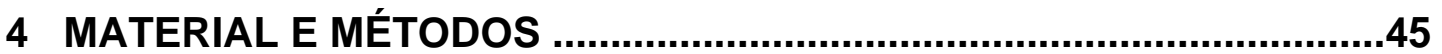

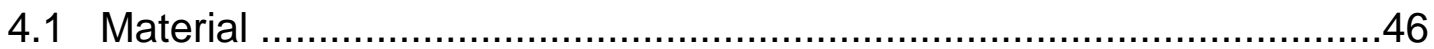

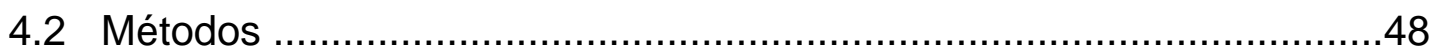

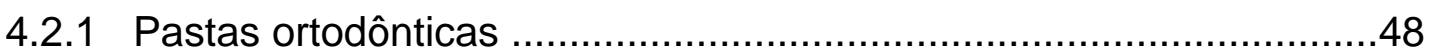

4.2.2 Os índices oclusais IPT e PAR ............................................49

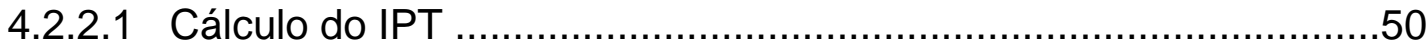

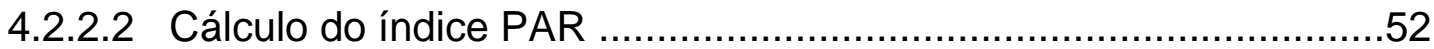

4.2.3 O índice de eficiência do tratamento (IET) ..................................55 
4.2.4 Descrição das abreviaturas utilizadas para representar as variáveis estudadas .56

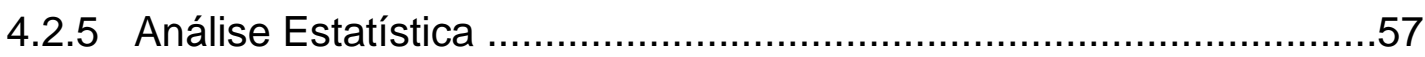

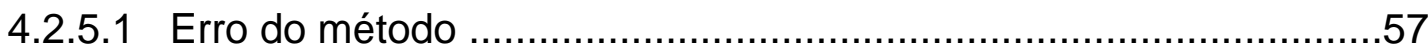

4.2.5.2 Análise estatística entre grupos e variáveis .............................57

5 RESULTADOS 64

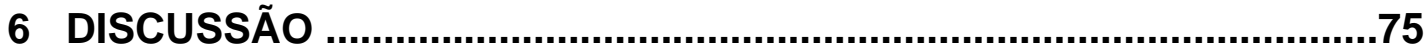

6.1 A amostra utilizada .............................................................

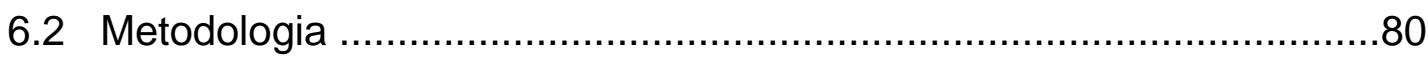

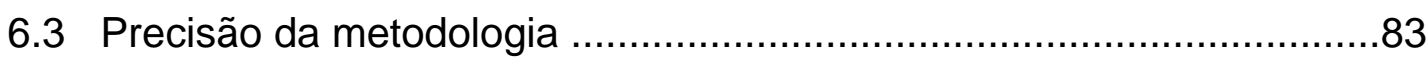

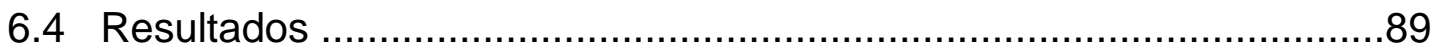

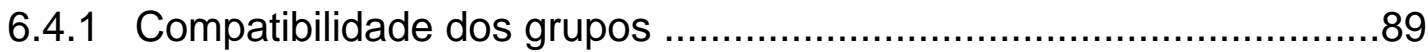

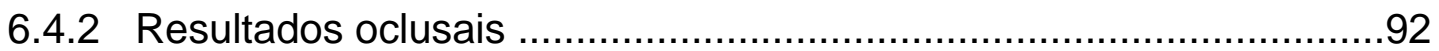

6.4.3 A influência do replanejamento (extrações tardias).......................104

6.4.4 A influência do tratamento em duas fases ...................................106

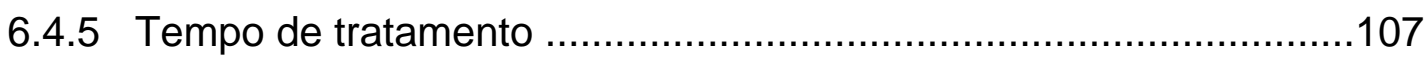

6.5 A eficiência do tratamento ortodôntico .........................................115

6.6 Avaliação dos índices oclusais .................................................117

6.7 Considerações clínicas ...........................................................118

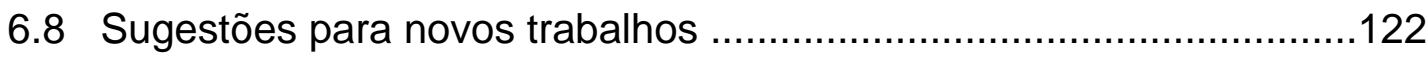

7 CONCLUSÕES .........................................................................123

REFERÊNCIAS BIBLIOGRÁFICAS ...................................................125

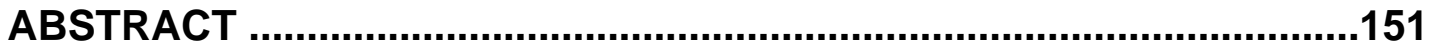

\section{APÊNDICE}




\section{LISTA DE FIGURAS}

FIGURA 1 - Correção da má oclusão de Classe II completa, sem extrações. 102

FIGURA 2 - Correção da má oclusão de Classe II completa, com extrações de dois pré-molares superiores. ...............................................103 


\section{LISTA DE TABELAS}

TABELA 1 - Critérios de aplicação dos escores para os componentes do índice IPT. 62

TABELA 2 - Critérios de aplicação dos escores para os componentes do índice PAR.

TABELA 3 - Resultados do teste $t$ pareado e da fórmula de DAHLBERG ${ }^{60}$, aplicados às variáveis IPTI; IPTF; PARI e PARF para estimar os erros sistemáticos e casuais, respectivamente. 68

TABELAS 4 e 5 - Resultados do teste Qui-Quadrado para avaliar a compatibilidade dos grupos quanto à proporção dos tipos de má oclusão e gênero. 68

TABELA 6 - Resultados do teste $t$ independente, aplicado às variáveis estudadas nos grupos 1 e 2 .

TABELA 7 - Resultados do teste $t$, considerando a compatibilidade dos grupos 1 e 2 quanto à idade inicial (IDADEI). 69

TABELA 8 - Distribuição percentual dos pacientes nos grupos 1 e 2, de acordo com o valor do IPTF. 70

TABELA 9 - Distribuição percentual dos pacientes nos grupos 1 e 2, de acordo com o valor da variável PARF. .70

TABELA 10 - Resultados da Análise de Variância e teste de Tukey aplicados ao grupo 1 e subgrupos $2 A$ e $2 B$. .71

TABELA 11 - Resultados do teste $t$, considerando o grupo 1 e o subgrupo $2 \mathrm{~A}$ compatíveis quanto à idade inicial (IDADEI). 
TABELA 12 - Resultados do teste $t$, aplicado ao subgrupo 1B (tratamento em duas fases, sem extrações) e grupo 2 (tratamento com extrações). .72

TABELA 13 - Resultados do teste $t$, aplicado aos subgrupos 1A (tratamento em uma fase, sem extrações) e $\mathbf{2 A}$ (tratamento com extrações, sem replanejamento). ................................................ 72

TABELA 14 - Resultados da análise de regressão múltipla, considerando o valor final do índice PAR como variável dependente. 73

TABELA 15 - Resultados do teste de Mann-Whitney, aplicado aos valores finais de cada um dos componentes do índice PAR, nos grupos 1 e 2. .73

TABELA 16 - Resultados do teste de correlação aplicado às variáveis IPTF, PARF, PCIPT e PCPAR. 74

TABELA 17 - Resultados do teste $t$ independente aplicado às variáveis PCIPT e PCPAR. .74 


\section{RESUMO}




\section{RESUMO}

O objetivo deste trabalho foi comparar o grau de eficiência do tratamento da má oclusão de Classe II completa, realizado sem extrações e com extrações de dois pré-molares superiores. Para tanto, selecionou-se, a partir de todas as 3592 documentações do arquivo da disciplina de ortodontia da Faculdade de Odontologia de Bauru, uma amostra composta pelas documentações de 112 pacientes com má oclusão de Classe II completa. Em seguida, dividiu-se esta amostra em dois grupos, apresentando as seguintes características: Grupo 1, constituído por 43 pacientes, tratados sem extrações e com idade inicial média de 12,63 $\pm 1,45$ anos (idade mínima de 9,39 e máxima de 16,03) e Grupo 2 composto por 69 pacientes, tratados com extrações de dois pré-molares superiores e com idade inicial média de 13,91 $\pm 2,71$ anos (idade mínima de 9,42 e máxima de 27,08$)$. Para comparar o grau de eficiência do protocolo de tratamento aplicado a cada grupo, os resultados oclusais do tratamento foram avaliados em modelos de gesso por meio dos índices oclusais IPT e PAR, enquanto o tempo despendido no tratamento de cada grupo foi calculado a partir das anotações clínicas presentes nos prontuários. O grau de eficiência foi calculado pela porcentagem de melhora oclusal, avaliada pelo IPT ou PAR, dividida pelo tempo de tratamento. Os índices oclusais finais, o tempo de tratamento e o grau de eficiência dos protocolos de tratamento dos grupos foram comparados por meio do teste t. Os resultados demonstraram que 0 protocolo de tratamento com extrações de dois pré-molares superiores 
apresentou melhores resultados oclusais, num menor tempo de tratamento e, portanto um maior grau de eficiência, do que o protocolo sem extrações, da má oclusão de Classe II completa. 



$$
\text { INTRODUÇÃO }
$$




\section{INTRODUÇÃO}

Freqüentemente o ortodontista se depara com uma variedade de aparelhos, técnicas e protocolos de tratamento destinados à correção de um mesmo tipo de má oclusão. Esta diversidade de opções tende a causar, sobretudo nos profissionais menos experientes, dúvidas e indecisões quanto à escolha da abordagem que melhor se aplica a cada caso.

Atualmente, um dos mais importantes pontos de consenso entre os objetivos do profissional e os anseios do paciente se traduz na obtenção dos melhores resultados possíveis em um menor tempo de tratamento. Segundo HOUAISS ${ }^{106}$ alcançar o melhor rendimento com o mínimo de dispêndio de tempo significa eficiência. Portanto o que os profissionais e pacientes realmente desejam é a aplicação de um protocolo de tratamento que seja eficiente por excelência.

Para tanto, a elaboração do plano de tratamento jamais deve se basear em achismos, crenças, correntes "filosóficas" ou "ideológicas". Não se vive mais a época em que o ortodontista era classificado como extracionista ou não extracionista, no momento atual, as decisões são norteadas, sobretudo, por evidências científicas e o plano de tratamento deve refletir, acima de tudo, as necessidades do paciente e nunca os caprichos ou costumes do profissional.

Quando o tratamento da má oclusão de Classe II requer extrações no arco inferior em função da severidade do apinhamento ou da 
discrepância cefalométrica, não há dúvidas de que extrações também deverão ser realizadas no arco superior. Portanto, nestas circunstâncias a má oclusão de Classe II é tratada, com extrações de quatro prémolares $^{47,64,124,181,214}$

A questão surge quando a quantidade de apinhamento e/ou protrusão dos dentes no arco inferior apresenta-se numa condição limítrofe, permitindo que o tratamento seja realizado com ou sem extrações no arco inferior. Nestes casos, os três principais protocolos de tratamento da Classe II deverão ser considerados, o tratamento com extrações de quatro prémolares, dois pré-molares ou, ainda, sem extrações. Porém, conforme mencionado anteriormente, sempre que mais de um protocolo de tratamento pode ser utilizado na correção de um mesmo tipo de má oclusão, a escolha deverá incidir sobre o protocolo que comprovadamente apresenta maior eficiência, propiciando a obtenção dos melhores resultados num menor tempo de tratamento.

JANSON et al. ${ }^{113}$ e MARIA ${ }^{140}$, demonstraram que o protocolo de tratamento envolvendo extrações de dois pré-molares superiores produziu melhores resultados oclusais num menor tempo de tratamento quando comparado ao protocolo de quatro extrações, apresentando, portanto, um maior grau de eficiência no tratamento da má oclusão de Classe II completa. Os resultados destes trabalhos indicaram a necessidade de correção da relação molar como o fator que mais dificultou e prolongou o tratamento com quatro extrações. Sendo assim, a manutenção da relação molar, decorrente do tratamento da Classe II com extrações de dois pré- 
molares superiores, propicia a obtenção de um maior grau de eficiência. Nestes casos, as maiores movimentações se restringem aos dentes ânterosuperiores que são retraídos em direção ao espaço da extração, reduzindo o trespasse horizontal e obtendo-se uma relação de Classe I dos caninos $^{47,64,113,124,181,214}$.

Uma vez que a necessidade de correção da relação molar foi o fator que mais comprometeu a eficiência do protocolo de tratamento da Classe II com quatro extrações ${ }^{113,140}$, surgiu a hipótese de que um comprometimento semelhante poderia também ocorrer nos casos em que a má oclusão de Classe II completa é tratada sem extrações, haja vista que este protocolo de tratamento também pressupõe a correção da relação molar.

No intuito de investigar esta hipótese, propôs-se a comparação dos resultados oclusais e do tempo de tratamento da má oclusão de Classe II completa tratada sem extrações e com extrações de dois pré-molares superiores. 
REVISÃO DA LITERATURA 


\section{REVISÃO DA LITERATURA}

Considerando que o conhecimento das informações advindas do estudo do tratamento da má oclusão de Classe II realizado com e sem extrações dentárias são de igual relevância à execução deste trabalho, buscou-se, na revisão da literatura, avaliar as diversas modalidades de correção da Classe II, independente do protocolo de tratamento envolver ou não extrações dentárias. Sendo assim, o tratamento ortopédico com aparelhos extrabucais, aparelhos funcionais e o tratamento ortodôntico com aparelhos fixos, foram considerados. Além disso, foram revistas as principais implicações relacionadas ao tratamento ortodôntico realizado com e sem extrações de uma maneira geral. Por fim, realizou-se uma revisão dos índices oclusais, visto que este método de avaliação das relações dentárias intra e interarcos compôs a metodologia desta pesquisa.

\subsection{A época de tratamento da má oclusão de Classe II}

Em muitos casos o tratamento ortodôntico da má oclusão de Classe II, com extrações, é realizado numa época em que o paciente ainda se encontra numa fase ativa de crescimento e que, portanto, poderia ser tratado ortopedicamente. As afirmações de que a fase ortopédica do tratamento proporciona diferenciados benefícios à correção da Classe II $^{19,90,132,176,222}$ colocam em questionamento a qualidade dos resultados obtidos quando o tratamento desta má oclusão é realizado apenas 
ortodonticamente numa fase mais tardia do desenvolvimento. Sendo assim, buscou-se na literatura estabelecer os princípios que fundamentam a indicação do tratamento ortopédico da má oclusão de Classe II, bem como as possíveis vantagens e desvantagens decorrentes desta abordagem.

Embora as características morfológicas da má oclusão de Classe II comecem a se delinear num estágio bastante precoce do desenvolvimento ${ }^{12,129}$, a melhor época para o tratamento desta má oclusão permanece como uma questão clínica de grande controvérsia na literatura. Segundo PROFFIT; TULLOCH ${ }^{162}$ (2002), o âmago do debate não consiste em provar que a má oclusão de Classe II pode ser corrigida em vários estágios do desenvolvimento, pois existem evidências clínicas suficientes de que isto é geralmente possível. Para os autores, a principal questão a ser esclarecida é se o tratamento precoce da Classe II, quase sempre sucedido por uma segunda fase de tratamento, pode surtir melhores resultados que 0 tratamento convencional, realizado em uma única fase, na dentição permanente.

A maioria dos pacientes que exibe uma relação oclusal de Classe II de moderada a severa, apresentam, concomitantemente algum tipo de discrepância esquelética, advinda, principalmente, de uma deficiência mandibular ${ }^{120,144,162}$. Sendo assim, a abordagem precoce teria como objetivo a modificação do crescimento, além de reduzir significativamente a necessidade de extrações dentárias, tornando o tratamento subseqüente com aparelhos fixos, restrito ao alinhamento dos dentes e refinamento da oclusão $^{19,222}$. Porém, esta argumentação, segundo PROFFIT; TULLOCH ${ }^{162}$ 
(2002), suscita três importantes questões: (1) o crescimento pode realmente ser modificado? e se pode, quais são os limites e a previsibilidade?; (2) diferentes aparelhos podem realmente produzir diferentes efeitos terapêuticos?; (3) qual o impacto que a intervenção precoce teria sobre o tratamento ortodôntico subseqüente? a segunda fase do tratamento seria realmente mais simples, rápida e com melhores resultados?

Considerando estas questões, BASS $^{19}$, em 1983, e vários outros autores constantes na literatura ${ }^{19,90,132,176,222}$, concluíram que os principais benefícios provenientes da correção da má oclusão de Classe II são alcançados na fase ortopédica do tratamento e compreendem: (1) coordenação do crescimento maxilo-mandibular ${ }^{19,90,176,222}$; (2) melhor estética facial subseqüente ao tratamento, e na fase adulta ${ }^{19}$; (3) equilíbrio precoce da musculatura orofacial $^{19,132,176} ;$ (4) garantia de melhor estabilidade da correção em casos mais severos ${ }^{19,90}$; (5) diminuição do percentual de pacientes que necessitam de correção ortodôntico-cirúrgica ${ }^{19,176} ;(6)$ redução no risco de fraturas e avulsões dos incisivos superiores ${ }^{19,90,132}$; (7) menor dependência do crescimento crânio-facial para o sucesso da terapia corretiva, podendo ser iniciada na época mais oportuna para o paciente ${ }^{19}$; (8) alteração imediata da relação sagital pelo aparelho, motivando a cooperação do paciente durante a fase ortopédica e mantendo esta motivação na fase de correção com os aparelhos fixos ${ }^{19}$; (9) redução significativa da necessidade de extrações de dentes permanentes para a correção da sobressaliência ${ }^{19,90,176,222}$; (10) menor quantidade de movimentação dentária na fase corretiva $^{19}$; (11) redução do tempo de 
tratamento com aparelhos fixos, diminuindo seus efeitos indesejáveis ${ }^{90,222}$; (12) melhora na auto-estima do paciente ${ }^{132,138}$.

Os efeitos benéficos do tratamento precoce realizado com bionator ou AEB sobre o padrão esquelético da má oclusão de Classe II foram, segundo TULLOCH et al. ${ }^{199}$, extremamente variáveis e algumas vezes indistinguíveis quando comparados a um grupo controle sem qualquer tratamento. Para saber se os benefícios, obtidos na primeira fase, se perpetuariam na fase seguinte do tratamento, a mesma amostra foi acompanhada por TULLOCH; PHILLIPS; PROFFIT ${ }^{200}$ (1998), que não observaram qualquer diferença na relação dentária ou maxilo-mandibular entre o grupo de pacientes submetidos precocemente ao tratamento ortopédico com bionator ou AEB e o grupo controle, que recebeu tratamento ortodôntico em uma única fase. Em relação ao tempo de tratamento, o grupo tratado em duas fases apresentou um menor período de permanência com o aparelho fixo, porém o tempo total de tratamento foi maior para este grupo quando as duas fases foram contabilizadas $^{24}$. Além disso, o número de extrações dentárias requeridas foi maior no grupo tratado precocemente com aparelhos funcionais e a cirurgia ortognática foi uma opção de tratamento cogitada mesmo para aqueles que receberam o tratamento em duas fases.

Estes resultados corroboram a afirmação de JOHNSTON $^{117}$ (2002) de que os aparelhos funcionais não constituem um substituto para a cirurgia ortognática, muito menos criam espaços numa dentição protruída e apinhada, para evitar a extração de pré-molares. O autor ainda pondera que os benefícios do tratamento precoce da Classe II podem estar restritos a 
uma melhora da auto-estima do paciente e à prevenção de trauma nos incisivos.

Visto que uma baixa auto-estima e uma imagem negativa tem sido associada a pacientes com má oclusão de Classe II e trespasse horizontal aumentado, DANN et al. ${ }^{62}$, em 1995, realizaram uma pesquisa envolvendo 208 pacientes com idade entre 7 e 15 anos e portadores de má oclusão de Classe II com trespasse horizontal maior ou igual a 4,5mm. O autor concluiu que as crianças com má oclusão de Classe II não se apresentam ao tratamento com uma baixa auto-estima e que, em média, a auto-estima dos pacientes tratados não aumenta durante o breve período do tratamento. Portanto, o valor da auto-estima como justificativa para o tratamento ortodôntico precoce pode estar sendo superestimado ${ }^{67}$.

Ao indagar a opinião dos ortodontistas a respeito do impacto do tratamento precoce da Classe II sobre a segunda fase de tratamento, KING et al. $^{127}$ concluíram que os ortodontistas não consideram o tratamento precoce da Classe II como uma terapia destinada a prevenir uma segunda intervenção ou, evitar a realização de extrações.

Segundo PROFFIT; TULLOCH ${ }^{162}$ (2002), quando uma má oclusão de Classe II é diagnosticada em crianças com idade esquelética bem à frente da idade dentária, ou mais propensas a acidentes, ou, ainda, com relevante padrão vertical associado, o tratamento precoce pode estar indicado. Porém, em geral, os autores concluíram que mudanças induzidas precocemente no crescimento, embora variem de acordo com aparelho utilizado, não se mostram mais efetivas em corrigir a relação esquelética e 
dentária da Classe II do que o tratamento convencional, realizado em uma única fase, na dentição permanente ${ }^{67}$. Para os autores, o tratamento precoce não apenas falhou em prover alguma vantagem ou simplificação do tratamento, como também o tornou mais longo.

A utilização de aparelhos funcionais numa fase precoce do desenvolvimento, buscando otimizar o crescimento esquelético da face foi também avaliado por LIVIERATOS; JOHNSTON ${ }^{137}$, em 1995, que compararam os resultados do tratamento realizado em duas fases (Bionator/Edgewise) com aquele realizado em uma única fase (Edgewise). Ao final do tratamento as mudanças esqueléticas e dentárias, responsáveis pela correção da relação molar e trespasse horizontal, foram idênticas entre os grupos. Contudo, a magnitude das mudanças, medidas durante o tratamento, diferiu entre os grupos uma vez que o tratamento realizado em dois estágios iniciou mais cedo e terminou mais tarde, contabilizando cerca de um ano e meio de acréscimo. Além disso, o tratamento realizado em duas fases não eximiu os pacientes da necessidade de extrações dentárias, sendo que o maior número de pacientes com planos de tratamento alterados pela necessidade de extrações ou cirurgia ortognática pertenciam ao grupo tratado em duas fases. Sendo assim, a escolha entre uma ou outra forma de tratamento parece ser mais uma conduta habitual do que uma decisão com bases biológicas.

Para BOWMAN ${ }^{43}$, os tratamentos agressivos, aplicados precocemente com o intuito de prover a qualquer custo um tratamento ortodôntico sem extrações, deveriam ser evitados, pois não encontram 
suporte na literatura e podem, até mesmo, ter efeitos deletérios a longo prazo.

\subsection{Tratamento ortopédico da má oclusão de Classe II}

Existem três possíveis abordagens para corrigir uma má oclusão de Classe II com discrepância esquelética: (1) modificação do crescimento para reduzir ou eliminar a discrepância maxilo-mandibular, uma vez que a mandíbula cresce mais do que a maxila; (2) movimentação dentária para compensar a discrepância entre as bases apicais, isto é, retração dos incisivos superiores e/ou vestibularização dos incisivos inferiores (camuflagem), mantendo a discrepância esquelética e (3) reposicionamento cirúrgico das bases apicais, envolvendo, freqüentemente, avanço mandibular, visto que a maioria das más oclusões de Classe II apresentam algum grau de deficiência da mandíbula ${ }^{92,159}$.

Com a proposição de corrigir a discrepância entre as bases ósseas, proporcionando uma melhor condição estética a curto e longo prazo, a modificação do crescimento proporcionada pela utilização dos aparelhos funcionais tem constituído ao longo dos anos uma forma de tratamento de grande aceitação pelos ortodontistas na correção da má oclusão de Classe II 19,53 .

A crença de que a melhora no perfil e na estética facial proporcionada pelos aparelhos funcionais é superior àquela advinda do tratamento ortodôntico convencional (com aparelhos fixos) ${ }^{152}$, foi 
questionada por BARRER; GHAFARI $^{15}$, em 1985, que avaliaram os resultados estéticos obtidos do tratamento ortodôntico realizado com aparelho de Fränkel, Beeg light-wire, straight-wire e edgewise, em uma mostra randomizada de pacientes apresentando má oclusão de Classe II, Divisão 1. Os autores concluíram que a estética facial avaliada a partir do contorno do perfil pré e pós-tratamento apresentou significativa melhora, porém, nenhuma das quatro modalidades de tratamento mostrou-se mais eficiente em produzir melhores perfis.

Inquirindo mais amplamente a crença sobre os efeitos diferenciados dos aparelhos funcionais na melhora do perfil, O'NEILL; HARKNESS;KNIGHT ${ }^{151}$, em 2000, compararam a mudança na atratividade do perfil de pacientes portadores de má oclusão de Classe II, Divisão 1 tratados com o aparelho de Fränkel, ativador e não tratados. Os resultados mostraram que não houve diferença significante na atratividade do perfil entre os pacientes do gênero masculino ou feminino, tratados com ativador ou Fränkel. Além disso, não foi observada, também, qualquer alteração significante na atratividade do perfil entre o grupo de pacientes tratados e não tratados, concluindo que o tratamento com aparelhos funcionais não levou a um perfil mais atrativo em relação àquele não tratado.

A escassez de melhoras no perfil dos pacientes tratados ortopedicamente pode refletir a verdadeira extensão das tão proferidas mudanças esqueléticas atribuídas à utilização destes aparelhos.

O fato de que os aparelhos ortopédicos promovem alterações esqueléticas nos maxilares que contribuem para a correção das más 
oclusões, sobretudo da má oclusão de Classe II, encontra-se bastante $\begin{array}{lllll}\text { estabelecido } & \text { e } & \text { fundamentado } & \text { nateratura }\end{array}$ vigente ${ }^{14,19,50,63,74,75,100,153,164,165,209211,217,221}$. Contudo, as modificações no complexo côndilo-fossa, favoráveis à correção da má oclusão de Classe II e observadas por VOUDOURIS et al. ${ }^{210,211}$, PANCHERZ; FISCHER ${ }^{153}$, BALTROMEJUS; PANCHERZ ${ }^{14}$, RABIE; HÄGG ${ }^{164}$ e RABIE et al. ${ }^{165,166}$, são válidas apenas enquanto o aparelho está sendo utilizado. Após o tratamento ortopédico, tanto as alterações qualitativas quanto as quantitativas, induzidas no crescimento, tendem a retornar aos parâmetros pré-tratamento. PANCHERZ ${ }^{153}$, em 2003, relatou que o período pós-tratamento foi acompanhado por uma menor quantidade de crescimento e por um retorno à direção de crescimento condilar mais vertical, semelhante àquela presente no período pré-tratamento. O remodelamento da fossa, que no período de tratamento foi redirecionado para anterior, retornou à direção posterior no período pós-tratamento.

A reversão dos efeitos do tratamento foi também observada por VOUDOURIS; KUFTINEC ${ }^{209}$, em 2000. Na analogia feita pelos autores, a remodelação do côndilo e da fossa sob a ação dos aparelhos funcionais assemelha-se a uma lâmpada num reostato. A transdução dos estímulos mecânicos gerados pelos aparelhos funcionais ao côndilo e à fossa articular intensifica a remodelação óssea que ocorre nesta região. Contudo, uma vez removido o estímulo mecânico ao final do tratamento, a remodelação vai diminuindo em intensidade, até atingir um nível basal. Além disso, os autores afirmaram que o retorno do côndilo à fossa e a restituição da função 
muscular ao final do tratamento, sobretudo do digástrico anterior, gera um maior nível de compressão nesta região, determinando um alto grau de recidiva das mudanças ${ }^{210}$. Sendo assim, o restrito tempo de tratamento associado à recidiva pós-tratamento faz com que nenhuma quantidade clinicamente significante de tecido ósseo adicional esteja presente a longo prazo.

As mudanças a longo prazo no comprimento mandibular foram também questionadas por DEVINCENZO ${ }^{63}$ que não observou qualquer impacto do tratamento ortopédico com aparelhos funcionais sobre o comprimento mandibular após 4 anos de observação. Embora o crescimento mandibular tivesse aumentado substancialmente durante o tratamento, a fase pós-tratamento foi marcada por uma proporção de crescimento mandibular inferior àquela observada no grupo controle. Resultados semelhantes foram reportados por WIESLANDER ${ }^{217}$, em 1993, quando avaliou os efeitos a longo prazo do aparelho de Herbst sobre o crescimento mandibular em pacientes portadores de má oclusão de Classe II severa. O autor observou que o significativo efeito protrusivo de $3,9 \mathrm{~mm}$, ocorrido durante a fase ativa de tratamento, reduziu para um valor não significante de 1,5mm no período pós-contenção, igualando-se ao grupo controle composto por pacientes portadores de má oclusão de Classe II, não tratados.

A literatura tem mostrado que o aumento do crescimento mandibular, produzido pelos aparelhos funcionais tende a não se perpetuar com o evolver do tempo, assemelhando-se aos efeitos produzidos por outras 
modalidades de tratamento para a Classe II que não incluem estes $\operatorname{aparelhos}^{58,63,72,86,102,118,153,210,217,218}$.

Algum efeito restritivo no crescimento maxilar resultante, principalmente, da utilização do AEB (aparelho extra bucal) associado ou não aos aparelhos funcionais e fixos, tem se somado à correção da má oclusão de Classe II, compensando parte da recidiva mandibular ${ }^{97,217}$, muito embora BERNSTEIN; ULBRICH; GIANELLY ${ }^{28}$ e GIANELLY; VALENTINI ${ }^{87}$ demonstraram por meio de um estudo cefalométrico, utilizando-se implantes metálicos, que a principal alteração maxilar decorrente do uso do AEB foi de ordem dentoalveolar. A falta de evidências científicas referentes à perpetuação dos efeitos ortopédicos gerados pelo aparelho extra bucal, aparelho de Herbst e ativador foi a principal conclusão da extensa revisão de literatura realizada por AELBERS; DERMAUT ${ }^{3,66}$, em 1996.

Considerando que: (1) as alterações dentoalveolares resultantes do tratamento ortopédico são proporcionalmente maiores ${ }^{37,68,102}$ (2) a menor proporção de alterações esqueléticas advindas do tratamento ortopédico tende a não se perpetuar ${ }^{63,96,102,153,210,217}$ e (3) o tratamento ortodôntico com aparelhos fixos são também acompanhados de alterações esqueléticas $^{72,118,137,169}$, pode-se especular que estas duas modalidades terapêuticas não se diferem significativamente quanto às mudanças estruturais ao final do tratamento, como de fato concluíram EDWARDS ${ }^{72}$ e GIANELLY; BERNSTEIN ${ }^{86}$. 


\subsection{O tratamento ortodôntico da má oclusão de Classe II, com e sem extrações}

\subsubsection{Indicações}

Assim como o tratamento ortopédico com aparelhos funcionais, o tratamento ortodôntico com aparelhos fixos apresenta efeitos predominantemente dentoalveolares ${ }^{37,68,86,102,149,169}$ que levam à correção da má oclusão de Classe II. Conforme foi ressaltado por JOHNSTON $^{117}$, em 2002, "é difícil entender como o crescimento pode criar espaço para uma dentição apinhada e protruída", corroborando este pensamento estão os resultados dos trabalhos que avaliaram o tratamento da Classe II, realizado em duas fases, mostrando que a fase ortopédica do tratamento não mostrou-se capaz de reduzir a necessidade de extrações na fase ortodôntica $^{127,137,162,200}$. Além disso, a severidade da má oclusão de Classe II, o reduzido potencial de crescimento frente à magnitude da discrepância ântero-posterior, a falta de cooperação do paciente, a preocupação com o perfil, o padrão de crescimento etc, constituem, segundo BAUMRIND et al. ${ }^{23}$, indicadores em potencial da necessidade de extrações dentárias. Ao submeter as documentações de 72 pacientes à avaliação de cinco ortodontistas sobre a necessidade ou não de extrações, bem como sua justificativa, BAUMRIND et al. ${ }^{23}$ observaram que numa ordem decrescente de quantidade de citações, o apinhamento, a protrusão dos incisivos, a necessidade para correção do perfil e a severidade da má oclusão de Classe II foram as quatro razões para extração mais citadas pelos avaliadores. 
Embora não estivessem entre os mais citados, o julgamento antecipado da falta de cooperação do paciente e o reduzido ou ausente potencial de crescimento do paciente constituíram um fator de agravamento do caso que, para alguns ortodontistas, justificou a indicação de extrações.

O grau de apinhamento e a protrusão dos incisivos foi também para SAIN ${ }^{185}$ o fator de maior peso na decisão entre tratar com ou sem extrações dentárias a má oclusão de Classe II. Resultados semelhantes foram encontrados por BISHARA; CUMMINS; JAKOBSEN ${ }^{32}$, em 1995, que ao realizarem um estudo retrospectivo de pacientes portadores de Classe II, divisão 1, tratados na Universidade de lowa, observaram um maior grau de apinhamento e protrusão labial presente entre os casos tratados com extração.

A prevalência de extrações em ortodontia foi estudada por PECK; PECK ${ }^{156}$ (1979), WEINTRAUB et al. $^{213}$ (1989) e GOTTLIEB; NELSON; VOGELS ${ }^{88}$ (1990) que relataram uma prevalência média de $42,1 \%, 39 \%$ e $25 \%$ respectivamente. Porém, WEINTRAUB et al. ${ }^{213}$ ressaltaram a existência de uma extensa variação no percentual de casos tratados com extrações entre diferentes ortodontistas (5\% a 87\%). Esta variação foi também explicitada por RIBAREVSKI et al. ${ }^{170}$ que ao avaliarem as decisões de dez ortodontistas sobre a necessidade de extrações em sessenta pacientes portadores de Classe II, Divisão 1, concluíram que 0 nível de concordância intra-examinador foi moderado, porém o nível de concordância estabelecido entre os examinadores foi considerado baixo. Isto 
sugere que os ortodontistas estão fundamentando suas decisões em critérios que não são universalmente aplicados.

Portanto, os critérios que fundamentam as decisões sobre a necessidade ou não de extrações dentárias no tratamento ortodôntico não deveriam ser norteados ou influenciados por linhas de conduta extracionista ou não extracionista ${ }^{44,206}$, mas sim pela busca dos objetivos estéticos e funcionais. Além disso, BOWMAN ${ }^{44}$ e RUSHING et al. ${ }^{180}$ asseveraram que ambos os tratamentos, com e sem extrações, podem resultar em prejuízos à estética facial quando erroneamente aplicados.

Faz-se necessário lembrar que a polêmica envolvendo as extrações dentárias em ortodontia remonta ao início do século passado, quando Angle passou a condenar fervorosamente as extrações dentárias para a correção de problemas ortodônticos sob o argumento de que uma "oclusão normal" apenas poderia ser alcançada na presença de todos os dentes. Foi a partir das publicações de Charles Tweed nos anos de 1941; 1944; 1945 e 1952 que os objetivos do tratamento ortodôntico com extrações passaram a ser melhor compreendidos ${ }^{26,27}$. Contudo, as controvérsias relacionadas ao tratamento ortodôntico com extrações não se restringem apenas à decisão de se extrair ou não, elas também se estendem à escolha dos dentes a serem extraídos.

Segundo o relato de GOTTLIEB; NELSON; VOGELS ${ }^{88}$, em 1990, e KEIM et al. ${ }^{122}$, em 2002, a extração dos primeiros pré-molares superiores constitui o segundo protocolo de extrações mais utilizado em ortodontia $(20,2 \%)$, sendo inferior apenas ao protocolo de extrações dos 
quatros primeiros pré-molares (42,9\%). Uma possível explicação para esta diferença pode não estar no grau de eficiência de um ou outro protocolo de extração, mas sim na sua aplicabilidade, uma vez que a extração dos primeiros pré-molares superiores está estreitamente relacionada à correção da má oclusão de Classe II, enquanto a extração de quatro primeiros prémolares é o principal protocolo de extração aplicado aos casos de má oclusão de Classe $I^{47,64,124,148,181,214}$. Considerando que a prevalência da má oclusão de Classe I na população é significativamente maior do que a prevalência da má oclusão de Classe II é de se esperar que o protocolo de extrações de quatro pré-molares tenha uma aplicação mais freqüente.

Ao avaliar os protocolos de extrações mais comumente utilizados pelos ortodontistas, BAUMRIND et al. ${ }^{22}$, concluíram que as extrações de quatro pré-molares, dois pré-molares, três pré-molares e um incisivo inferior, foram, nesta ordem, os protocolos mais freqüentemente empregados.

Embora, a maioria dos autores tenha observado que 0 protocolo de extrações de quatro pré-molares é utilizado com maior freqüência do que a extração de dois pré-molares superiores, $\mathrm{PROFFIT}^{157}$, estudando a freqüência de extrações na Universidade da Carolina do Norte, observou que nas últimas três décadas a prevalência da extração de quatro pré-molares sofreu uma drástica redução, igualando-se à extração de dois pré-molares superiores, utilizada na correção das más oclusões de Classe II. Segundo o autor o protocolo de extrações de quatro pré-molares teria sido mais influenciado pelas freqüentes publicações sobre: (1) a correlação entre 
tratamento ortodôntico com extrações e danos ao perfil e à ATM; (2) a ausência de correlação entre a realização de extrações e a maior estabilidade do tratamento e (3) a ocorrência de mudanças técnicas e mecânicas em busca de tratamento sem extrações.

Em razão de existirem consideráveis divergências no tratamento da má oclusão de Classe II, sobretudo quanto à necessidade de se extrair dentes, e de quais dentes deveriam ser extraídos, supõe-se que tratamentos sem extrações e com diferentes protocolos de extrações surtam resultados substancialmente diversos, caso contrário não haveria fundamento para tais discordâncias. Considerando esta suposição, buscouse revisar na literatura publicações que caracterizassem estas diferentes formas de tratamento da má oclusão de Classe II.

\subsubsection{Implicações}

Ao discorrer sobre os princípios do tratamento com extrações, FRASER ${ }^{80}$, em 1956, ressaltou que existem muitos casos de má oclusão de Classe II nos quais o padrão facial e a forma do arco mandibular indicam que um melhor equilíbrio e uma maior estabilidade podem ser alcançados com a extrações de apenas dois pré-molares superiores. Nestas condições, os primeiros pré-molares superiores deveriam ser extraídos.

Em 1963, KESSEL ${ }^{124}$ discorreu sobre as extrações de dois prémolares superiores como um método racional para a correção da má oclusão de Classe II, sobretudo em pacientes com idade de 12 anos ou mais 
cujo potencial de crescimento tende a diminuir progressivamente. Segundo o autor, os ortodontistas se deparam freqüentemente com uma elevada proporção de más oclusões de Classe II com moderada discrepância esquelética, reduzida quantidade de apinhamento inferior, protrusão dos incisivos superiores e variável quantidade de sobremordida. Para KESSEL ${ }^{124}$, o tratamento das más oclusões de Classe II que se enquadram nestas características seria mais racional e eficiente se fosse realizado mediante a extração de dois pré-molares superiores. Esta abordagem imprimi ao tratamento as seguintes vantagens: 1) restabelecimento da harmonia facial por meio da retração dos dentes anteriores superiores; 2) correção favorável do overjet e do overbite; 3) menor esforço sobre as unidades de ancoragem posterior; 4) maior favorecimento à erupção dos segundos e terceiros molares superiores e 5) menor necessidade de utilização de elásticos de Classe II, reduzindo a aplicação de forças e movimentações no arco inferior.

Por outro lado, RUNGE; SADOWSKY ${ }^{179}$ (1988), ressaltaram que quando o tratamento da má oclusão de Classe II requer a extração de quatro pré-molares podem surgir dificuldades em se obter uma correção satisfatória. Se os incisivos inferiores são excessivamente retraídos, é difícil e, por vezes, impossível corrigir o trespasse horizontal, sendo que a perda de ancoragem no arco superior complica ainda mais a correção ânteroposterior da má oclusão.

Em concordância com este pensamento BRYK; WHITE ${ }^{47}$, em 2001, afirmaram que no tratamento da má oclusão de Classe II, a extração 
de pré-molares inferiores deve ser evitada sempre que possível. Restrições ainda maiores a este protocolo de tratamento ocorrem quando o paciente apresenta um reduzido potencial de crescimento. Segundo o autor, as extrações de dois pré-molares superiores constituem uma excelente alternativa para a correção desta má oclusão, visto que esta abordagem permite que uma relação de Classe I dos caninos e uma boa intercuspidação dos dentes posteriores seja freqüentemente alcançada ${ }^{160}$.

A importância da ancoragem no tratamento da má oclusão de Classe II foi também ressaltada por JANSON et al. ${ }^{113}$, em 2004, que ao comparar os resultados oclusais provenientes do tratamento da Classe II com extração de dois e quatro pré-molares concluíram que a extração de dois pré-molares superiores apresentou resultados mais satisfatórios quanto ao valor final do IPT (índice de prioridade de tratamento), posicionamento ântero-posterior final dos caninos, quantidade final de sobressaliência e quantidade final de sobremordida. JANSON et al. ${ }^{113}$ ressaltam em seu estudo que o protocolo de extração de dois pré-molares superiores favorece a correção da má oclusão de Classe II, requerendo uma menor colaboração do paciente em utilizar reforços de ancoragem.

Reconhecidamente, a falta de cooperação do paciente na correção da má oclusão de Classe II com extração de quatro pré-molares superiores pode levar a resultados bastante insatisfatórios. JANSON et al. ${ }^{115}$, em 2003, relata um caso de má oclusão de Classe II que após ser tratado com extração de quatro pré-molares, apresentava ao final do tratamento a mesma discrepância ântero-posterior do início. O caso foi 
retratado com a extração de mais dois pré-molares superiores e finalizado satisfatoriamente. A necessidade de múltiplas extrações foi também relatada por ANDERSON ${ }^{6}$, em 1975, como uma conduta capaz de prover resultados satisfatórios quando a extração de quatro pré-molares é insuficiente para fornecer o espaço necessário à correção da má oclusão de Classe II, sobretudo quando o paciente apresenta problemas esqueléticos, ausência de crescimento, falta de cooperação, apinhamento severo, e mordida aberta.

Os melhores resultados na correção da discrepância ânteroposterior, obtidos a partir da extração assimétrica em casos de Classe II, Subdivisão, constituem, segundo JANSON et al. ${ }^{114}$, um outro exemplo de que a manutenção da relação molar presente no início do tratamento facilita a correção da má oclusão, diminuindo a necessidade de cooperação do paciente. A dificuldade de se corrigir a relação molar constitui segundo TURBILL; RICHMOND; WRIGHT ${ }^{201}$, (2001); ROBB et al. ${ }^{175}$ (1998) e VIG et al. $^{207}$ (1998) um fator que dificulta e prolonga o tratamento ortodôntico, da má oclusão de Classe II.

Um outro fator que contribui para a correção da discrepância ântero-posterior no tratamento da Classe II é o crescimento mandibular. Para PAQUETTE; BEATTIE; JHONSTON ${ }^{155}$ (1992), a correção total da relação molar de Classe II em pacientes adultos ocorre em menor escala quando comparado ao mesmo tipo de correção em pacientes adolescentes. Isso se deve ao fato de que em pacientes adultos não se pode contar com o crescimento da mandíbula para ir de encontro ao movimento distal dos molares superiores. Em conformidade com este pensamento, VADEN; 
HARRIS; BEHRENTS ${ }^{205}$, em 1995, afirmaram que a correção da relação molar de Classe II num paciente adulto conta exclusivamente com a movimentação dentária ${ }^{160}$, enquanto no adolescente a correção da relação molar ocorre pelo somatório de movimentação dentária e crescimento mandibular ${ }^{72}$.

Detalhando um pouco mais este mecanismo de correção, HARRIS; DYER; VADEN ${ }^{101}$ (1991), relataram que o processo normal de crescimento, aliado à perda de ancoragem, constituem os principais responsáveis pelo deslocamento do molar superior para baixo e para frente durante o tratamento da Classe II com extração de quatro pré-molares. Na adolescência esta perda de ancoragem do molar superior poderá, em certo grau, ser compensada pelo molar inferior em razão do crescimento mandibular e do movimento ortodôntico de mesialização. Porém na fase adulta não é permitida qualquer perda de ancoragem do molar superior, uma vez que o único mecanismo auxiliar à correção da relação molar é o espaço disponível no arco inferior para a mesialização dos molares. Quando uma maior mesialização do molar inferior é desejada, a extração de segundos pré-molares inferiores pode auxiliar neste objetivo ${ }^{182}$. Quanto à posição do molar superior, VADEN; HARRIS; BEHRENTS ${ }^{205}$, em 1995, alertam para o fato de que ao tratar um paciente adulto é mais fácil manter o molar superior na mesma posição do pré-tratamento do que num paciente adolescente.

Contudo, quando a má oclusão de Classe II é tratada sem extrações nenhum espaço torna-se disponível no arco inferior para mesialização ortodôntica do molar, ressaltando a importância do crescimento 
mandibular na correção da relação molar. Esta importância foi constatada por HUBBARD; NANDA; CURRIER ${ }^{109}$, em 1994, que ao tratarem, sem extrações, uma amostra de pacientes com má oclusão de Classe II, usando AEB com tração cervical, observaram que o crescimento da mandíbula é um relevante fator na correção da relação molar.

A dificuldade do tratamento da Classe II sem extrações, utilizando-se AEB ou Bionator, foi reportada em 2002 por JACOBS; SAWAENGKIT ${ }^{111}$. De acordo com estes autores o sucesso da correção da Classe II sem extrações está altamente relacionado ao grau de severidade da má oclusão e de cooperação do paciente ${ }^{16}$. Os resultados demonstraram que apenas $57 \%$ de sucesso deve ser esperado com este protocolo de tratamento para os paciente com uma má oclusão de 1/2 Classe II. Contudo este percentual de sucesso diminui consideravelmente (40\%) quando a severidade da má oclusão se apresenta acima de 1/2 Classe II.

Valendo-se destes mesmos aparelhos, um percentual semelhante de sucesso no tratamento da Classe II foi relatado por WHEELER et al. $^{216}$ em 2002. Segundo os autores $55 \%$ dos pacientes que apresentavam uma má oclusão de Classe II completa ao início do tratamento mostraram correção satisfatória. Além disso, WHEELER et al. ${ }^{216}$ também concluíram que o grau de severidade da má oclusão e de cooperação do paciente ${ }^{16}$ constitui eficientes parâmetros para predizer a correção da relação molar.

Conforme já foi relatado ${ }^{101,155,205}$, o potencial de crescimento do paciente afeta consideravelmente o prognóstico do tratamento da má 
oclusão de Classe II. Portanto, pacientes adolescentes, com reduzido potencial de crescimento deveriam ser tratados com uma abordagem que fosse a mais eficiente possível, reduzindo a necessidade de cooperação e otimizando os resultados do tratamento. KESSEL ${ }^{124}$; BRYK; WHITE ${ }^{47}$; JANSON et al. ${ }^{114}$ e JANSON et al. ${ }^{113}$ concordam que a extração de prémolares superiores mantendo a relação molar inicial constitui uma forma de tratamento bastante eficiente e de menor necessidade de cooperação por parte do paciente. Segundo PROFFIT et al. ${ }^{161}$ (1992), os resultados oclusais e estéticos alcançados com a extração de dois pré-molares superiores são, em geral, satisfatórios, mesmo quando aplicado em adolescentes cujo crescimento residual não contribui significativamente para o tratamento. Porém, nos últimos anos, os resultados do tratamento ortodôntico com extrações de pré-molares têm sido questionados tanto no âmbito estético quanto funcional. A premissa de que a extração de pré-molares favorece o desenvolvimento de desordens temporomandibulares e compromete a estética facial, tem desestimulado este protocolo de tratamento. Para PROFFIT et al. ${ }^{161}$ (1992), a extração de apenas dois pré-molares superiores permanece como um excelente método para a correção da má oclusão de Classe II.

A efetividade deste método de correção da má oclusão de Classe II pode ser nitidamente visualizada pelos estudos de ANDREWS ${ }^{8}$. Em sua análise, o autor afirma que para cada milímetro de discrepância são necessárias 2 U.E. (unidades de espaço) para correção. Considerando que a má oclusão de Classe II completa apresenta $7 \mathrm{~mm}$ de discrepância de 
cada lado, perfazendo um total de $14 \mathrm{~mm}$, tornam-se necessárias $28 \mathrm{U}$. E. (unidades de espaço) para corrigir esta má oclusão. Quando se extrai dois pré-molares superiores obtemos, em média, $14 \mathrm{~mm}$ ou 14 U.E. (7 mm de cada lado), sem que haja necessidade de qualquer colaboração do paciente com o uso de aparelhos. Desta forma restam 14 U.E. a serem obtidas com o auxílio da ancoragem e do crescimento, caso ainda exista potencial. Aplicando este mesmo raciocínio para a correção da má colusão de Classe II sem extrações, fica evidente que as 28 U.E. necessárias à correção da Classe II deverão ser obtidas integralmente com o auxílio do crescimento e do uso de aparelhos que disponibilizem estas unidades de espaço (AEB e elásticos de Classe II), necessitando uma maior colaboração do paciente para o sucesso do tratamento. Caso não haja potencial de crescimento, a correção da má oclusão de Classe II, sem extrações, torna-se ainda mais difícil e vinculada à cooperação do paciente.

No intuito de eliminar ou diminuir a necessidade de cooperação do paciente durante o tratamento da má oclusão de Classe II, sem extrações, criou-se uma variedade de aparelhos fixos (Distal Jet, Pendulum, Jones Jig, etc.), destinados a distalizar os dentes posteriores e corrigir a relação molar ${ }^{145}$. RUNGE; MARTIN; BUKAI. ${ }^{178}$, em 1999, e KELES; SAYINSU ${ }^{123}$, em 2000, constataram que estes dispositivos distalizadores promovem a movimentação dos molares superiores em direção posterior, dispensando a necessidade de cooperação do paciente. Contudo, efeitos negativos desta mecânica foram evidenciados e devem ser ressaltados. A perda de ancoragem com mesialização e angulação dos pré-molares, a 
projeção dos incisivos superiores, o aumento da sobressaliência e, ainda, o aumento da altura facial anterior e a angulação distal da coroa dos molares são efeitos freqüentemente indesejáveis, mas que no entanto devem ser esperados desta modalidade de tratamento. Além disso, a classificação dos referidos aparelhos como um dispositivo que elimine a necessidade de cooperação do paciente é questionável, mesmo porque, segundo GIANELLY; BEDNAR; DIETZ ${ }^{85}$, (1991), GIANCOTTI ${ }^{84}$, (2000) e GHOSH; NANDA $^{83}$ (1996), após a utilização destes aparelhos é necessário posicionar as raízes dos molares para distal, utilizando-se um AEB com força posterior e superior. Deve-se também considerar que para estabilizar e/ou conter os resultados obtidos faz-se necessária a aplicação de aparelhos removíveis como o Bionator, Ativador, AEB cuja ação depende fundamentalmente da colaboração do paciente.

Além disso, de acordo com a revisão de literatura realizada por ATHERTON; GLENNY; O'BRIEN ${ }^{11}$, em 2002, durante a correção da má oclusão de Classe II, a máxima quantidade de distalização obtida dos molares, seja com AEB ou com molas é, em geral, insuficiente para corrigir a relação molar. Se uma correção total é requerida, então algum movimento mesial do molar inferior deverá ocorrer para viabilizá-la.

Uma vez que a realização de extrações no tratamento ortodôntico sempre traz à tona questões ainda controvertidas na literatura, fez-se uma breve revisão sobre estes principais tópicos. 


\subsubsection{A correção e a estabilidade do apinhamento ântero-inferior}

O protocolo de tratamento da Classe II com extração de dois pré-molares superiores e sem extrações têm em comum o fato de ambos não envolverem extrações no arco inferior. Sendo assim, torna-se claro que uma das maiores limitações da aplicação destas duas formas de tratamento é o grau de apinhamento e/ou protrusão presentes neste arco.

De acordo com DEANGELIS ${ }^{64}$, (1973) e ACKERMAN; PROFFIT $^{1}$, (1997) a tolerância de adaptação dos tecidos moles e do periodonto, sem afetar o equilíbrio da face, é de 2 a 3mm de expansão do arco mandibular. Com referência específica ao periodonto, ALLAIS; MELSEN $^{5}$ (2003) ressaltaram que um aumento médio de 3,4 mm no comprimento do arco, obtido pela inclinação controlada dos incisivos, não causa danos ao periodonto na maioria dos pacientes.

A expansão rápida da maxila, seguida pela desinclinação dos dentes inferiores posteriores foi relatada por ADKINS; NANDA; CURRIER ${ }^{2}$ (1990) como uma forma alternativa para se evitar a extração no tratamento ortodôntico. Segundo os autores, esta expansão pode acontecer naturalmente como um resultado do redirecionamento das forças oclusais aplicadas aos dentes inferiores pelo arco superior expandido.

Porém, em alguns casos o grau de apinhamento é tal que o alinhamento dos dentes leva a uma expansão dos arcos que ultrapassa os limites considerados como aceitáveis. Nestas situações ainda se pode fazer uso das técnicas de desgaste interproximal que envolve a redução da 
espessura do esmalte nas faces proximais dos dentes, sobretudo dos posteriores, provendo um espaço adicional considerável (aproximadamente 8mm), segundo STROUD; ENGLISH; BUSCHANG ${ }^{194}$ (1998) e SHERIDAN; HASTINGS $^{190}$ (1992).

Uma vez corrigido o apinhamento, a estabilidade desta correção tem sido objeto de vários estudos. Para BOLEY et al. $^{42}$ (2003); BLAKE; BIBBY ${ }^{40}$ (1998) e ROSSOUW et al. ${ }^{177}$ (1993) a mudança na posição dos incisivos; as alterações na forma e no comprimento do arco e a mudança na largura intercaninos são variáveis que podem contribuir com a estabilidade da correção realizada. Porém, sabe-se que nenhuma destas variáveis, analisadas clinicamente, radiograficamente ou em modelos de gesso, são capazes de prognosticar a estabilidade do tratamento, tornando o grau de apinhamento no período pós-contenção uma condição totalmente imprevisível e independente da severidade inicial da má olcusão ${ }^{133136,220}$.

\subsubsection{O tempo de tratamento}

Tem-se demonstrado na literatura que um dos fatores capazes de influenciar o tempo de tratamento, tornando-o mais longo, é a realização de extrações dentárias ${ }^{54,77,105,150,201}$. Por outro lado, as más oclusões mais severas com uma acentuada discrepância ântero-posterior, têm-se relacionado à necessidade de extrações dentárias ${ }^{105,201}$.

Em conformidade com HOLMAN et al. ${ }^{105}$ e TURBILL; RICHMOND; WRIGHT ${ }^{201}$, GRACIANO ${ }^{93}$ (2003) constatou que más oclusões 
de Classe II tratadas com extrações apresentam um maior grau de discrepância ântero-posterior. Por outro lado, a necessidade de correção da relação ântero-posterior está relacionada como um maior tempo de tratamento $93,175,201,207$.

Um outro fator capaz de alterar o tempo do tratamento ortodôntico é o replanejamento do tratamento ${ }^{140,191}$. Segundo MARIA ${ }^{140}$, um elevado percentual de pacientes que iniciam o tratamento da Classe II sem extrações tem seu tratamento replanejado devido à tentativa mal sucedida de se corrigir a má oclusão de Classe II sem extrações. O período de tempo despendido nesta tentativa aumenta significantemente 0 tempo do tratamento.

A idade do paciente ao início do tratamento foi relatada por SHIA $^{191}$ como um fator potencialmente capaz de influenciar o tempo do tratamento. Segundo o autor, pacientes cujo tratamento é iniciado numa fase muito precoce tendem a apresentar um maior tempo de tratamento. Além disso, vários autores já demonstraram que o tratamento da má oclusão de Classe II, quando realizado em mais de uma fase, aumenta significantemente o tempo de tratamento $24,137,150,162,201,208$. Por outro lado, o tratamento de pacientes adultos pode apresentar graus de dificuldade maiores, o que também prolonga o tratamento ${ }^{191}$.

O grau de colaboração do paciente não afeta apenas os resultados, mas também o tempo de tratamento. Segundo CHEW; SANDHAM $^{54}$ e FINK; SMITH ${ }^{77}$, pacientes que faltam às consultas e quebram freqüentemente os aparelhos tendem a apresentar outras formas de não 
colaboração com o tratamento como, por exemplo, a falta de colaboração no uso de elásticos intermaxilares, AEB e quaisquer outros aparelhos removíveis.

\subsubsection{A retenção do terceiro molar}

De acordo com a revisão de literatura realizada por ATHERTON; GLENNY; O'BRIEN ${ }^{11}$, em 2002, durante a correção da má oclusão de Classe II, sem extrações, o molar superior é distalizado com o intuito de se corrigir a relação molar. Porém, nos tratamentos com extrações, algum movimento mesial dos molares pode ser esperado ${ }^{11,101,163,205}$.

CHIPMAN $^{55}$, em 1961, relata que a distalização dos molares superiores em pacientes com má oclusão de Classe II e reduzido potencial de crescimento pode ter efeitos indesejáveis na posição assumida pelos segundos e terceiros molares, caso não haja, na região da tuberosidade maxilar, uma quantidade de espaço suficiente para esta movimentação.

Ao tratar a má oclusão de Classe II sem extrações, por meio do aparelho pêndulo GHOSH; NANDA ${ }^{83}$ (1996), chamam a atenção para a necessidade de se acompanhar estes pacientes para avaliar o possível efeito da distalização dos molares, ocasionada pelo aparelho, sobre a impacção dos terceiros molares superiores. Este efeito foi então estudado anos mais tarde por KIM et al. ${ }^{126}$ (2003) que avaliou a associação entre a erupção dos terceiros molares e os tratamentos realizados com extrações de quatro pré-molares e sem extrações em 105 e 53 pacientes, 
respectivamente. Os autores concluíram que ocorreu uma significante redução na proporção de impacção dos terceiros molares superiores inferiores nos pacientes tratados com extrações, quando comparados aos pacientes tratados sem extrações. Segundo os autores a explicação destes resultados pode estar no aumento do movimento mesial dos molares, associado aos tratamentos com extrações, provendo uma maior quantidade de espaço para a erupção dos terceiros molares.

Ao comparar dois grupos de pacientes com má oclusão de Classe II, tratados sem extrações e com extrações de dois pré-molares superiores, PUTRICK ${ }^{163}$, em 2003, observou que o número de terceiros molares irrompidos e em função foi maior no grupo tratado com extrações. Portanto, pode-se esperar que a erupção dos terceiros molares seja mais favorecida nos casos em que a má oclusão de Classe II é tratada com extrações de pré-molares superiores do que quando o tratamento é realizado sem extrações.

\subsubsection{As alterações do perfil}

Segundo PROFFIT et al. ${ }^{161}$ (1992) e PROFFIT ${ }^{157}$ (1994), a premissa de que o tratamento ortodôntico com extrações causa danos ao perfil, tornando-o excessivamente retruído, tem desestimulado este protocolo de tratamento. Contudo, a literatura tem sido unânime em afirmar que os tratamento com e sem extrações podem resultar em benefícios ao perfil desde que um correto planejamento seja realizado ${ }^{18,33,45,69,223,225}$. Além 
disso, considerações especiais deveriam ser feitas durante o planejamento no que se refere às mudanças do perfil advindas do crescimento normal no período pós-tratamento ${ }^{34,225}$. Corroborando este pensamento, BOWMAN ${ }^{44}$ e RUSHING et al. ${ }^{180}$, afirmaram que ambos os tratamentos, com e sem extrações, podem resultar em prejuízos à estética facial quando erroneamente aplicados.

Buscando comparar os efeitos do tratamento ortodôntico sobre o perfil de pacientes tratados com e sem extrações BOWMAN; JOHNSTON $^{45}$, em 2000, observaram que os tratamentos realizados com extrações foram considerados esteticamente melhores pela avaliação de cirugiões-dentistas e de pessoas leigas, sendo que os resultados do tratamento da Classe II com extrações de apenas dois pré-molares superiores mostrou-se esteticamente superior em relação ao tratamento sem extrações e com extrações de quatro pré-molares. Portanto, é questionável a decisão de tratar a má oclusão de Classe II sem extrações sob a alegação de não danificar o perfil do paciente.

\section{4 Índices de avaliação}

A má oclusão tem interessado aos epidemiologistas durante 24 séculos desde que Hipócrates incluiu a condição de "dentes tortos" no seu sexto livro sobre epidemias. Entretanto, foi só em 1899 que Angle empenhou-se em classificar os tipos de más oclusões ${ }^{202}$. 
Os métodos usados para descrever e mensurar as más oclusões podem ser divididos em dois grandes grupos, os qualitativos e os quantitativos. Os métodos qualitativos foram os primeiros desenvolvidos ${ }^{198} \mathrm{e}$ registram cada traço da má oclusão, permitindo estimar sua prevalência numa dada população ${ }^{188}$. Como exemplo pode-se citar os métodos de ANGLE ${ }^{9}, \quad$ STALLARD ${ }^{192}, \quad$ MACCALL ${ }^{139}, \quad$ SCLARE $^{187}, \quad$ FISK $^{78}$, BJÖRK; KREBS; SOLOW ${ }^{39}$, etc. Os métodos quantitativos surgiram posteriormente, nas décadas de 50 e 60, e buscam mensurar a severidade das más oclusões $^{198}$.

Atualmente, vários índices oclusais, utilizados para mensurar as más oclusões, têm sido descritos na literatura norte-americana e alguns deles são aplicados para determinar o acesso à assistência pública na área ortodôntica, visto que neste país, e em vários países da Europa, uma significativa parcela dos tratamentos ortodônticos realizados está vinculada aos serviços de saúde pública. Além disso, mais recentemente estes índices estão sendo utilizados em pesquisas ${ }^{188}$.

Sendo assim, a aplicabilidade destes índices tem se tornado cada vez mais ampla. Segundo SHAW; RICHMOND; O'BRIEN ${ }^{188}$, os índices oclusais, de uma maneira geral, podem ajudar: (1) na distribuição mais coerente dos recursos destinados ao atendimento público, (2) na verificação e padronização dos tratamentos ortodônticos, (3) na melhor identificação das más oclusão que necessitam tratamento e (4) no consentimento por escrito do paciente nos casos em que a relação custo/benefício é desfavorável. O autor conclui que o índice PAR e INTO (índice da 
necessidade de tratamento ortodôntico) apresentam um satisfatório desempenho das funções acima descritas

A muito os modelos de estudo contribuem sobremaneira para o diagnóstico do tratamento ortodôntico. HAN et al. ${ }^{99}$ concluíram que somente a análise dos modelos de estudo (desconsiderando as informações da telerradiografia, panorâmica e fotografias) proveu informações para planejar adequadamente mais da metade (55\%) dos casos que foram analisados por cinco ortodontistas. Atualmente a aplicação dos índices oclusais aos modelos de estudo para avaliar o resultado ${ }^{4}$, a estabilidade ${ }^{220}$, a necessidade $^{94}$, e a complexidade ${ }^{61}$, dos tratamentos, tem ressaltado ainda mais a importância deste registro de diagnóstico na documentação ortodôntica.

Em geral, os índices são criados com propósitos específicos como a avaliação de resultado, complexidade, necessidade do tratamento ou da severidade ${ }^{104}$ das más oclusões. A utilização de um índice para um propósito diferente daquele inicialmente definido requer um estudo de validação do índice para esta nova finalidade.

O índice de prioridade de tratamento (IPT), elaborado por GRAINGER $^{94}$ (1967) teve como precursor o índice ESM (Estimativa da Severidade da Má oclusão) desenvolvido pelo mesmo autor no Burlington Orthodontic Research Center. O propósito inicial para o desenvolvimento do IPT foi determinar se o tratamento ortodôntico reduzia a severidade da má oclusão abaixo do nível de significância utilizado na saúde pública. Portanto, este índice foi elaborado no intuito de avaliar o grau de melhora decorrente 
do tratamento ortodôntico. Mais recentemente GHAFARI; LOCKE; BENTLEY ${ }^{82}$ (1989), ressaltaram que o IPT é um excelente indicador da presença de má oclusão.

Desde então, o índice IPT tem sido utilizado por outros autores, seja como um eficiente indicador da presença e severidade da má oclusão, seja como um confiável instrumento de avaliação da eficácia do tratamento ortodôntico $^{82,113,114}$.

Estudando a aplicação do IPT na dentadura mista TURNER ${ }^{202}$ (1990) observou que um dos fatores responsáveis pela menor validade do IPT neste estágio de desenvolvimento da oclusão era o grau de sobremordida. De fato, observando a tabela 3 da medida de sobremordida, utilizada por GRAINGER ${ }^{94}$ na elaboração do índice IPT pode-se confirmar que o grau de sobremordida varia com a idade e para o índice manter o seu grau de validade constante ele teria que ajustar os seus valores referenciais de acordo com a idade da amostra estudada.

De acordo com SHAW et al. ${ }^{189}$ (1991), um índice oclusal deve deter alguns requisitos importantes tais como fácil aplicação, boa reprodutibilidade, sensibilidade às mudanças oclusais para melhor ou pior, mínimo grau de subjetividade para aplicação, confiabilidade e validade para o fim a que se propõe. Estes requisitos, segundo RICHMOND et al. ${ }^{172}$ (1992), são preenchidos pelo índice PAR, criado em 1987 com o intuito de fornecer um único valor para todas as anomalias oclusais que podem ser encontradas em uma mesma má oclusão. Este índice, elaborado por um grupo de dez ortodontistas britânicos, foi julgado válido e confiável para 
avaliar os resultados oclusais do tratamento ortodôntico por um grupo de 74 examinadores, compostos por 48 especialistas em ortodontia e 26 clínicos gerais. Os autores concluíram que o índice PAR oferece uniformidade e padronização em avaliar os resultados do tratamento ortodôntico.

Os resultados do tratamento são estimados a partir da diferença calculada entre os valores dos índices obtidos nas fases pré e póstratamento, sendo que o valor numérico desta diferença é inversamente proporcional ao grau de melhora obtido com o tratamento ortodôntico ${ }^{172}$.

Com relação à utilização do índice PAR, RICHMOND et al. ${ }^{171}$ (1995) demonstrou que cirurgiões-dentistas podem ser facilmente treinados para aplicar satisfatoriamente este índice. Um dos aspectos não abordados por este índice é a oclusão funcional uma vez que os dados são obtidos exclusivamente da análise dos modelos $^{172}$.

Uma outra importante particularidade do índice PAR em relação aos demais índices é a forma de avaliar a relação ântero-posterior nos segmentos posteriores dos arcos. Sabe-se que o tratamento da Classe II, divisão 1 com extração de apenas dois pré-molares superiores é finalizado com os molares em relação de Classe II e os caninos em Classe I. Embora esta oclusão não apresente qualquer comprometimento funcional ${ }^{64,224}$, ela é penalizada pelos índices oclusais tais como o IO (índice oclusal) e o IPT (índice de prioridade de tratamento), devido à relação molar de Classe II presente ao final do tratamento. Porém, em razão do índice PAR não avaliar a relação molar, mas sim a intercuspidação dos segmentos 
posteriores do arco, a relação molar de Classe II não é considerada como uma característica preditiva de má oclusão ${ }^{48}$.

Posteriormente à sua elaboração e publicação, o índice PAR foi reavaliado por um grupo de onze ortodontistas Norte-Americanos quanto à sua eficácia em retratar o grau de severidade das más oclusões e o nível de complexidade do tratamento. A eficácia do índice foi considerada melhor quando novos pesos foram computados a cada um dos componentes do índice. Mediante estas modificações os autores puderam, então, concluir que o índice PAR constituiu um eficiente método de investigação da eficácia do tratamento ortodôntico a partir da avaliação das mudanças oclusais ${ }^{65}$. Certamente, a maior repercussão desta nova distribuição dos pesos foi a eliminação do apinhamento ântero-inferior como variável que contribui para a predição da severidade da má oclusão. A explicação para esta questão foi a facilidade em alinhar os dentes após a realização de extrações. Contudo, deve-se considerar que a necessidade de extrações já é um premonitório da severidade da má oclusão ${ }^{105,201}$, sem contar que em alguns casos a complexidade do tratamento aumenta mediante a realização de extrações, como, por exemplo, no tratamento da má oclusão de Classe II com indicação de extrações inferiores ${ }^{113}$.

Em 1990, HAMDAN; ROCK ${ }^{98}$ concluíram que o índice PAR teria a sua validade aumentada se as diferentes Classes de más oclusões fossem consideradas individualmente, recebendo pesos diferenciados e, portanto, mais adequados às características morfológicas de cada uma delas. Como, exemplo o autor ressalta que nas más oclusões de Classe II, 
Divisão 2 e Classe III, maior peso seria dado ao grau de sobremordida; nas más oclusões de Classe I o maior peso seria designado para a avaliação da linha média e na Classe II, Divisão 1 o trespasse horizontal continuaria a receber o maior peso.

Embora BUCHANAN et al. ${ }^{48}$ tenha observado que o 10 (índice oclusal de SUMMERS ${ }^{196}$ ) é igualmente confiável ao índice PAR na análise dos resultados do tratamento, TANG; WEI ${ }^{197}$ asseveram que o IO é inadequado à avaliação do resultado do tratamento ortodôntico, visto que ele não considera espaços residuais que podem perpetuar nos arcos dentários após o tratamento.

Uma vez que este estudo visa apenas a análise em modelos dos resultados oclusais do tratamento da Classe II, outros índices como o INTO $^{188}$ (Índice da Necessidade de Tratamento Ortodôntico) e o ICON ${ }^{61}$ (Índice da Complexidade Resultado e Necessidade) que incorporam em sua análise componentes estéticos, funcionais e de saúde dentária não serão considerados nesta revisão.

Considerando que o propósito de avaliação dos índices IPT e PAR são mais condizentes com as características do estudo ora empreendido e que eles apresentaram as menores limitações operacionais, estes dois índices serão aplicados aos modelos de estudo da amostra selecionada neste trabalho. 
A revisão da literatura demonstrou que o tratamento precoce da má oclusão de Classe II em duas fases não provê significativos benefícios quando comparado àquele realizado em uma única fase. Além disso, o resultado a longo prazo do tratamento ortopédico parece não diferir significativamente daquele obtido do tratamento com aparelhos fixos na fase de crescimento ativo. Sendo assim, é coerente a afirmação de que o tratamento da má oclusão de Classe II pode ser realizado a contento no período da adolescência, visando uma única intervenção que pode ou não envolver extrações dentárias. Considerando que as extrações podem variar entre dois e quatro pré-molares e que a comparação destes protocolos já demonstrou o maior grau de dificuldade em corrigir satisfatoriamente a má oclusão de Classe II a partir da extração de quatro pré-molares ${ }^{113}$, torna-se oportuna a comparação da eficiência do tratamento da Classe II realizado sem extrações e com extrações de dois pré-molares. 


$$
\text { PROPOSIÇÃO }
$$




\section{PROPOSIÇÃO}

O objetivo deste estudo é testar, a partir da análise em modelos, a seguinte hipótese nula: Não há diferença entre o grau de eficiência do tratamento ortodôntico da má oclusão de Classe II, realizado sem extrações e com extrações de dois pré-molares superiores. Para tanto, os resultados oclusais, o tempo de tratamento e o índice de eficiência destes dois protocolos serão comparados. 


\section{MATERIAL E MÉTODOS}




\section{MATERIAL E MÉTODOS}

\subsection{Material}

A seleção da amostra foi de caráter retrospectivo, realizada a partir dos registros de arquivo da Disciplina de Ortodontia da Faculdade de Odontologia de Bauru - Universidade de São Paulo.

Os critérios básicos para seleção da amostra incluíram as seguintes características:

- Má oclusão de Classe II completa bilateral, tratada sem extração ou com extração de dois pré-molares superiores;

- Presença de todos os dentes permanentes até os primeiros molares;

- Ausência de supranumerários;

- $\quad$ Ausência de dentes impactados;

- Ausência de anomalias quanto ao tamanho e/ou forma dos dentes;

- Tratamento com aparelho fixo pela mecânica Edgewise;

- Exclusão de casos tratados com cirurgia ortognática;

- Documentação ortodôntica completa; 
O critério utilizado para divisão da amostra em grupos 1 e 2 foi o protocolo de tratamento utilizado na correção da má oclusão de Classe II, portanto, os grupos foram assim diferenciados:

- Grupo 1 - tratamento da má oclusão de Classe II sem extrações;

- Grupo 2 - tratamento da má oclusão de Classe II com extrações de dois pré-molares superiores.

Todas as 3.592 documentações ortodônticas do arquivo da Disciplina de Ortodontia que preencheram estes critérios foram selecionados para compor a amostra, somando um total de 112 pacientes, divididos em dois grupos experimentais. O grupo 1, constituído por 43 pacientes com idade inicial média de 12,63 \pm 1,45 anos (idade mínima de 9,39 e máxima de 16,03), sendo 21 do gênero masculino e 22 do gênero feminino e o grupo 2 , composto por 69 pacientes com idade inicial média de 13,91 $\pm 2,71$ anos (idade mínima de 9,42 e máxima de 27,08), sendo 38 do gênero masculino e 31 do gênero feminino.

Em relação ao tipo de má oclusão, o grupo 1 apresentou 36 pacientes com Classe II, Divisão 1 e 7 pacientes com Classe II, Divisão 2, enquanto no grupo 2 esta distribuição foi de 51 e 18, respectivamente.

As dificuldades encontradas durante a correção da má oclusão de Classe II sem extrações determinaram o replanejamento do tratamento ortodôntico de 22 pacientes do grupo 2 (31,8\%). Considerando a 
possibilidade desta ocorrência influenciar os resultados e, principalmente, a duração do tratamento ${ }^{140,191}$, o grupo 2 foi subdividido em subgrupos A e B. Sendo assim, os 47 pacientes do grupo 2 cujo planejamento inicial previa extrações, passaram a constituir o subgrupo $2 A$. O subgrupo $2 B$ foi composto pelos 22 pacientes restantes, submetidos a replanejamento devido à tentativa mal sucedida de se corrigir a Classe II sem extrações.

O tratamento da má oclusão de Classe II realizado em duas fases, uma ortopédica e outra ortodôntica, ocorreu em 21 dos 43 pacientes do grupo 1 (48,8\%). Tendo em vista as controvérsias referentes à influência deste tipo de abordagem sobre os resultados e duração do tratamento da Classe II $^{19,24,67,90,137,162,176,199,222}$, os pacientes do grupo 1 foram divididos nos subgrupos $A$ e $B$. O subgrupo $1 \mathrm{~A}$, composto por 22 pacientes tratados em uma única fase e o subgrupo 1B constituído por 21 pacientes submetidos a tratamento ortopédico, previamente à fase ortodôntica.

\subsection{Métodos}

\subsubsection{Pastas ortodônticas}

As pastas ortodônticas relativas à amostra selecionada no arquivo da Disciplina de Ortodontia da Faculdade de Odontologia de Bauru, Universidade de São Paulo, foram utilizadas para a obtenção de alguns dados relevantes à realização deste trabalho. 
- Utilizou-se a ficha de dados cadastrais para o registro do nome completo dos pacientes, gênero e data de nascimento.

- A ficha do planejamento terapêutico inicial de cada paciente foi consultada quanto ao protocolo de tratamento proposto, sobretudo com referência à decisão de se extrair ou não os pré-molares superiores para a correção da má oclusão de Classe II.

- As fichas de procedimentos terapêuticos foram examinadas quanto às datas de início e término do tratamento. Estes dados, em conjunto com a data de nascimento do paciente, permitiram a determinação exata do tempo total de tratamento e da idade inicial do paciente.

- O relatório final do tratamento foi avaliado, principalmente, quanto ao cumprimento do planejamento inicial, identificando os casos em que as dificuldades encontradas durante 0 tratamento levaram ao replanejamento.

\subsubsection{Os índices oclusais IPT e PAR}

Os índices oclusais IPT e PAR foram utilizados para avaliar quantitativamente as relações oclusais intra e interarcos, observadas nos modelos de gesso pré e pós-tratamento dos 112 pacientes selecionados. 


\subsubsection{Cálculo do IPT ${ }^{94}$}

O cálculo do IPT é realizado a partir de uma tabela (Tabela 1) onde estão sintetizadas a principais características da oclusão a serem avaliadas, bem como os parâmetros necessários a esta avaliação.

\section{Relação Molar}

O primeiro passo para a obtenção deste índice é a classificação da relação molar que definirá tanto a coluna da tabela a ser utilizada, quanto a constante numérica a ser acrescentada ao valor final do índice. Uma vez que os critérios de seleção aplicados neste estudo requeriam a presença de uma má oclusão de Classe II completa, bilateral, ao início do tratamento, todos os pacientes selecionados foram inicialmente incluídos na primeira coluna da Tabela 1.

\section{Sobressaliência}

Uma vez definida a coluna apropriada ao tipo de má oclusão, o próximo passo constitui na mensuração em milímetros da quantidade de sobressaliência, tomando-se como referência a inicisal dos incisivos superiores em relação à face vestibular dos incisivos inferiores. A partir do valor desta medida pode-se estimar na Tabela 1 o escore correspondente.

\section{Sobremordida}

A quantificação da sobremordida foi realizada tomando como referência a quantidade de terços da coroa dos incisivos inferiores que se encontravam encobertos pelos incisivos superiores, obtendo-se na Tabela 1 o valor do escore correspondente. 


\section{Apinhamento}

O apinhamento total foi avaliado a partir da contagem do número de dentes que se encontravam deslocados ou girados em relação às suas posições ideais (apinhamento e/ou rotação). O somatório final obtido desta contagem foi utilizado para determinar na Tabela 1 o escore aplicado ao apinhamento.

\section{Mordida Cruzada}

A contagem total do número de dentes posteriores cruzados por lingual ou vestibular foi o critério utilizado para determinar, na Tabela 1, o escore referente a este item.

Uma vez obtidos os escores para todos os itens que compõem o índice, procedeu-se à soma total dos escores que foi ainda acrescida por uma constante de valor condizente como a relação molar inicialmente avaliada. Nos modelos pré-tratamento a constante que corresponde à relação molar teve sempre um mesmo valor, pois todos os pacientes apresentavam, neste estudo, más oclusões de Classe II completa bilateral ao início do tratamento, porém na análise dos modelos pós-tratamento a constante acrescentada variou de acordo com a relação molar observada ao término do tratamento. Cabe ressaltar que nos pacientes do grupo 2, submetidos à extração dos primeiros pré-molares superiores, a relação molar de Classe II presente ao final do tratamento foi considerada normal $^{47,64,113,114,124,148,181,214}$ e, portanto, classificada na mesma coluna da relação molar de Classe I. 
Baseando-se nos critérios descritos no texto e utilizando os valores de escores especificados na Tabela 1, calculou-se o índice IPT a partir do somatório total dos resultados parciais de seus componentes para cada um dos 224 pares de modelos. Sendo que o índice IPT foi denominado IPT inicial (IPTI) quando obtido a partir dos modelos pré-tratamento e, IPT final (IPTF) quando calculado nos modelos pós-tratamento.

\subsubsection{Cálculo do índice PAR $^{65,172}$}

O cálculo do índice PAR é realizado a partir da avaliação das cinco características oclusais que o compõem (oclusão posterior, sobressaliência, sobremordida, apinhamento e linha média), sendo que cada um destes componentes apresenta critérios de mensuração bem definidos (Tabela 2).

\section{Oclusão posterior}

A oclusão posterior é registrada separadamente para os lados esquerdo e direito. A relação dentária posterior é avaliada nos três planos do espaço e escores são dados às discrepâncias ântero-posterior, vertical e transversal de acordo com a Tabela 2. Em seguida, estes escores são somados e o valor final, multiplicado por dois.

\section{Sobressaliência}

São registradas as sobressaliências positivas e negativas, tomando-se como referência a face mais proeminente de qualquer incisivo. O valor medido da sobressaliência é em seguida transformado em escore de 
acordo com a Tabela 2 e multiplicado por 5. Durante esta medição a régua deve ser mantida paralela ao plano oclusal e radial à linha do arco.

\section{Sobremordida}

A sobremordida é registrada em relação à proporção da coroa dos incisivos inferiores que se encontra recoberta pelos incisivos superiores, tomando-se como referência o dente com maior sobreposição. Em casos de mordida aberta avalia-se em milímetros o grau de sua severidade. O escore é dado de acordo com a Tabela 2 e multiplicado por 3 .

\section{Linha média}

Registra-se a discrepância da linha média em relação aos incisivos centrais inferiores, sendo que o grau de desvio determina um escore que deve ser multiplicado por 3 (Tabela 2).

\section{Apinhamento}

O apinhamento é registrado apenas para a região ânterosuperior dos arcos dentários ${ }^{65}$. As características oclusais mensuradas neste item incluem apinhamento, espaçamento e dentes impactados sendo que as medidas são tomadas tendo como referência a menor distância dos pontos de contato dos dentes adjacentes. Em seguida, estas medidas são transformadas em escores de acordo com os critérios definidos na Tabela 2 e, então, somados. Um dente é considerado impactado quando o espaço a ele destinado for menor do que $4 \mathrm{~mm}$.

Utilizando-se os critérios descritos no texto e os valores de escores especificados na Tabela 2, calculou-se o índice PAR a partir do 
somatório total dos resultados parciais de seus componentes para cada um dos 224 pares de modelos. Sendo que o índice PAR foi denominado PAR inicial (PARI) quando obtido a partir dos modelos pré-tratamento e, PAR final (PARF) quando calculado nos modelos pós-tratamento.

Uma vez que os índices IPT e PAR são obtidos por meio da aplicação de escores que classificam numa escala ordinal a mensuração das relações dentárias intra (apinhamento) e interarcos (sobremordida, sobressaliência, mordida cruzada) a partir de um valor 0 de normalidade, quanto maior o valor numérico destes índices maior será o desvio da oclusão analisada em relação à normalidade.

A diferença entre os valores inicial e final dos índices IPT (DIFIPT) e PAR (DIFPAR) foi calculada para expressar a quantidade de melhora decorrente do tratamento. A partir desta medida obteve-se, também, os percentuais de melhora expressos pelos índices IPT (PCIPT) e PAR (PCPAR) $)^{13,30,172,173}$. Todas as medidas iniciais e finais referentes à quantidade de trespasse horizontal, vertical, apinhamento e desvio da linha média, foram obtidas nos modelos pré e pós-tratamento utilizando-se um paquímetro da marca $M A U B^{1}$ capaz de imprimir às medidas realizadas uma precisão de até $0,1 \mathrm{~mm}$.

\footnotetext{
${ }^{1}$ FWP, Maub, Polland
} 


\subsubsection{O índice de eficiência do tratamento (IET)}

Considerando que a eficiência representa a obtenção dos melhores rendimentos com um mínimo dispêndio de tempo, o grau de eficiência do tratamento foi avaliado a partir de um índice definido pela razão entre o percentual de melhora (PCIPT ou PCPAR) e o tempo de tratamento em meses, sendo expresso pela seguinte igualdade IETIPT = PCIPTITTRAT ou IETPAR = PCPARITTRAT. A partir desta relação matemática pode-se dizer que o percentual de melhora guarda uma relação direta com o índice de eficiência, enquanto o tempo de tratamento mantém uma relação inversa com este índice. Sendo assim, o valor do índice de eficiência aumenta na medida em que percentuais de melhora maiores se associam a tempos de tratamento menores. 


\subsubsection{Descrição das abreviaturas utilizadas para representar as variáveis estudadas}

Com o intuito de simplificar a manipulação e tabulação dos dados, as diversas variáveis consideradas neste estudo receberam abreviaturas que para seu melhor entendimento foram descritas da seguinte forma:

\begin{tabular}{|c|c|}
\hline ABREVIATURAS & DESCRIÇÃO \\
\hline 1. IPTI & Índice de prioridade de tratamento inicial \\
\hline 2. PARI & Índice PAR inicial \\
\hline 3. IPTF & Índice de prioridade de tratamento final \\
\hline 4. PARF & Índice PAR final \\
\hline 5. PCIPT & Percentual de redução do índice de prioridade de tratamento \\
\hline 6. PCPAR & Percentual de redução do índice PAR \\
\hline 7. IETIPT & Índice de eficiência do tratamento - IPT \\
\hline 8. IETPAR & Índice de eficiência do tratamento - Índice PAR \\
\hline 9. DIFIPT & Quantidade de redução do índice de prioridade de tratamento \\
\hline 10. DIFPAR & Quantidade de redução do índice PAR \\
\hline 11. IDADEI & Idade inicial \\
\hline 12. APINF & Quantidade de apinhamento inferior inicial \\
\hline 13. TTRAT & Tempo de tratamento total \\
\hline 14. AP & Relação ântero-posterior dos segmentos posteriores do arco \\
\hline 15. OVJ & Trespasse horizontal \\
\hline 16. OVB & Trespasse vertical \\
\hline 17. LM & Linha média \\
\hline 18. $\mathrm{MC}$ & Mordida cruzada \\
\hline 19. APINH & Apinhamento \\
\hline
\end{tabular}


Uma vez obtidos os valores iniciais e finais, a quantidade de melhora, o percentual de melhora e o grau de eficiência referente a ambos os índices para cada um dos 112 pacientes, passou-se à análise estatística dos dados.

\subsubsection{Análise Estatística}

\subsubsection{Erro do método}

O erro intra-examinador foi avaliado tomando-se novas medidas e calculando-se um novo índice para os modelos iniciais e finais de 30 pacientes de ambos os grupos, selecionados aleatoriamente, perfazendo um total de 60 pares de modelos. A fórmula proposta por DAHLBERG ${ }^{60}\left(\mathrm{Se}^{2}\right.$ $=\Sigma d^{2} / 2 n$ ) foi aplicada para estimar a ordem de grandeza dos erros casuais, enquanto os erros sistemáticos foram analisados pela aplicação dos teste $t$ pareado, de acordo com HOUSTON ${ }^{107}$ (1983).

\subsubsection{Análise estatística entre grupos e variáveis}

A compatibilidade dos grupos quanto à proporção dos tipos de má oclusão de Classe II (Classe II, Divisão 1 e 2) e dos gêneros foi avaliada pelo teste do Qui-Quadrado, enquanto o teste $t$ foi utilizado para avaliar a compatibilidade quanto à severidade inicial da má oclusão (IPTI e PARI); idade inicial (IDADEI) e quantidade de apinhamento inferior (APINF). 
$O$ teste $t$ foi aplicado às variáveis IPTF e PARF para comparação das características oclusais presentes ao final do tratamento entre os grupos 1 e 2. Comparação semelhante foi também realizada para as variáveis que expressavam a quantidade de melhora (DIFIPT; DIFPAR), o percentual de melhora (PCIPT; PCPAR) e o grau de eficiência do tratamento (IETIPT; IETPAR). Além disso, o teste $t$ foi também utilizado para comparar o tempo de tratamento (TTRAT) entre os grupos.

Tendo em vista que a diferença entre os grupos quanto à idade inicial pode influenciar nos resultados do tratamento $49,70,101,155,205$, compatibilizou-se os grupos quanto a esta variável e, em seguida, aplicou-se o teste $t$ para comparar o IPTI; PARI; IPTF; PARF; PCIPT e PCPAR.

Uma análise estatística descritiva foi realizada com o intuito de demonstrar a distribuição percentual dos pacientes nos grupos 1 e 2, de acordo com o valor das variáveis IPTF e PARF.

A hipótese de que o replanejamento do tratamento ortodôntico poderia influenciar na qualidade dos resultados e no tempo do tratamento $^{140,191}$ levou a crer que os 22 pacientes do grupo 2, submetidos a replanejamento (subgrupo 2B), poderiam ter influenciado a qualidade dos resultados e a duração do tratamento deste grupo, comprometendo, assim, a comparação entre os grupos 1 e 2. Para investigar esta hipótese, comparouse o grupo 1 (pacientes tratados sem extrações) e os subgrupos 2A (pacientes não replanejados tratados com extrações) e 2B (pacientes tratados com extrações após replanejamento do tratamento), por meio do teste de Análise de Variância (ANOVA). 
Assim como a idade inicial pode influenciar os resultados do tratamento, pensou-se que uma influência semelhante poderia também ocorrer em relação ao tempo de tratamento ${ }^{24,54,77,175,191,208}$. Para esclarecer esta dúvida, a idades iniciais do grupo 1 e subgrupo $2 \mathrm{~A}$ foram compatibilizadas e, então, o tempo de tratamento destes grupos foi comparado por meio do teste $t$. O subgrupo 2B, composto por pacientes replanejados, foi excluído desta comparação, uma vez que o replanejamento pode influenciar o tempo de tratamento.

Levando-se em conta as afirmações de que melhores resultados são obtidos quando a Classe II é tratada em duas fases ${ }^{19,90,176,222}$, investigou-se a hipótese de que os pacientes do grupo 1, tratados sem extrações e em duas fases (subgrupo 1B) apresentariam resultados melhores em relação àqueles tratados com extrações (grupo 2). Para tanto, comparou-se, por meio do teste $t$, os pacientes tratados sem extrações e em duas fases (subgrupo 1B) com aqueles tratados com extrações (grupo 2).

A correção em duas fases pode influenciar não apenas os resultados, mas também o tempo do tratamento. Considerando os relatos da literatura de que a correção da má oclusão de Classe II em duas fases prolonga o tratamento ${ }^{24,137,162,200}$, supôs-se que o tempo de tratamento do grupo 1 poderia ter sido influenciado pelos 21 pacientes deste grupo que foram submetidos a duas fases de tratamento (subgrupo 1B). Para avaliar a veracidade desta suposição comparou-se, por meio do teste $t$, os 22 pacientes do grupo 1, tratados em uma única fase (subgrupo 1A) com aqueles do grupo 2, não submetidos a replanejamento (subgrupo 2A). A 
possibilidade do replanejamento influenciar o tempo de tratamento determinou a exclusão dos pacientes replanejados (subgrupo 2B).

Considerando que os índices IPT e PAR são o resultado de um somatório de escores dados a cada uma das diversas características oclusais que compõem estes índices, propôs-se avaliar a influência de cada um destes componentes sobre o valor final dos índices. Porém, os diferentes pesos aplicados a cada um dos escores dados aos componentes destes índices inviabilizavam esta investigação. Uma vez que os pesos aplicados aos componentes do índice PAR podem ser mais facilmente removidos do que aqueles incorporados ao índice IPT, apenas o índice PAR foi selecionado para esta investigação. Sendo assim, o índice PAR foi desmembrado em seus diversos componentes e, em seguida, os pesos, inicialmente aplicados, foram removidos. A análise de regressão múltipla, aplicada aos diversos componentes do índice PAR permitiu, então, avaliar a influência de cada um dos componentes sobre o somatório final dos escores, enquanto o teste de Mann-Whitney foi utilizado para comparação intergrupos dos escores dados a cada um dos componentes do índice PAR. Deve-se ressaltar, ainda, que ao desmembrar o índice PAR em seus diversos componentes e remover os pesos referentes a cada um deles, observou-se que os valores fracionados dos escores não apresentavam, segundo o teste de Kolmogorov-Smirnov, uma distribuição normal, justificando a utilização do teste não paramétrico de Mann-Whitney .

Por fim, o teste de correlação de Pearson foi utilizado para avaliar o grau de correlação entre os percentuais de melhora (PCIPT e 
PCPAR) e os resultados oclusais (IPTF e PARF), retratados pelos índices IPT e PAR, enquanto o teste $t$ foi aplicado para comparar os percentuais de melhora demonstrados pelos índices IPT e PAR.

Todos os testes foram realizados com o programa STATISTICA ${ }^{2}$, adotando-se um nível de significância de 5\%.

${ }^{2}$ Statistica for Windows - Release 5.0 - Copyright StatSoft, Inc. 1995. 
TABELA 1 - Critérios de aplicação dos escores para os componentes do índice IPT ${ }^{94}$.

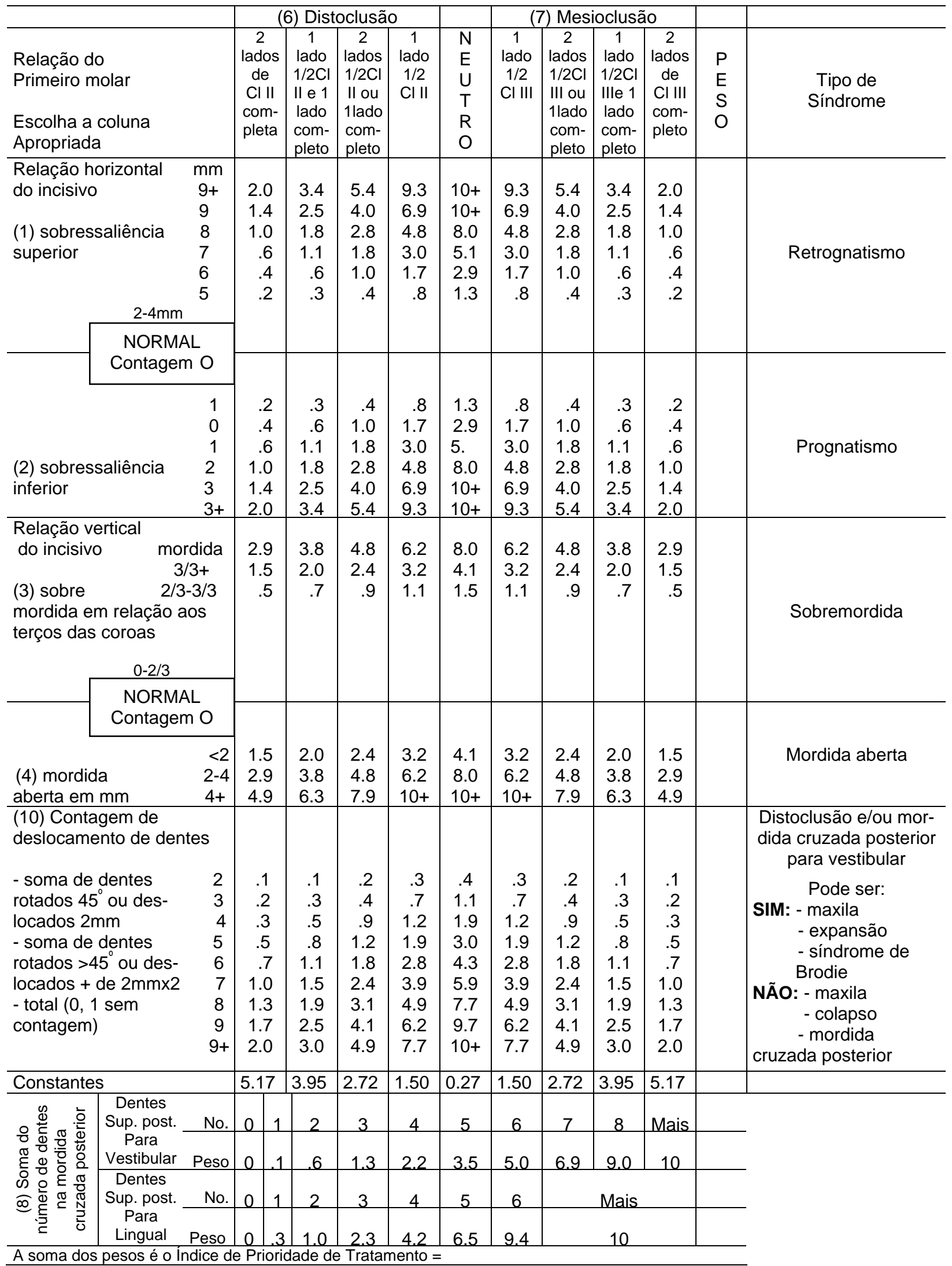


TABELA 2 - Critérios de aplicação dos escores para os componentes do índice $\mathrm{PAR}^{172}$.

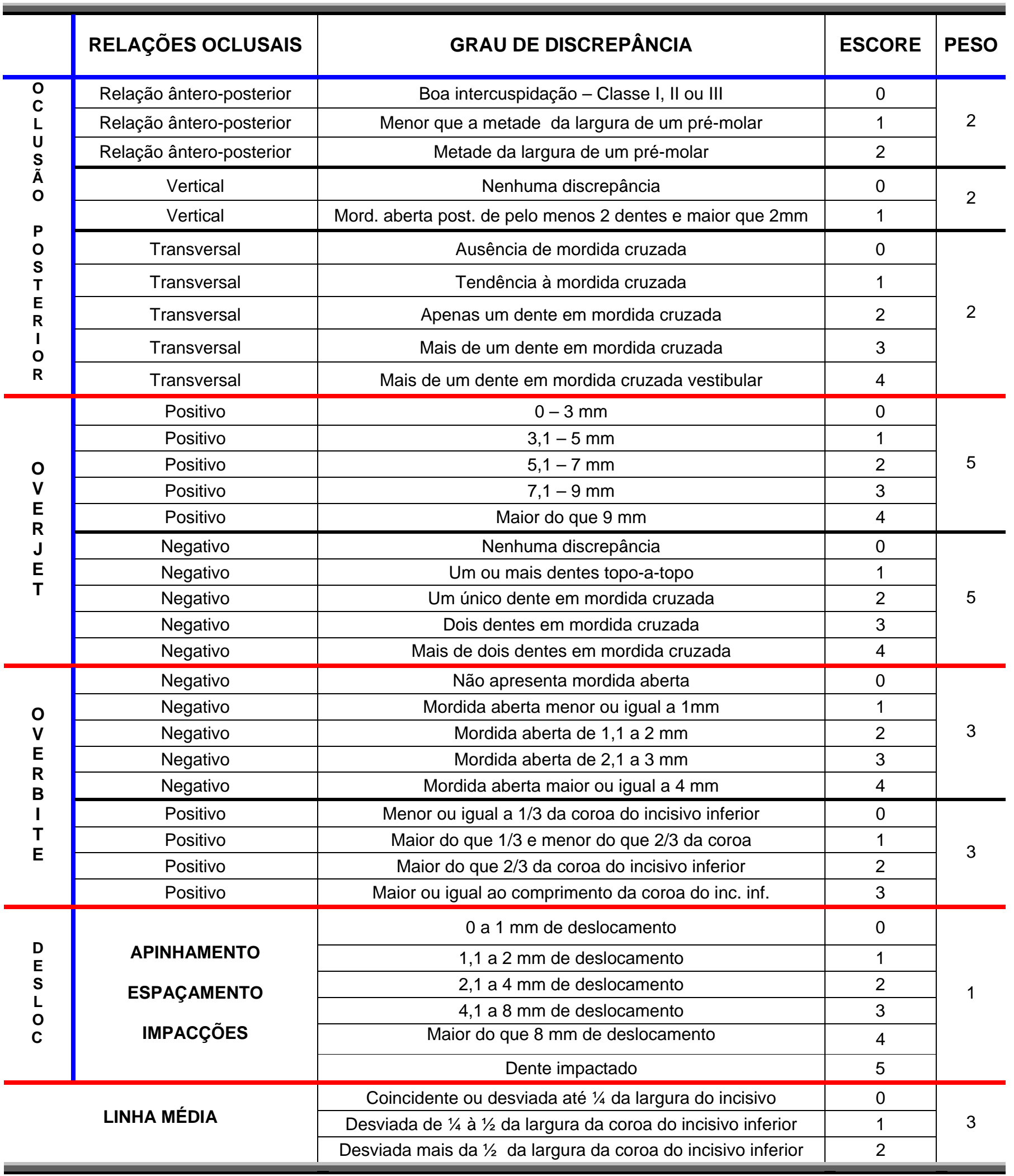




\section{RESULTADOS}




\section{RESULTADOS}

A tabela 3 apresenta os resultados da avaliação dos erros sistemáticos ${ }^{107}$ e casuais ${ }^{60}$, por meio da aplicação do teste $t$ pareado e da fórmula de Dahlberg, aplicados às variáveis IPTI; IPTF; PARI e PARF.

A compatibilidade dos grupos quanto à proporção dos tipos de má oclusão de Classe II (Classe II, Divisão 1 e 2) e proporção dos gêneros foi avaliada pelo teste do Qui-Quadrado (tabelas 4 e 5), enquanto a aplicação do teste $t$ avaliou a compatibilidade quanto à severidade inicial da má oclusão (IPTI e PARI) e idade inicial (tabela 6).

A tabela 6 também apresenta os resultados do teste $t$ para comparação dos grupos 1 e 2 quanto às variáveis IPTI; PARI; IDADEl; APINF; IPTF; PARF; DIFIPT; DIFPAR; PCIPT; PCPAR; IETIPT; IETPAR e TTRAT.

A tabela 7 apresenta os resultados da comparação, por meio do teste $t$, da qualidade de finalização do tratamento ortodôntico (IPTF; PARF; PCIPT e PCPAR) dos grupos 1 e 2, considerando a compatibilidade entre os grupos quanto à idade inicial (IDADEI).

As tabelas 8 e 9 mostram a distribuição quantitativa e percentual dos pacientes de ambos os grupos, segundo os valores do IPT e PAR final. 
A tabela 10 resume as comparações quanto aos resultados do tratamento (IPTF e PARF), tempo de tratamento (TTRAT) e eficiência do tratamento (IETIPT e IETPAR), realizadas por meio do teste de Análise de Variância (ANOVA), entre o grupo 1 (tratamento sem extrações) e os subgrupos 2A (tratamento com extrações, não replanejado) e 2B (tratamento com extrações, replanejado), considerando a compatibilidade entre o grupo e subgrupos quanto à severidade inicial da má oclusão (IPTI e PARI).

Os resultados apresentados na tabela 11 referem-se à comparação, por meio do teste t, do tempo de tratamento (TTRAT) entre o grupo 1 e o subgrupo 2A (tratamento com extrações, não replanejado) , levando em conta a compatibilidade dos grupos quanto à idade inicial (IDADEI).

Os resultados do teste $t$, apresentados na tabela 12 , referemse à comparação dos resultados (IPTF e PARF) e da eficiência do tratamento (IETIPT e IETPAR) entre o subgrupo 1B (tratamento sem extrações e em duas fases) e o grupo 2 (pacientes tratados com extrações).

A tabela 13 apresenta os resultados do teste $t$, aplicado na comparação do tempo (TTRAT) e da eficiência do tratamento (IETIPT e IETPAR) entre o subgrupo $1 \mathrm{~A}$ (tratamento sem extrações em uma fase) e o subgrupo 2A (tratamento com extrações, não replanejado), considerando a compatibilidade entre os subgrupos quanto à severidade inicial da má oclusão (IPTI e PARI). 
Na Tabela 14, os resultados da análise de regressão múltipla exprimem o grau de participação dos diversos componentes do índice PAR na variação do valor final deste índice, ao passo que a tabela 15 resume a comparação intergrupos dos escores dados a cada um dos componentes do índice PAR, realizada pelo teste de Mann-Whitney.

Na tabela 16, os resultados do teste de correlação de Pearson demonstram o grau de correlação entre os percentuais de melhora (PCIPT e PCPAR) e resultados oclusais (IPTF e PARF), retratados pelos índices IPT e PAR, enquanto a tabela 17 apresenta uma comparação entre os percentuais de melhora, demonstrados pelos índices IPT e PAR. 
TABELA 3 - Resultados do teste $t$ pareado e da fórmula de DAHLBERG ${ }^{60}$, aplicados às variáveis IPTI; IPTF; PARI e PARF para estimar os erros sistemáticos e casuais, respectivamente.

\begin{tabular}{|c|c|c|c|c|c|c|c|}
\hline \multirow{2}{*}{ VARIÁVEIS } & \multicolumn{2}{|c|}{$1^{\mathrm{a}} \mathrm{MEDIÇÃO} \mathrm{N}=30$} & \multicolumn{2}{|c|}{$2^{\mathrm{a}}$ MEDIÇÃO $\mathrm{N}=30$} & \multirow{2}{*}{ GL } & \multirow{2}{*}{$P$} & \multirow{2}{*}{$\begin{array}{c}\text { DAHLBER } \\
G\end{array}$} \\
\hline & $\overline{\mathrm{X}}$ & D.P. & $\overline{\mathrm{X}}$ & D.P. & & & \\
\hline IPTI & 7,71 & 1,01 & 7,67 & 0,89 & 29 & ,6808 & ,3123 \\
\hline IPTF & 1,09 & 1,15 & 1,06 & 1,15 & 29 &, 5840 & ,2345 \\
\hline PARI & 22,66 & 5,68 & 22,23 & 5,56 & 29 & 1079 & ,8062 \\
\hline PARF & 4,16 & 4,42 & 4,30 & 4,51 & 29 & ,4421 & ,5916 \\
\hline
\end{tabular}

TABELAS 4 e 5 - Resultados do teste Qui-Quadrado para avaliar a compatibilidade dos grupos quanto à proporção dos tipos de má oclusão e gênero.

\begin{tabular}{|c|c|c|c|}
\hline OCLUSÃO & CL II 1 & CL II 2 & TOTAL \\
\hline GRUPOS 1 & 36 & 7 & 43 \\
\hline G 2 & 51 & 18 & 69 \\
\hline Total & 87 & 25 & 112 \\
\hline$\chi^{2}=1,4696$ & $\mathrm{df}=1$ & \multicolumn{2}{|c|}{$\mathrm{p}=, 2254$} \\
\hline
\end{tabular}

\begin{tabular}{|c|c|c|c|}
\hline GÊNERO & M & $F$ & TOTAL \\
\hline G 1 & 21 & 22 & 43 \\
\hline G 2 & 38 & 31 & 69 \\
\hline Total & 59 & 53 & 112 \\
\hline$\chi^{2}=, 4131$ & df $=1$ & \multicolumn{2}{|c|}{$\mathrm{p}=, 5204$} \\
\hline
\end{tabular}


TABELA 6 - Resultados do teste $t$ independente, aplicado às variáveis estudadas nos grupos 1 e 2.

\begin{tabular}{|c|c|c|c|c|c|c|}
\hline \multirow{2}{*}{ VARIÁVEIS } & \multicolumn{2}{|c|}{ GRUPO1 $\quad N=43$} & \multicolumn{2}{|c|}{ GRUPO $2 \quad N=69$} & \multirow{2}{*}{ GL } & \multirow{2}{*}{$\mathrm{P}$} \\
\hline & $\bar{X}$ & D.P. & $\bar{X}$ & D.P. & & \\
\hline IPTI & 7,95 & 1,42 & 7,82 & 1,18 & 110 & ,5999 \\
\hline PARI & 24,32 & 7,67 & 23,95 & 7,40 & 110 & ,8008 \\
\hline IDADEI & 12,63 & 1,45 & 13,91 & 2,71 & 110 & ,0053 \\
\hline APINF &, 530 & 1,41 & ,695 & 1,25 & 110 & ,5188 \\
\hline IPTF & 1,58 & 1,72 & ,678 & ,726 & 110 & ,0001 \\
\hline PARF & 5,67 & 5,62 & 2,42 & 2,88 & 110 & ,0001 \\
\hline DIFIPT & 6,37 & 2,12 & 7,14 & 1,34 & 110 & ,0195 \\
\hline DIFPAR & 18,65 & 9,99 & 21,53 & 7,99 & 110 & ,0947 \\
\hline PCIPT & 79,78 & 22,71 & 91,32 & 9,23 & 110 & ,0002 \\
\hline PCPAR & 72,69 & 31,38 & 88,87 & 13,91 & 110 & ,0002 \\
\hline TTRAT - meses & 30,14 & 9,74 & 26,99 & 10,16 & 110 & , 1078 \\
\hline TTRAT - anos & 2,51 & ,812 & 2,24 & ,847 & 110 & , 1078 \\
\hline IETIPT & 2,69 & 1,43 & 3,67 & 1,33 & 110 & ,0003, \\
\hline IETPAR & 2,95 & 1,32 & 3,78 & 1,27 & 110 & ,0013 \\
\hline
\end{tabular}

TABELA 7 - Resultados do teste $t$, considerando a compatibilidade dos grupos 1 e 2 quanto à idade inicial (IDADEI).

\begin{tabular}{|c|c|c|c|c|c|c|}
\hline \multirow{2}{*}{ VARIÁVEIS } & \multicolumn{2}{|c|}{ GRUPO $1 \mathrm{~N}=36$} & \multicolumn{2}{c|}{ GRUPO 2 N = 58 } & \multirow{2}{*}{ GL } & \multirow{2}{*}{$\mathrm{P}$} \\
\cline { 2 - 5 } & $\overline{\mathrm{X}}$ & $\mathrm{D} . \mathrm{P}$. & $\overline{\mathrm{X}}$ & $\mathrm{D} . \mathrm{P}$. & & \\
\hline IPTI & 7,85 & 1,44 & 7,84 & 1,15 & 92 &, 9677 \\
\hline PARI & 24,08 & 7,93 & 23,91 & 7,18 & 92 &, 9151 \\
\hline IDADEI & 12,92 & 1,09 & 13,21 & 1,29 & 92 &, 2639 \\
\hline IPTF & 1,49 & 1,79 &, 684 &, 718 & 92 &, 0029 \\
\hline PARF & 5,27 & 5,80 & 2,37 & 2,88 & 92 &, 0017 \\
\hline PCIPT & 80,55 & 24,20 & 91,18 & 9,26 & 92 &, 0033 \\
\hline PCPAR & 73,78 & 33,33 & 88,94 & 14,28 & 92 &, 0030 \\
\hline
\end{tabular}


TABELA 8 - Distribuição percentual dos pacientes nos grupos $\mathbf{1}$ e $\mathbf{2}$, de acordo com o valor do IPTF.

\begin{tabular}{|c|c|c|c|c|c|c|c|c|}
\hline $\begin{array}{c}\text { IPT } \\
\text { FINAL }\end{array}$ & $\begin{array}{c}\text { QUANT. } \\
\text { G1 }\end{array}$ & $\begin{array}{c}\text { QUANT. } \\
\text { G2 }\end{array}$ & $\begin{array}{c}\text { CUMUL. } \\
\text { QUANT. } \\
\text { G1 }\end{array}$ & $\begin{array}{c}\text { CUMUL. } \\
\text { QUANT. } \\
\text { G2 }\end{array}$ & $\begin{array}{c}\text { PERCEN } \\
\text { T G1 }\end{array}$ & $\begin{array}{c}\text { PERCEN } \\
\text { T G2 }\end{array}$ & $\begin{array}{c}\text { CUMUL. } \\
\text { PERCEN } \\
\text { T G1 }\end{array}$ & $\begin{array}{c}\text { CUMUL. } \\
\text { PERCEN } \\
\text { T G2 }\end{array}$ \\
\hline, 00 & 9 & 21 & 9 & 21 & 20,93 & 30,43 & 20,93 & 30,43 \\
\hline, 27 & 9 & 19 & 18 & 40 & 20,93 & 25,53 & 41,86 & 57,97 \\
\hline, 37 & 0 & 3 & 18 & 43 & 0 & 4,34 & 41,86 & 62,31 \\
\hline, 57 & 2 & 1 & 20 & 44 & 4,65 & 1,44 & 46,51 & 63,76 \\
\hline 1,27 & 0 & 1 & 20 & 45 & 0 & 1,44 & 46,51 & 65,21 \\
\hline 1,50 & 4 & 17 & 24 & 62 & 9,30 & 24,63 & 55,81 & 89,85 \\
\hline 1,57 & 1 & 0 & 25 & 62 & 2,32 & 0 & 58,13 & 89,85 \\
\hline 1,77 & 2 & 5 & 27 & 67 & 4,65 & 7,24 & 62,79 & 97,10 \\
\hline 1,80 & 3 & 1 & 30 & 68 & 6,97 & 1,44 & 69,76 & 98,55 \\
\hline 1,97 & 1 & 0 & 31 & 68 & 2,32 & 0 & 72,09 & 98,55 \\
\hline 2,60 & 5 & 1 & 36 & 69 & 11,62 & 1,44 & 83,72 & 100,00 \\
\hline 3,40 & 1 & 0 & 37 & 69 & 2,32 & 0 & 86,04 & 100,00 \\
\hline 4,02 & 3 & 0 & 40 & 69 & 6,97 & 0 & 93,02 & 100,00 \\
\hline 4,55 & 1 & 0 & 41 & 69 & 2,32 & 0 & 95,34 & 100,00 \\
\hline 6,40 & 1 & 0 & 42 & 69 & 2,32 & 0 & 97,67 & 100,00 \\
\hline 6,67 & 1 & 0 & 43 & 69 & 2,32 & 0 & 100,00 & 100,00 \\
\hline
\end{tabular}

TABELA 9- Distribuição percentual dos pacientes nos grupos 1 e 2, de acordo com o valor da variável PARF.

\begin{tabular}{|c|c|c|c|c|c|c|c|c|}
\hline $\begin{array}{c}\text { PAR } \\
\text { FINAL }\end{array}$ & $\begin{array}{c}\text { QUANT. } \\
\text { G1 }\end{array}$ & $\begin{array}{c}\text { QUANT. } \\
\text { G2 }\end{array}$ & $\begin{array}{c}\text { CUMUL. } \\
\text { QUANT. } \\
\text { G1 }\end{array}$ & $\begin{array}{c}\text { CUMUL. } \\
\text { QUANT. } \\
\text { G2 }\end{array}$ & $\begin{array}{c}\text { PERCEN } \\
\text { T G1 }\end{array}$ & $\begin{array}{c}\text { PERCEN } \\
\text { T G2 }\end{array}$ & $\begin{array}{c}\text { CUMUL. } \\
\text { PERCEN } \\
\text { T G1 }\end{array}$ & $\begin{array}{c}\text { CUMUL. } \\
\text { PERCEN } \\
\text { T G2 }\end{array}$ \\
\hline 0 & 13 & 31 & 13 & 31 & 30,23 & 44,92 & 30,23 & 44,92 \\
\hline 2 & 3 & 12 & 16 & 43 & 6,97 & 17,39 & 37,20 & 62,31 \\
\hline 3 & 2 & 2 & 18 & 45 & 4,65 & 2,89 & 41,86 & 65,21 \\
\hline 4 & 4 & 11 & 22 & 56 & 9,30 & 15,94 & 51,16 & 81,15 \\
\hline 5 & 1 & 4 & 23 & 60 & 2,32 & 5,79 & 53,48 & 86,95 \\
\hline 6 & 4 & 2 & 27 & 62 & 9,30 & 2,89 & 62,79 & 89,85 \\
\hline 7 & 2 & 3 & 29 & 65 & 4,65 & 4,34 & 67,44 & 94,20 \\
\hline 8 & 2 & 1 & 31 & 66 & 4,65 & 1,44 & 72,09 & 95,65 \\
\hline 9 & 4 & 0 & 35 & 66 & 9,30 & 0 & 81,39 & 95,65 \\
\hline 10 & 0 & 2 & 35 & 68 & 0 & 2,89 & 81,39 & 98,55 \\
\hline 11 & 2 & 0 & 37 & 68 & 4,65 & 0 & 86,04 & 98,55 \\
\hline 12 & 0 & 1 & 37 & 69 & 0 & 1,44 & 86,04 & 100,00 \\
\hline 14 & 1 & 0 & 38 & 69 & 2,32 & 0 & 88,37 & 100,00 \\
\hline 15 & 1 & 0 & 39 & 69 & 2,32 & 0 & 90,69 & 100,00 \\
\hline 16 & 2 & 0 & 41 & 69 & 4,65 & 0 & 95,34 & 100,00 \\
\hline 18 & 1 & 0 & 42 & 69 & 2,32 & 0 & 97,67 & 100,00 \\
\hline 20 & 1 & 0 & 43 & 69 & 2,32 & 0 & 100,00 & 100,00 \\
\hline & & & & & & & & \\
\hline
\end{tabular}


TABELA 10 - Resultados da Análise de Variância e teste de Tukey aplicados ao grupo 1 e subgrupos $2 A$ e $2 B$.

\begin{tabular}{|c|c|c|c|c|c|c|c|c|}
\hline \multirow{2}{*}{ VARIÁVEIS } & \multicolumn{2}{|c|}{ GRUPO $1 N=43$} & \multicolumn{2}{|c|}{ SUBGRUPO 2A N =47 } & \multicolumn{2}{|c|}{ SUBGRUPO 2B N $=22$} & \multicolumn{2}{|c|}{ ANÁLISE DE VARIÂNCIA } \\
\hline & $\bar{X}$ & D.P. & $\bar{X}$ & D.P. & $\bar{x}$ & D.P. & $\mathrm{F}$ & $\mathrm{P}$ \\
\hline IPTI & $7,95^{a}$ & 1,42 & $7,80^{a}$ & 1,27 & $7,87^{a}$ & ,977 & 164 & ,8488 \\
\hline PARI & $24,32^{a}$ & 7,67 & $24,34^{a}$ & 7,47 & $23,13^{a}$ & 7,35 & ,223 & ,8002 \\
\hline IPTF & $1,58^{a}$ & 1,72 &, $649^{b}$ & 687 &, $741^{b}$ & ,815 & 7,42 & ,0009 \\
\hline PARF & $5,67^{a}$ & 5,62 & $2,80^{b}$ & 3,13 & $1,59^{b}$ & 2,08 & 8,82 & ,0002 \\
\hline $\begin{array}{l}\text { TTRAT } \\
\text { meses }\end{array}$ & $30,14^{a}$ & 9,74 & $23,60^{b}$ & 6,31 & $34,21^{a}$ & 12,93 & 11,37 & ,0000 \\
\hline $\begin{array}{c}\text { TTRAT } \\
\text { anos }\end{array}$ & $2,51^{a}$ & ,812 & $1,96^{b}$ &, 526 & $2,85^{a}$ & 1,07 & 11,37 & ,0000 \\
\hline IETIPT & $2,95^{a}$ & 1,32 & $4,14^{b}$ & 1,20 & $3,00^{a}$ & 1,08 & 12,44 & ,0000 \\
\hline IETPAR & $2,69^{a}$ & 1,43 & $3,95^{b}$ & 1,26 & $3,08^{a}$ & 1,28 & 10,31 & ,0000 \\
\hline
\end{tabular}

TABELA 11 - Resultados do teste $t$, considerando o grupo 1 e o subgrupo 2A compatíveis quanto à idade inicial (IDADEI).

\begin{tabular}{|c|c|c|c|c|c|c|}
\hline \multirow{2}{*}{ VARIÁVEIS } & \multicolumn{2}{|c|}{ GRUPO $1 \mathrm{~N}=36$} & \multicolumn{2}{c|}{ SUBGRUPO 2A N = 40 } & \multirow{2}{*}{ GL } & \multirow{2}{*}{$\mathrm{P}$} \\
\cline { 2 - 5 } & $\overline{\mathrm{X}}$ & $\mathrm{D} . \mathrm{P}$. & $\overline{\mathrm{X}}$ & $\mathrm{D} . \mathrm{P}$. & & \\
\hline IPTI & 7,85 & 1,44 & 7,82 & 1,28 & 74 &, 9154 \\
\hline PARI & 24,08 & 7,93 & 24,60 & 7,42 & 74 &, 7702 \\
\hline IDADEI & 12,92 & 1,09 & 13,40 & 1,26 & 74 &, 0805 \\
\hline IPTF & 1,49 & 1,79 &, 636 &, 671 & 74 &, 0064 \\
\hline PARF & 5,27 & 5,80 & 2,70 & 3,15 & 74 &, 0171 \\
\hline TTRAT - meses & 2,47 &, 804 & 1,92 &, 510 & 74 &, 0005 \\
\hline TTRAT - anos & 29,72 & 9,65 & 23,10 & 6,13 & 74 &, 0005 \\
\hline
\end{tabular}


TABELA 12 - Resultados do teste $t$, aplicado ao subgrupo 1B (tratamento em duas fases, sem extrações) e grupo 2 (tratamento com extrações).

\begin{tabular}{|c|c|c|c|c|c|c|}
\hline \multirow{2}{*}{ VARIÁVEIS } & \multicolumn{2}{|c|}{ SUBGRUPO 1B $\mathrm{N}=21$} & \multicolumn{2}{c|}{ GRUPO 2 } & \multirow{2}{*}{$\mathrm{N}=69$} & \multirow{2}{*}{$\mathrm{P}$} \\
\cline { 2 - 5 } & $\overline{\mathrm{X}}$ & $\mathrm{D} . \mathrm{P}$. & $\overline{\mathrm{X}}$ & $\mathrm{D} . \mathrm{P}$. & & \\
\hline IPTI & 8,02 & 1,25 & 7,82 & 1,18 & 88 & \multirow{2}{*}{, 4988} \\
\hline PARI & 26,42 & 7,84 & 23,95 & 7,40 & 88 & \multirow{2}{*}{, 1899} \\
\hline IPTF & 1,42 & 1,64 &, 678 &, 726 & 88 &, 0040 \\
\hline PARF & 4,95 & 5,75 & 2,42 & 2,88 & 88 & \multirow{2}{*}{, 0078} \\
\hline IETIPT & 2,84 & 1,31 & 3,78 & 1,27 & 88 &, 0042 \\
\hline IETPAR & 2,74 & 1,42 & 3,67 & 1,33 & 88 &, 0067 \\
\hline
\end{tabular}

TABELA 13 - Resultados do teste $t$, aplicado aos subgrupos 1A (tratamento em uma fase, sem extrações) e 2A (tratamento com extrações, sem replanejamento).

\begin{tabular}{|c|c|c|c|c|c|c|}
\hline \multirow{2}{*}{ VARIÁVEIS } & \multicolumn{2}{|c|}{ SUBGRUPO 1A N = 22 } & \multicolumn{2}{c|}{ SUBGRUPO 2A N=47 } & \multirow{2}{*}{ GL } & \multirow{2}{*}{ P } \\
\cline { 2 - 6 } & $\overline{\mathrm{X}}$ & $\mathrm{D} . \mathrm{P}$. & $\overline{\mathrm{X}}$ & $\mathrm{D} . \mathrm{P}$. & & \\
\hline IPTI & 7,88 & 1,59 & 7,80 & 1,27 & 67 &, 8098 \\
\hline PARI & 22,31 & 7,11 & 24,34 & 7,47 & 67 &, 2917 \\
\hline TTRAT- meses & 28,40 & 8,82 & 23,60 & 6,31 & 67 &, 0121 \\
\hline TTRAT- anos & 2,36 & 0,73 & 1,96 & 0,52 & 67 &, 0121 \\
\hline IETIPT & 3,05 & 1,36 & 4,14 & 1,20 & 67 &, 0012 \\
\hline IETPAR & 2,65 & 1,48 & 3,95 & 1,26 & 67 &, 0003 \\
\hline
\end{tabular}


TABELA 14 - Resultados da análise de regressão múltipla, considerando o valor final do índice PAR como variável dependente.

\begin{tabular}{|c|c|c|c|c|}
\hline VARIÁVEIS & $\mathrm{R}$ & $\mathrm{R}^{2}$ & $\mathrm{R}^{2}$ VARIAÇ̃̃o & $\mathrm{P}$ \\
\hline I. AP &, 857 &, 735 &, 735 &, 0000 \\
\hline II. OVJ &, 914 &, 836 &, 101 &, 0000 \\
\hline III. MC &, 961 &, 923 &, 086 &, 0000 \\
\hline IV. OVB &, 992 &, 984 &, 060 &, 0000 \\
\hline V. LM &, 996 &, 993 &, 008 &, 0000 \\
\hline
\end{tabular}

PARF $=0,07+1,02(A P)+0,97(O V J)+0,98(M C)+0,97(O V B)+1,01(L M)$.

TABELA 15 - Resultados do teste de Mann-Whitney, aplicado aos valores finais de cada um dos componentes do índice PAR, nos grupos 1 e 2.

\begin{tabular}{|c|c|c|c|c|}
\hline \multirow{2}{*}{ VARIÁVEIS } & GRUPO 1 N=43 & GRUPO 2 N=69 & \multirow{2}{*}{ Z } & P \\
\cline { 2 - 3 } & POSTO MÉDIO & $\begin{array}{r}\text { POSTO } \\
\text { MÉDIO }\end{array}$ & $-2,180$ &, 0292 \\
\hline AP & 64,97 & 51,21 & $-1,379$ &, 1679 \\
\hline OVJ & 61,86 & 53,15 & $-1,426$ &, 1536 \\
\hline OVB & 62,04 & 53,04 &,- 284 &, 7762 \\
\hline LM & 57,60 & 55,81 &,- 978 &, 3280 \\
\hline MC & 60,30 & 54,13 &,- 257 &, 7969 \\
\hline APINH & 55,48 & 57,11 & & \\
\hline
\end{tabular}


TABELA 16 - Resultados do teste de correlação aplicado às variáveis IPTF, PARF, PCIPT E PCPAR.

\begin{tabular}{|c|c|c|}
\hline VARIÁVEIS & PARF & PCPAR \\
\hline IPTF & $\mathrm{R}=, 878 \quad \mathrm{p}=, 000$ & $\mathrm{R}=-, 804 \quad \mathrm{p}=, 000$ \\
\hline PCIPT & $\mathrm{R}=-, 865 \quad \mathrm{p}=, 000$ & $\mathrm{R}=, 851 \quad \mathrm{p}=, 000$ \\
\hline
\end{tabular}

TABELA 17 - Resultados do teste $t$ independente aplicado às variáveis PCIPT e PCPAR.

\begin{tabular}{|c|c|c|c|c|c|c|}
\hline \multirow{2}{*}{ VARIÁVEL } & \multicolumn{2}{|c|}{ GRUPO IPT N $=112$} & \multicolumn{2}{|c|}{ GRUPO PAR N $=112$} & \multirow{2}{*}{ GL } & \multirow{2}{*}{ P } \\
\cline { 2 - 5 } & $\overline{\mathrm{X}}$ & D.P. & $\overline{\mathrm{X}}$ & D.P. & & \\
\hline $\begin{array}{c}\text { PCIPT } \\
\text { PCPAR }\end{array}$ & 86,89 & 16,71 & 82,66 & 23,53 & 222 &, 1220 \\
\hline
\end{tabular}




$$
\text { DISCUSSÃO }
$$




\section{DISCUSSÃO}

Com o intuito de proporcionar um melhor entendimento dos resultados obtidos e um maior discernimento sobre as variáveis envolvidas neste estudo, discutiu-se numa seqüência estratificada, a amostra utilizada, a metodologia aplicada e os resultados obtidos.

\subsection{A amostra utilizada}

A seleção da amostra foi realizada com o intuito de comparar dois diferentes protocolos de tratamento da má oclusão de Classe II. Para tanto, apenas pacientes apresentando uma má oclusão de Classe II tratada sem extrações ou com extrações de dois pré-molares superiores, foram considerados. Além deste, outros critérios estabelecidos para a seleção da amostra serão discutidos.

A presença de uma má oclusão de Classe II completa e bilateral permitiu que os grupos apresentassem ao início do tratamento uma igualdade quanto à severidade da discrepância ântero-posterior dos arcos. Esta igualdade entre os grupos constituiu parâmetro fundamental para avaliar a eficiência dos dois protocolos de tratamento considerados neste estudo, uma vez que o sucesso da correção da má oclusão de Classe II pode variar em função da severidade inicial da discrepância ânteroposterior $^{111,216}$.

Apenas pacientes submetidos a terapia ortodôntica corretiva foram incluídos na amostra. A razão para o estabelecimento deste critério foi 
a necessidade de preservação da compatibilidade entre os grupos, uma vez que no grupo submetido a extrações todos os pacientes foram compulsoriamente tratados com aparelho fixo. Caso não se estabelecesse esta compatibilidade entre os grupos, os resultados seriam severamente influenciados pela variável em questão, posto que os índices oclusais utilizados para avaliar a qualidade de finalização do tratamento ortodôntico em ambos os grupos quantificam não apenas o grau de correção da discrepância ântero-posterior, mas também as alterações ocorridas em outras relações oclusais como a sobremordida, sobressaliência, o alinhamento dentário, e a linha média, cujo total controle só pode ser obtido com a utilização do aparelho fixo.

Os principais tipos de aparelhos destinados à correção da má oclusão de Classe $\|^{31}$ foram considerados neste estudo, não constituindo critérios de exclusão. Sendo assim, pacientes tratados com aparelhos extrabucais (AEB), associados ou não a aparelhos funcionais, e elásticos de Classe II, foram indistintamente selecionados, desde que tivessem concluído o tratamento com aparelho fixo e mecânica Edgewise. O estabelecimento desta condição permitiu retratar com maior fidelidade os resultados comumente obtidos na correção da Classe II, visto que as mecânicas de Classe II consideradas são as mais freqüentemente utilizadas.

A presença de todos os dentes permanentes até os primeiros molares e a ausência de dentes supranumerários constituiu um critério para inclusão de pacientes na amostra visto que a perda de dentes permanentes, assim como a presença de dentes supranumerários, erupcionados ou não, 
pode interferir no desenvolvimento normal da oclusão, produzindo más oclusões cuja correção exige uma mecânica ortodôntica diferenciada, não contemplando o propósito deste estudo ${ }^{51,183,184}$.

Os casos com anomalias significativas quanto à forma e/ou tamanho dos dentes (macrodente, microdente, dente conóide) foram excluídos uma vez que poderiam aumentar o grau de complexidade do tratamento por uma razão inerente à anatomia dentária e não ao tratamento ortodôntico em $\mathrm{si}^{56,224}$. As pequenas discrepâncias do tamanho dentário, detectadas apenas pela Análise de Bolton, não foram consideradas neste estudo em razão de sua ocorrência não interferir significativamente nos resultados finais ${ }^{103,168}$. Deve-se ressaltar também que dentre os grupos de más oclusões de Angle, a má oclusão de Classe II apresenta a menor prevalência de discrepância do tamanho dentário ${ }^{10}$. Além disso, a ausência de fatores que favoreça uma maior ocorrência desta discrepância leva a crer que sua incidência entre os grupos estudados é semelhante.

Considerando meticulosamente todos os critérios já mencionados, uma amostra de 112 pacientes (43 do grupo 1 e 69 do grupo 2) foi selecionada a partir da investigação de 3.592 documentações ortodônticas provenientes dos registros de arquivo dos cursos de pósgraduação, lato e stricto sensu, e atualização da Disciplina de Ortodontia da Faculdade de Odontologia de Bauru. Admitindo-se que o percentual de incidência da má oclusão de Classe II de Angle seja de aproximadamente $30 \%{ }^{158}$ e que o total de documentações ortodônticas investigadas foi de 3.592, era de se esperar que a amostra selecionada fosse composta por um 
número bem maior de pacientes. Contudo, deve-se ponderar que os critérios estabelecidos para a seleção da amostra foram os responsáveis pela eliminação de um grande número de pacientes com esta má oclusão. Além disso, ressalta-se que a despeito dos esforços empregados para se obter os registros completos de todos os pacientes tratados na Disciplina, alguns deles não apresentavam uma documentação ortodôntica condizente com as necessidades específicas deste estudo.

O menor número de pacientes selecionados para compor o grupo 1 da amostra (43 pacientes) pode ter decorrido do maior grau de dificuldade que representa a correção da má oclusão de Classe II completa sem extrações, reduzindo, assim, a quantidade de casos com discrepância ântero-posterior severa, submetidos a este protocolo de tratamento $8,111,124,216$. Deve-se, ainda, ressaltar que um elevado percentual dos pacientes que iniciam o tratamento da Classe II completa sem extrações são posteriormente replanejados com extrações de dois pré-molares superiores $^{140}$, diminuindo ainda mais a quantidade destes tratamentos levados a termo sem a necessidade de extrações.

O grupo de pacientes tratados sem extrações foi dividido em subgrupos 1A (1 fase de tratamento) e 1B (2 fases de tratamento) de acordo com número de fases do tratamento. Considerou-se duas fases de tratamento os pacientes que por um período igual ou superior a 6 meses utilizaram apenas aparelhos ortopédicos como meio de correção da má oclusão inicial de Classe ${ }^{19}{ }^{19,222}$, sendo que o tempo médio de tratamento da fase ortopédica foi de 11,2 meses \pm 5,9 e a idade média deste subgrupo foi 
12,1 $\pm 1,33$ anos. Esta divisão do grupo 1 tornou-se necessária mediante a hipótese de que o subgrupo de pacientes tratados em duas fases (subgrupo 1B) poderia influenciar os resultados e o tempo do tratamento do grupo 1.

Os pacientes do grupo 2, tratados com extrações, foram também divididos em subgrupos A e B uma vez que 22 dos 69 pacientes pertencentes a este grupo tiveram seus tratamentos replanejados após a tentativa frustrada de correção da má oclusão de Classe II sem extrações. A possibilidade do replanejamento influenciar os resultados e, sobretudo, o tempo do tratamento determinou a divisão deste grupo.

\subsection{Metodologia}

A utilização de modelos de estudo como único meio de avaliação das características oclusais do paciente apresenta limitações diagnósticas, privando o profissional das análises clínica e radiográfica. Contudo, este é o registro de estudo que, sozinho, reúne a maior quantidade informações relacionadas ao diagnóstico e tratamento ortodôntico ${ }^{99}$. Além disso, tem-se demonstrado: 1) uma pobre associação entre as características oclusais observadas em modelos de estudo e a morfologia craniofacial avaliada nas telerradiografias $^{121}$ e 2) uma melhor predição dos resultados do tratamento ortodôntico por meio dos índices oclusais, obtidos dos modelos de estudo pré-tratamento, do que pelas variáveis cefalométricas, medidas nas telerradiografias iniciais ${ }^{125,143}$. O fato de que as 
características oclusais nem sempre refletem a morfologia craniofacial, foi evidenciado por PANCHERZ ${ }^{154}$ que observou características cefalométricas semelhantes ao comparar a Classe II, divisão 1 e 2, contrariando o difundido pensamento de que o maior overbite da má oclusão de Classe II, Divisão 2 está vinculado ao padrão esquelético mais horizontal (hipodivergente) desta má oclusão ${ }^{119}$. Somando-se a estes fatos, ACKERMAN $^{1}$ (1997) afirma que as decisões sobre a estética facial devem seguir o diagnóstico clínico ao invés do cefalométrico.

Portanto, depreende-se que a escolha da metodologia a ser empregada deve se basear, impreterivelmente, na proposição do trabalho. Se o propósito maior é avaliar as mudanças nas estruturas craniofaciais, então as telerradiografias são indispensáveis, porém se o objetivo se restringe ao estudo das alterações oclusais decorrentes do tratamento, provavelmente a utilização de telerradiografias laterais não trará significativos acréscimos ou elucidações ${ }^{116}$. Além disso, algumas características importantes da oclusão, tais como a quantidade de apinhamento e a relação transversal dos arcos, não poderão sequer, serem avaliadas por este método de investigação ${ }^{46}$.

Deve-se também ressaltar que o caráter retrospectivo deste estudo permitiu que todos os casos, condizentes com os critérios adotados, fossem selecionados. Portanto, se diferenças existiam entre os valores cefalométricos dos grupos, estas tiveram seus pesos no planejamento do tratamento. Além do mais, não está em discussão o mérito de cada planejamento, mas sim os resultados oclusais proporcionados. 
A obtenção de dados mais detalhados sobre a oclusão funcional ao término do tratamento ficou limitada pela característica retrospectiva deste estudo, sendo que as informações a este respeito ativeram-se aos registros constantes nos prontuários. Porém, a constatação de que a montagem em articulador dos modelos iniciais na posição mandibular de relação cêntrica não muda significativamente o planejamento do tratamento ${ }^{73}$, leva a crer que a realização deste mesmo procedimento, ao final do tratamento, não será mais proveitosa do que foi ao início. Além disso, a probabilidade de ocorrência de pequenos desvios funcionais ao final do tratamento tende a ser semelhante entre os grupos, não constituindo um fator de diferenciação entre eles.

Considerando todos os fatores já mencionados a respeito da metodologia aplicada, admitiu-se que a utilização dos modelos de estudo como material de pesquisa cumpre satisfatoriamente os objetivos deste estudo.

Foi baseado exclusivamente nas informações contidas em 120 modelos de oclusão normal que ANDREWS $^{7}$ relacionou as seis características oclusais que mais freqüentemente ocorriam, definindo-as como as seis chaves da oclusão normal. Este legado passou a representar um dos mais valiosos parâmetros para a obtenção de uma oclusão estática ideal, contudo, o ideal nem sempre é alcançado ao final do tratamento ortodôntico. Sendo assim, a utilização de índices oclusais que mensuram o quanto as relações oclusais desviam da normalidade ao final do tratamento constitui atualmente um importante instrumento de pesquisa sobre a eficácia 
dos diversos protocolos de tratamento ortodôntico utilizados para um mesmo $\operatorname{fim}^{4,30,113,114,125,143}$.

Uma vez que o principal propósito deste estudo foi comparar os resultados oclusais obtidos de dois diferentes protocolos de tratamento, os índices oclusais IPT e PAR foram selecionados dentre outros índices que permeiam a literatura pela comprovada validade que possuem em expressar quantitativamente uma determinada condição oclusal, pela confiabilidade e reprodutibilidade que imprimem aos resultados, por terem sido elaborados e largamente utilizados com o propósito de avaliar os resultados do tratamento ortodôntico e por serem de aplicação simples e objetiva $^{4,30,48,65,71,94,95,104,113,114,131,143,171173,188,189}$.

Além disso, os índices IPT e PAR proporcionam uma avaliação criteriosa não apenas dos resultados do tratamento, mas também do grau de severidade da má oclusão ao início do tratamento. Estes atributos permitiram investigar tanto a quantidade e o percentual de melhora obtidos em cada grupo ao final do tratamento, quanto a compatibilidade dos grupos em relação à severidade inicial da má oclusão $0^{13,30,65,113,172,173}$. Cabe ressaltar também que o processo de obtenção dos índices IPT e PAR envolve apenas as informações obtidas dos modelos de gesso ${ }^{94,171,172}$, haja vista que as avaliações clínicas exigidas em outros índices ${ }^{61,189}$ não condizem com o caráter retrospectivo deste estudo, conforme já foi explicitado.

O percentual de melhora, evidenciado pelos índices IPT e PAR, foi relacionado ao tempo de tratamento com o intuito de obter um índice capaz de expressar o grau de eficiência do tratamento. Este índice permitiu 
a mensuração de uma característica do tratamento que é freqüentemente comentada na literatura ${ }^{50,111,146}$, porém raramente avaliada acima da subjetividade de opiniões, visto que a eficiência do tratamento ortodôntico não se restringe à qualidade de finalização.

O índice $\mathrm{PAR}^{65}$ utilizado neste estudo não considera a presença de apinhamento ântero-inferior. Esta condição poderia influenciar os resultados obtidos caso os grupos estudados diferissem quanto a esta variável. Porém, a ausência de extrações no arco inferior em ambos os grupos acabou por refletir uma semelhança entre eles em relação ao grau de apinhamento observado no arco inferior (tabela 6).

Ao avaliar a relação molar ao final do tratamento, o índice IPT atribui à relação molar de Classe II uma constante de elevado valor numérico, caracterizando uma condição oclusal indesejável. Contudo, o protocolo de tratamento com extrações de dois pré-molares superiores, aplicado aos pacientes do grupo 2, prevê, como meta final do tratamento uma relação de Classe II entre os molares ${ }^{47,64,113,114,124,148,181,214}$. Sendo assim, a relação dos molares em Classe II e dos caninos em Classe I, ao final do tratamento, foi considerada normal e desejável para os pacientes pertencentes ao grupo 2, não constituindo razão cabível de agravamento no momento de aplicação do índice IPT.

Esta possibilidade de variação da relação molar ao término do tratamento é prevista no cálculo do índice $\mathrm{PAR}^{48,172}$. Para tanto, este índice avalia a quantidade de discrepância ântero-posterior dos segmentos posteriores dos arcos baseando-se apenas no grau de desvio da relação 
cúspide/embrasura, não importando se a oclusão entre os arcos é de Classe I, II ou III. Uma vez que um dos objetivos principais do tratamento ortodôntico consiste em se obter uma relação de Classe I dos caninos, independente da relação ântero-posterior estabelecida na região posterior dos $\operatorname{arcos}^{47,64,113,114,124,181,214}$, os maiores pesos previstos neste índice são aplicados justamente às discrepâncias ântero-posteriores presentes na região anterior dos arcos (overjet) ${ }^{65,172}$.

Embora os índices IPT e PAR proporcionem uma avaliação fidedigna dos resultados do tratamento ortodôntico, eles não especificam quais das características oclusais mais contribuíram para as mudanças observadas, haja vista que o índice obtido para cada modelo é o resultado de um somatório de escores dados às diferentes relações oclusais que o compõem, tais como trespasse horizontal, trespasse vertical, relação ânteroposterior, mordida cruzada, apinhamento e linha média ${ }^{94,172}$. Além disso, os escores dados a cada uma das relações oclusais recebem pesos diferentes, tornando ainda mais difícil proporcionalizar a participação real de cada um dos componentes do índice no somatório final ${ }^{94,172}$. Uma vez que os pesos aplicados aos componentes do índice PAR podem ser mais facilmente removidos do que aqueles incorporados ao índice IPT, o índice PAR, obtido ao final do tratamento (PARF), foi submetido a um desmembramento em seus diferentes componentes, de modo a avaliar a participação individual das diversas relações oclusais nos resultados obtidos ${ }^{105}$.

Sendo assim, os diversos componentes do índice PAR foram submetidos a uma análise de regressão múltipla (tabela 14), avaliando a 
influência de cada uma das características oclusais sobre os resultados do tratamento. Para complementar esta investigação, o teste de Mann-Whitney foi aplicado aos componentes do índice PAR identificando as características oclusais que mais diferenciaram os grupos ao final do tratamento (tabela 15).

\subsection{Precisão da metodologia}

Assim como vários autores já formularam conceitos sobre força ótima sem que houvesse um aparelho capaz de desenvolvê-la plenamente, muitos autores já versaram a respeito das características ideais de um índice oclusal apesar de não haver um só índice que as reúna por completo. Conforme mencionado no tópico anterior, os dois índices oclusais utilizados neste estudo foram selecionados por se adequarem melhor à proposição do trabalho.

Todas as medições necessárias ao cálculo dos índices IPT e PAR foram realizadas nos modelos de gesso pré e pós-tratamento com o auxílio de um paquímetro capaz de imprimir às medidas uma precisão de até $0,1 \mathrm{~mm}$. Em seguida, estas medidas foram transformadas em escores de acordo com as convenções e normas estabelecidas nas publicações originais de cada índice ${ }^{94,172}$.

Para cada par de modelos mensurados obteve-se um total de dez escores que devidamente somados geraram o valor final dos índices IPT e PAR. Uma vez que haviam 112 pacientes avaliados ao início e final de 
tratamento, perfazendo 224 pares de modelos, um total de 2240 escores foi compilado durante este estudo.

Considerando, resumidamente, que as medições realizadas nos modelos foram traduzidas em escores e estes somados para a obtenção dos índices, o valor final de cada índice representou com fidelidade todas as medições realizadas nos modelos, tornando-se um parâmetro consistente para a análise do erro da metodologia.

Segundo HOUSTON ${ }^{107}$, para que a precisão da metodologia seja analisada adequadamente um mínimo de 25 casos deve ser reavaliado. Sendo assim, o cálculo do erro do método foi realizado tomando-se novas medidas e calculando-se um novo índice para 30 pacientes selecionados aleatoriamente de ambos os grupos, contabilizando sessenta pares de modelos iniciais e finais,.

Têm-se ressaltado a necessidade de minimizar e controlar os erros operacionais que invariavelmente surgem quando a metodologia envolve medições em telerradiografias ${ }^{20,21,107}$. Embora determinados fatores como a imprecisão na marcação de certos pontos possa agregar às medições radiográficas um maior nível de dificuldade e subjetividade, algum grau de julgamento também pode ocorrer por parte do examinador durante a medição dos modelos e aplicação dos índices oclusais ${ }^{198}$, ressaltando, assim, a importância da análise dos erros metodológicos nestas circunstâncias. 
Segundo HOUSTON ${ }^{107}$, não basta que a metodologia utilizada seja válida para o propósito a que foi requisitada, é necessário que ela seja suficientemente precisa para permitir sua reprodução. Quando esta precisão encontra-se por algum motivo comprometida, surgem os erros que podem ser de natureza sistemática ou casual. Estes erros, quando significativos, afetam a confiabilidade dos resultados, exagerando ou obscurecendo as verdadeiras diferenças entre as variáveis estudadas

O erro sistemático ocorre quando uma determinada medida é continuamente sub ou superestimada. Se as medições são realizadas por um único examinador este tipo de erro em geral resulta de uma mudança na técnica de mensuração ou de uma tendenciosidade subconsciente do examinador em direcionar os resultados de acordo com as próprias expectativas $^{107}$. Por outro lado, HOUSTON ${ }^{107}$ considera que a principal fonte de erros casuais $^{60}$ é representada pela dificuldade e pela imprecisão em identificar ou definir certos pontos. Deve-se ressaltar que estes fatores também podem afetar significativamente a possibilidade de ocorrência dos erros sistemáticos, visto que o examinador pode alterar inadvertidamente a sua técnica de mensuração devido à imprecisão ou falta de padronização da metodologia aplicada.

A ausência de significância dos erros sistemáticos e o reduzido valor dos erros casuais detectados neste estudo decorrem tanto da padronização quanto da precisão das medições, imprimindo uma baixa variabilidade aos valores das medidas utilizadas (tabela 3). Este grau de precisão e padronização talvez possa em grande parte ser explicado pela 
simplicidade e objetividade com que os índices IPT e PAR são aplicados aos modelos de estudo, tornando os resultados bastante confiáveis e facilmente reproduzíveis. Além disso, uma importante contribuição para a redução dos erros metodológicos foi a calibração do examinador anteriormente à realização das medidas.

\subsection{Resultados}

\subsubsection{Compatibilidade dos Grupos}

Os grupos comparados foram compatíveis quanto ao tipo de Classe II, gênero, severidade inicial da má oclusão e quantidade de apinhamento inferior; porém, não o foram quanto à idade inicial (tabelas 4, 5 e 6). As implicações de cada uma destas variáveis sobre a comparação entre os grupos serão discutidas a seguir.

\section{Proporção dos tipos de Classe II}

Embora a amostra apresente más oclusões de Classe II, divisão 1 e 2, as características oclusais distintas destes dois tipos de más oclusões não comprometeram a compatibilidade dos grupos quanto ao grau de severidade. Isto porque, em geral, o maior escore aplicado ao overjet, nos casos de Classe II, Divisão 1, é quantitativamente compensado pela maior severidade do overbite e apinhamento, observados na Classe II, divisão 2. Esta compensação tende a produzir índices de valores 
semelhantes, indicando a equivalência dos dois tipos de Classe II quanto ao grau de severidade ${ }^{113}$. Além disso, os grupos mostraram-se compatíveis quanto à distribuição quantitativa dos tipos de Classe II, eliminando, definitivamente, qualquer influência significativa desta variável nos resultados (tabela 4).

\section{Gênero}

Sabe-se que gêneros diferentes apresentam, para uma mesma idade cronológica, idades biológicas distintas. Portanto, considerando uma época de maturação mais precoce e um ritmo de crescimento mais acelerado como características de desenvolvimento do gênero feminino, as melhores respostas ao tratamento ortodôntico ocorrem numa idade cronológica menor no gênero feminino do que no masculino $35,36,79,97,112,141,215$. Além dos gêneros mostrarem diferenças importantes quanto à época de maturação e ritmo de crescimento, produzindo respostas distintas a um mesmo protocolo de tratamento ortodôntico $35,36,79,97,112,141,215$, alguns autores advogam que gêneros diferentes podem apresentar níveis distintos de colaboração, beneficiando ou comprometendo as metas do tratamento ${ }^{59,81,193}$. Considerando que o potencial de crescimento presente é um importante fator na correção da Classe II e que o sucesso dos diversos métodos de correção desta má oclusão dependem, em algum grau, da cooperação do paciente $e^{6,16,37,57,64,72,74,76,101,102,113,118,155,216}$, a compatibilidade estabelecida 
entre os grupos quanto ao gênero foi de grande importância para o controle da influência desta variável sobre os resultados (tabela 5).

\section{Severidade inicial da má oclusão e quantidade de apinhamento}

inferior

A compatibilidade entre os grupos quanto à severidade inicial da discrepância ântero-posterior foi determinada no momento da seleção da amostra, uma vez que todos os pacientes deveriam apresentar uma má oclusão de Classe II completa. Portanto, o grau de dificuldade de correção da relação ântero-posterior não diferiu entre os grupos. Além disso, os índices IPT e PAR, obtidos a partir dos modelos pré-tratamento mostraram que ao se adicionar outras características oclusais como overbite, overjet, apinhamento e linha média, os grupos continuaram a ser compatíveis (tabela 6). Este fato pode ser explicado, em parte, pela influência que a discrepância ântero-posterior, pré-estabelecida, exerce sobre as demais características oclusais $^{25,38}$. Por outro lado, a ausência de extrações no arco inferior e a simetria bilateral da Classe II favoreceram a obtenção de graus semelhantes de apinhamento inferior e desvio da linha média na amostra, contribuindo ainda mais para que a média dos índices IPT e PAR ao início do tratamento, fosse semelhante entre os grupos. 


\section{$\underline{\text { Idade inicial }}$}

A incompatibilidade dos grupos quanto à idade inicial (tabela 6) poderia influenciar os resultados deste estudo no sentido de favorecer a obtenção de melhores resultados oclusais no grupo sem extrações, visto que este grupo apresentava a menor média de idade ao início do tratamento. Com o intuito de avaliar o grau de influência da idade inicial sobre os resultados do tratamento, realizou-se um segundo teste estatístico onde os resultados do tratamento foram comparados, considerando a compatibilidade dos grupos quanto à idade inicial e severidade inicial da má oclusão.

\subsubsection{Resultados oclusais}

Os resultados da comparação intergrupos dos índices IPT e PAR evidenciaram que ao final do tratamento o grupo 2 apresentou as melhores relações oclusais (Tabela 6). Considerando que: 1) a amostra foi criteriosamente selecionada; 2) a metodologia aplicada foi adequada e suficientemente precisa; 3) os grupos foram compatíveis quanto ao tipo de Classe II; gênero e severidade inicial da má oclusão (tabelas 4, 5 e 6) e 4) a menor idade inicial do grupo 1 (tabela 6) favoreceu a obtenção de melhores resultados oclusais neste grupo, torna-se evidente a relação de influência estabelecida entre a qualidade dos resultados ortodônticos e o protocolo de 
tratamento utilizado. Contudo, para ser melhor compreendida, esta evidência necessita ser discutida no contexto dos tratamentos ortodônticos.

Provavelmente, a maior complexidade do protocolo de tratamento da Classe II completa, sem extrações, contribui para explicar a diferença estatisticamente significante observada entre os grupos quanto à idade inicial. Se a correção da má oclusão de Classe II em pacientes mais jovens tende a ser favorecida em função da maior quantidade de crescimento presente ${ }^{49,70,101,155,205}$, era mesmo de se esperar que o protocolo de tratamento de maior complexidade estivesse relacionado ao grupo de pacientes com maior potencial de crescimento (grupo 1). A necessidade de correção da relação molar impõe ao tratamento sem extrações um maior grau de dificuldade, sobretudo em pacientes com reduzido potencial de crescimento remanescente. Por outro lado, o protocolo de duas extrações pode ser utilizado com elevado percentual de eficiência em pacientes com menor quantidade de crescimento ${ }^{161}$ (faixa etária mais avançada), visto que a correção da relação molar não compõe os objetivos deste tratamento $^{47,64,160,161,181,214}$.

A incompatibilidade dos grupos quanto à idade inicial poderia afetar os resultados deste estudo no sentido de favorecer a obtenção de melhores resultados oclusais no grupo sem extrações, visto que este grupo apresentava a menor média de idade ao início do tratamento e, por conseguinte, um maior potencial de crescimento, favorecendo a correção da má oclusão de Classe II ${ }^{49,70,101,155,205}$. Porém, os resultados mostraram que apesar deste favorecimento, as melhores relações oclusais ocorreram no 
grupo 2 (tabela 6), até mesmo quando a idade entre os grupos foi compatibilizada (tabela 7), evidenciando, mais uma vez, a significativa influência do protocolo de tratamento no grau de melhora obtido.

O percentual de melhora é um valor representativo da fração da má oclusão corrigida, tomando-se como referência sua condição inicial, enquanto a quantidade de melhora é um valor que apenas quantifica a correção sem considerar o seu valor representativo em relação ao problema inicial (proporção de correção). Sendo assim, o sucesso do tratamento é melhor retratado pelo percentual de melhora ${ }^{30,105}$, uma vez que o cálculo desta medida estabelece uma relação entre a quantidade de melhora e a severidade inicial da má oclusão ${ }^{13}$. O maior percentual de melhora, observado no grupo com extrações de dois pré-molares superiores (Tabela 6), demonstrou que este protocolo de tratamento propiciou os melhores resultados, reduzindo um maior percentual da má oclusão inicial do que o protocolo de tratamento sem extrações.

Esta evidência pôde ser perfeitamente visualizada a partir de uma análise descritiva dos resultados (tabelas 8 e 9), demonstrando que ao se extrair dois pré-molares superiores para correção da Classe II completa, um maior percentual de pacientes apresentou, ao término do tratamento, índices oclusais iguais a zero, ou seja, uma relação oclusal próxima ao ideal. Além disso, à medida que os resultados se distanciaram do ideal (IPT e PAR diferentes de zero), uma maior proporção de pacientes do grupo com extrações manteve seus resultados próximos ao ideal, evidenciando que este protocolo de tratamento produziu resultados oclusais melhores e de 
menor variabilidade. Isto porque as extrações dentárias no arco superior, por si, já asseguram a correção de metade da discrepância ântero-posterior, independente do grau de cooperação do paciente. O protocolo de tratamento sem extrações proporcionou uma qualidade de finalização satisfatória numa proporção considerável de pacientes do grupo 1, contudo, os valores mais díspares observados nos índices finais foram relacionados a este protocolo. Além disso, segundo as interpretações de RICHMOND et al. ${ }^{172,174}$, quando o valor obtido para o índice PAR ao final do tratamento é menor ou igual a 5, considera-se a oclusão quase perfeita. Uma vez que neste limiar de correção situa-se $86,9 \%$ dos pacientes do grupo com extrações e 53,4\% dos pacientes tratados sem extrações, pode-se afirmar que uma maior proporção de sucesso do tratamento foi obtido quando as más oclusões de Classe ॥ completa foram tratadas com extrações de dois pré-molares superiores. Por outro lado, valores do índice PAR maiores que 5 e menores que 10 retratam uma qualidade de finalização apenas razoável ${ }^{172,174}$. Este intervalo agrega $27,9 \%$ dos pacientes tratados sem extrações e $11,6 \%$ dos pacientes tratados com extrações. Pode-se, então, concluir que a proporção de pacientes do grupo tratado sem extrações aumenta, consideravelmente, em relação àqueles tratados com extrações à medida que os resultados do tratamento se afastam do ideal, atingindo uma proporção próxima de 3:1 quando o valor final do índice PAR foi considerado entre 5 e 10. Portanto, deve-se ressaltar que embora o tratamento

Os resultados menos satisfatórios e de maior variabilidade, provenientes do tratamento da Classe II sem extrações (tabelas 8 e 9) estão, 
provavelmente, relacionados à maior necessidade de cooperação do paciente, uma vez que esta forma de tratamento da Classe II pressupõe a correção da relação molar ${ }^{64,76,124,207,214}$. Considerando que os dispositivos ortodônticos destinados a este fim são em sua grande maioria removíveis e, portanto, dependentes da colaboração do paciente, a qualidade de finalização do tratamento torna-se pouco previsível 6 6,16,37,57,76,113,216.

Depreende-se, portanto, que o sucesso do tratamento da Classe II sem extrações encontra-se extremamente vinculado à cooperação do paciente. Deve-se ainda ressaltar que quanto mais severa for a má oclusão inicial maior será a necessidade de colaboração do paciente para se obter um resultado final satisfatório ${ }^{111,216}$. Uma vez que a severidade inicial da má oclusão é uma característica inerente à mesma, não podendo portanto, ser controlada, tem-se direcionado os esforços para eliminar ou pelo menos minimizar a necessidade de colaboração do paciente.

Tomando-se o grau de severidade da má oclusão como um indicador da necessidade de cooperação do paciente é possível afirmar que a correção da má oclusão de Classe II completa requer um elevado grau de colaboração do paciente. Porém, conforme demonstrado teoricamente pelos estudos de ANDREWS ${ }^{8}$ e clinicamente pelos trabalhos de JANSON $^{113,114}$, o protocolo de tratamento da má oclusão de Classe II com extrações de prémolares superiores requer um menor nível de colaboração do paciente para a obtenção de resultados oclusais satisfatórios, justificando, assim, a maior proporção de sucesso deste protocolo no tratamento das más oclusões de Classe II mais severas (tabelas 8 e 9). 
À luz dos estudos de ANDREWS ${ }^{8}$, serão discutidos a seguir dois dos principais protocolos de tratamento da má oclusão de Classe II completa bilateral (tratamento sem extrações e com extrações de dois prémolares superiores), no que se refere à necessidade de colaboração do paciente.

Segundo ANDREWS ${ }^{8}$, para a correção de cada milímetro de protrusão ou apinhamento são necessárias 2 unidades de espaço (UE). As unidades de espaço requeridas (UER) podem ser obtidas de diversas formas, sendo que as extrações, desgastes e expansões independem da cooperação do paciente e são denominadas Unidades de Espaço Disponíveis (UED). As distalizações e manutenções das unidades de ancoragem são, por excelência, dependentes da colaboração do paciente e, portanto, consideradas como Unidades de Espaço Potenciais (UEP). Sendo assim, numa Classe II completa, tratada sem extrações, os $7 \mathrm{~mm}$ de discrepância ântero-posterior requerem 14 unidades de espaço de cada lado para serem corrigidos, somando um total de 28 UE que precisam ser obtidas às custas da cooperação do paciente (Unidades de Espaço Potenciais), visto que o plano de tratamento não previu extrações (Figura 1).

Considerando que 28 unidades de espaço (UE) são requeridas para corrigir os $7 \mathrm{~mm}$ de discrepância ântero-posterior da má oclusão de Classe II completa, a realização de duas extrações no arco superior proverá 14 UE, independentemente da colaboração do paciente (Unidades de Espaço Disponíveis). Estas unidades de espaço obtidas das extrações são utilizadas para corrigir a discrepância ântero-posterior das unidades 
dentárias anteriores, sendo que as outras 14 UE são referentes à manutenção da relação ântero-posterior das unidades dentárias posteriores e, portanto, dependem da cooperação do paciente para serem obtidas (Unidades de Espaço Potenciais). Sendo assim, o tratamento da má oclusão de Classe II completa com extração de dois pré-molares superiores difere do protocolo de tratamento sem extrações já descrito, não apenas no tocante à realização ou não de extrações, mas sobretudo no que diz respeito à redução pela metade da necessidade de colaboração do paciente durante o tratamento.

Deve-se salientar que quando o paciente se encontra na fase ativa de crescimento, as Unidades de Espaço Potenciais podem ser mais facilmente obtidas em função das alterações esqueléticas serem somadas às movimentações dentárias, favorecendo, assim, a correção das más oclusões. Porém, se um paciente com reduzido potencial de crescimento é submetido a um protocolo de tratamento que requer um elevado número de Unidades de Espaço Potenciais para a correção da má oclusão (correção da Classe II completa, sem extrações), o nível de dificuldade do tratamento e o grau de colaboração requerido tornam-se significativamente aumentados, comprometendo, por vezes, o sucesso do tratamento. Por outro lado, a menor quantidade de Unidades de Espaço Potenciais, necessárias à correção da Classe II com duas extrações, permite que uma elevada proporção de sucesso (74\%) seja obtida mesmo quando este protocolo de tratamento é aplicado em pacientes que não apresentam qualquer crescimento durante o tratamento ${ }^{161}$. 
Um exemplo de movimentação utilizada para manter a relação ântero-posterior durante a correção da Classe II completa com extração de dois pré-molares foi ilustrado por ANDREWS ${ }^{8}$ e reproduzido na Figura 2. Num primeiro estágio do tratamento (Figura 2A), a colaboração do paciente é necessária para que as unidades dentárias anteriores e posteriores sejam distalizadas 3,5 mm obtendo-se as 14 Unidades de Espaço Potenciais, necessárias ao tratamento da Classe II com extrações, sem que os $7 \mathrm{~mm}$ de espaço provenientes da extração (UED) sejam alterados. Portanto, num segundo estágio do tratamento (Figura 2B), a má oclusão de Classe II, completa foi revertida numa má oclusão de $1 \frac{1}{2}$ Classe II, com $7 \mathrm{~mm}$ de espaço de cada lado ou 14 Unidades de Espaço Disponíveis para serem fechados. Num terceiro estágio do tratamento (Figura 4C), os $7 \mathrm{~mm}$ de espaço da extração (14 UED), são suficientes para corrigir a má oclusão de 1/2 Classe II sem a necessidade de colaboração do paciente, de modo que as unidades dentárias anteriores são distalizadas $3,5 \mathrm{~mm}$, enquanto as unidades dentárias posteriores são mesializadas $3,5 \mathrm{~mm}$, obtendo-se uma relação de Classe I dos caninos e de Classe II dos molares. De acordo com este esquema de movimentação, apenas o primeiro estágio do tratamento, correspondente aos 3,5mm de distalização (14 UEP), requer a colaboração do paciente. Sabe-se, porém, que numa má oclusão de Classe II completa, tratada sem extrações, o grau colaboração do paciente deve ser tal que promova uma distalização de $7 \mathrm{~mm}$ das unidades dentárias anteriores e posteriores (28 UEP), Figura 1. Fica, portanto, evidente a razão pela qual o 
tratamento com duas extrações requer apenas da metade da colaboração necessária a um tratamento sem extrações.

Em síntese, o tratamento da Classe II completa com extração de dois pré-molares superiores requer do paciente, aproximadamente, a metade do grau de colaboração previsto nos protocolos de tratamento sem extrações. Esta constatação contribui para explicar a maior eficiência deste protocolo de tratamento, produzindo resultados melhores e mais previsíveis $^{47,113,114}$.

A recente utilização dos implantes ortodônticos como ancoragem absoluta nos tratamento da Classe II completa com extrações de dois pré-molares superiores tem proporcionado resultados mais previsíveis, visto que o grau de colaboração do paciente não interfere significativamente na obtenção dos objetivos do tratamento ${ }^{41,52,195,204,212}$. Contudo, deve-se considerar que a utilização dos implantes ortodônticos como ancoragem envolve os riscos e o ônus de uma intervenção cirúrgica, além de estar sujeita aos insucessos relacionados à estabilidade dos implantes. Sendo assim, este tipo de procedimento enquadra-se melhor nos casos em que o paciente além de apresentar uma má oclusão de Classe II severa, também possui uma reduzida quantidade de crescimento remanescente.

Sabe-se que independente da mecânica utilizada, a quantidade de distalização do primeiro molar superior dificilmente é suficiente para corrigir toda a discrepância ântero-posterior de uma má oclusão de Classe II completa $^{11}$. Sendo assim, alguma mesialização do molar inferior deve ocorrer a fim de possibilitar a correção da relação molar. Nos casos em que 
o paciente apresenta-se na fase ativa de crescimento, a maior quantidade de crescimento mandibular favorecerá significativamente uma maior mesialização do molar inferior em relação ao molar superior, sobretudo se o crescimento maxilomandibular for redirecionado por meio de forças extrabucais e/ou aparelhos funcionais ${ }^{11,50,64,72,74,76,102,118,155,179}$. Porém, quando o tratamento da Classe II é realizado numa fase tardia do desenvolvimento, onde o potencial de crescimento é mínimo ou inexistente, a mesialização do molar inferior, necessária à correção da relação molar, dependerá exclusivamente da movimentação dentária, em geral, obtida com o uso de elásticos intermaxilares, requerendo um grau máximo de colaboração do paciente ${ }^{70,101,205}$. Uma vez que o tratamento da má oclusão de Classe II com extração de dois pré-molares superiores não intenciona a correção da discrepância ântero-posterior dos molares ${ }^{47,64,113,114,124,148,181,214}$, os objetivos do tratamento podem ser mais facilmente alcançados com um menor grau de colaboração ${ }^{47,113,114}$, constituindo, assim o protocolo de tratamento mais indicado para pacientes adultos com má oclusão de Classe ${ }^{47,64,155,161,181,214}$. Quando um significativo potencial de crescimento ainda está presente, a necessidade de colaboração do paciente para se obter uma relação de Classe I dos caninos, sem alterar a relação de Classe II dos molares, torna-se ainda mais reduzida. Isto porque o deslocamento para mesial do molar inferior, decorrente da maior quantidade de crescimento mandibular e restrição do crescimento maxilar, tende a compensar a perda de ancoragem do molar superior, mantendo a relação molar de Classe II enquanto os dentes anteriores superiores são retraídos. Este diferencial de 
metas do tratamento em relação à correção da relação molar contribui consideravelmente para explicar a aparente contradição do grupo tratado com extrações apresentar um menor potencial de crescimento e, ao mesmo tempo, melhores resultados de correção da Classe II.
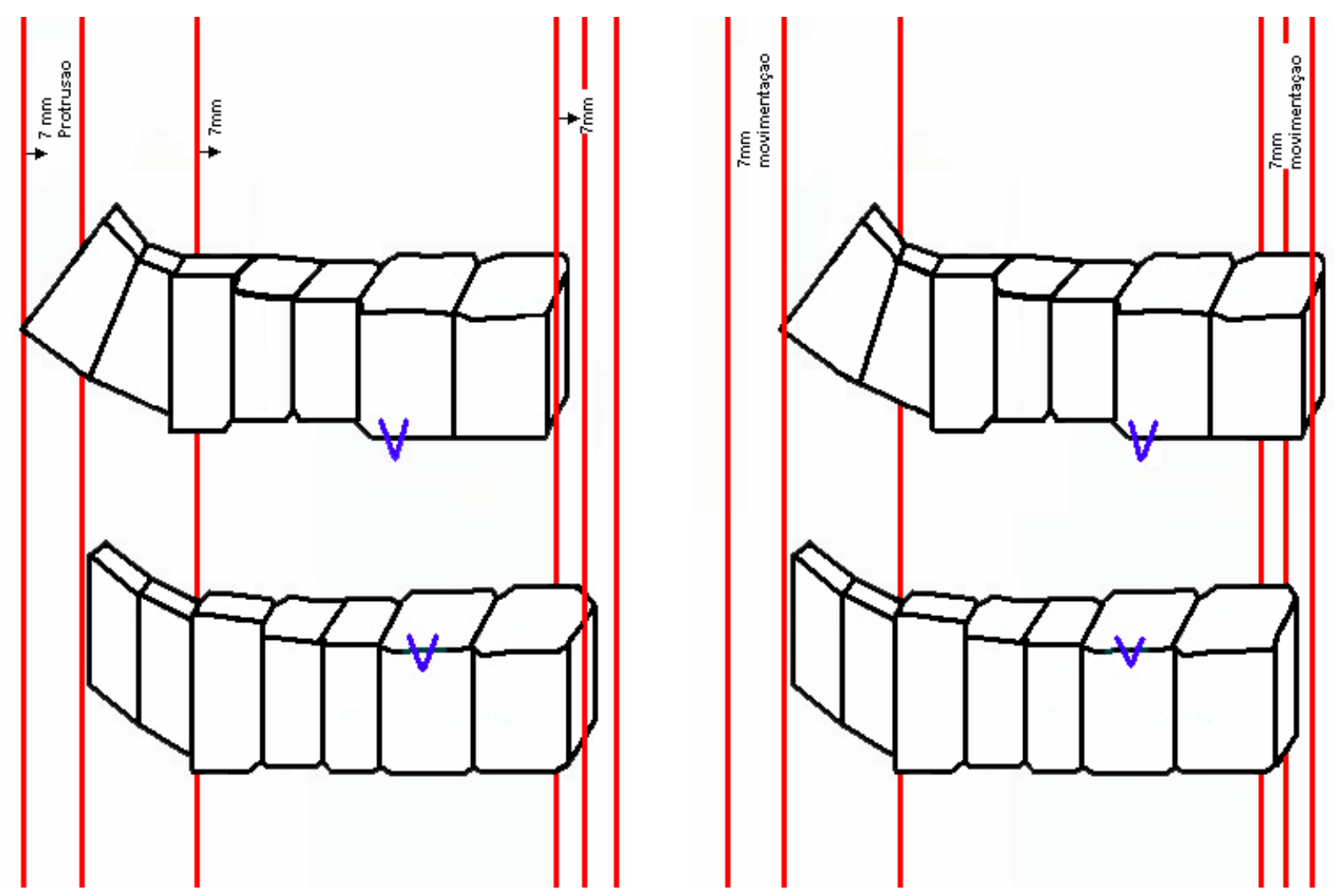

FIGURA 1 - Correção da má oclusão de Classe II completa, sem extrações. 


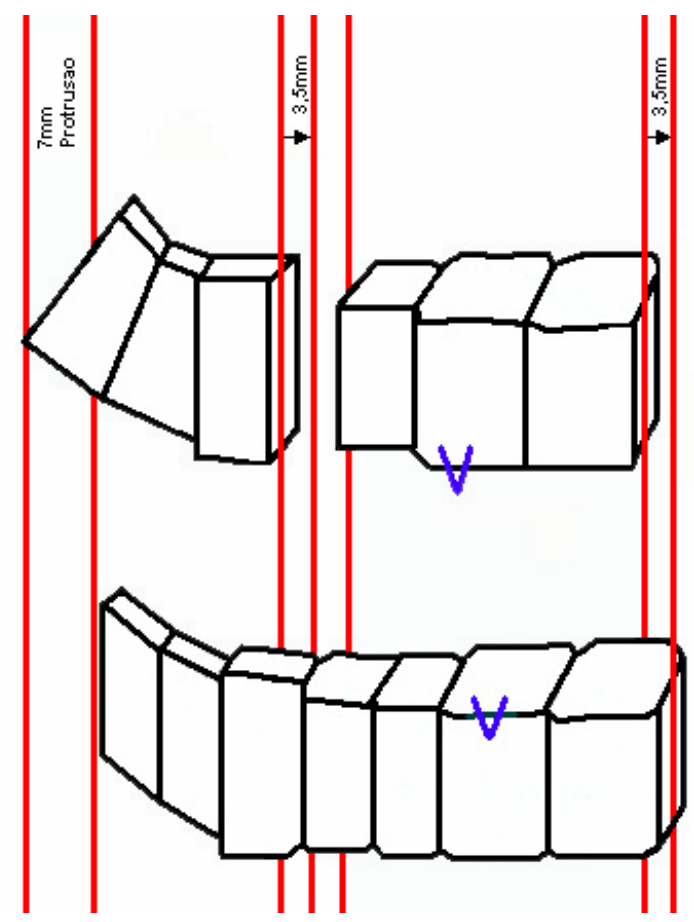

FIGURA 2A - Estágio I do tratamento.

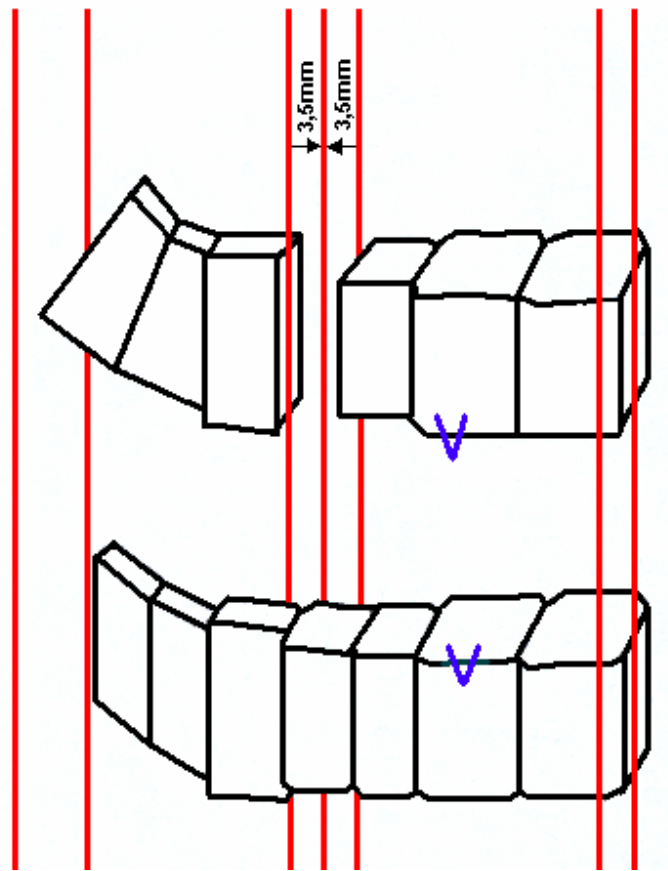

FIGURA 2B - Estágio II do tratamento.

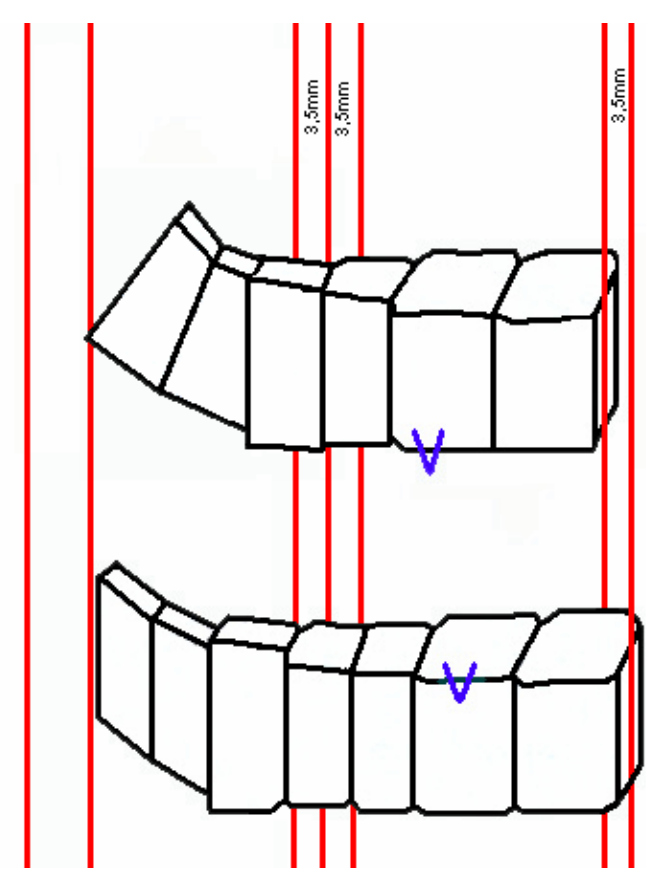

FIGURA 2C - Estágio III do tratamento.

FIGURA 2 - Correção da má oclusão de Classe II completa, com extrações de dois prémolares superiores. 


\subsubsection{A influência do replanejamento (extrações tardias)}

Por ser de caráter retrospectivo, este estudo apresenta uma limitação que necessita ser considerada a fim de que a real diferença entre os dois protocolos de tratamento seja dimensionada, tanto em relação aos resultados oclusais, quanto ao tempo de tratamento. A maior possibilidade de planificação, inerente aos estudos prospectivos, permitiria que os resultados oclusais dos pacientes replanejados fossem devidamente registrados antes de iniciar o tratamento com extrações. Estes supostos registros seriam, então, representativos dos resultados finais alcançados com o protocolo de tratamento sem extrações em pacientes pouco colaboradores. Apenas desta forma o grupo tratado sem extrações apresentaria resultados reais que seriam provenientes de todos os níveis de colaboração, tal como ocorre no grupo tratado com extrações. A possibilidade do replanejamento faz com que o protocolo de tratamento sem extrações seja auto-seletivo, permanecendo para serem tratados apenas os pacientes de melhor colaboração. Esta seleção beneficia os resultados do grupo tratado sem extrações, mascarando a verdadeira diferença de efetividade existente entre estes dois protocolos de tratamento. Especula-se, portanto, que a verdadeira discrepância no grau de eficiência clínica destes dois protocolos de tratamento seja ainda maior do que foi observado neste estudo. Porém, a investigação desta hipótese só é possível a partir de um estudo conduzido dentro dos parâmetros explicitados.

Constatou-se que o grupo tratado com extrações superiores apresentou um elevado percentual de pacientes replanejados $(31,8 \%)$ 
devido à tentativa mal sucedida de se corrigir a má oclusão de Classe II completa, sem extrações ${ }^{140}$. A hipótese de que o subgrupo de pacientes replanejados obteve alguma melhora na severidade de suas más oclusões durante a tentativa de corrigir a Classe II sem extrações foi investigada. Ao iniciar o tratamento com extrações, apresentando uma má oclusão menos severa, este subgrupo de pacientes replanejados tenderia a apresentar um maior percentual de melhora ao final do tratamento, beneficiando os resultados do grupo tratado com extrações. Estatisticamente esta hipótese não se confirmou (tabela 10), visto que os resultados finais do tratamento deste subgrupo não foram significativamente melhores quando comparados aos do subgrupo não replanejado, sugerindo que pouca ou nenhuma melhora ocorreu neste período de tratamento sem extrações. Portanto podese concluir que a falta de colaboração do paciente, em muitos casos $(31,8 \%)$, impede a progressão do tratamento sem extrações e exige do profissional a escolha de uma nova conduta que seja mais eficiente e, portanto, menos dependente da cooperação do paciente. Nestes casos a escolha, em geral, recai sobre o protocolo de tratamento com extrações de dois pré-molares superiores, visto que o planejamento sem extrações, realizado anteriormente, pressupõe a ausência de uma significativa quantidade de apinhamento no arco inferior.

Embora o replanejamento não tenha influenciado nos resultados do tratamento, o tempo de tratamento foi significantemente aumentado por este fator. Contudo, uma discussão mais detalhada sobre a 
influência do replanejamento no tempo de tratamento será realizada no tópico específico a este assunto (6.4.5 Tempo de tratamento).

\subsubsection{A influência do tratamento em duas fases}

Alguns trabalhos têm afirmado que melhores resultados terapêuticos podem ser alcançados quando o tratamento da Classe II é realizado em duas fases ${ }^{19,90,176,222}$, muito embora esta afirmação seja motivo de constante controvérsia ${ }^{67,137,162,199,200}$. Sabendo-se que 21 dos 43 pacientes tratados sem extrações (grupo 1) tiveram seus tratamentos ortodônticos precedidos por uma fase ortopédica, considerou-se a hipótese de que estes pacientes, tratados em duas fases (subgrupo 1B), poderiam ter alcançado uma qualidade de finalização do tratamento semelhante aos pacientes tratados com extrações (grupo 2). A partir desta hipótese poderse-ia conjecturar que o resultado menos satisfatório do grupo tratado sem extrações foi devido ao percentual de pacientes tratados em uma única fase (subgrupo 1A). Porém, ao comparar os pacientes do grupo 1, tratados sem extrações e em duas fases (subgrupo 1B) com aqueles tratados com extrações (grupo 2), observou-se que a qualidade dos resultados obtidos com o tratamento sem extrações permaneceu significantemente inferior àquela verificada nos tratamentos com extrações, demonstrando que o número de fases do tratamento não se relacionou à qualidade de finalização do mesmo (tabela 12). Os resultados desta comparação parecem coerentes com a afirmação de que a correção da relação molar foi o fator que mais dificultou a obtenção do sucesso do tratamento sem extrações, levando a 
crer que independente do número de fases do tratamento, o grau de dificuldade imposto pela necessidade de correção da relação molar permanece inalterado sempre que a correção da Classe II é planejada sem extrações.

Com relação ao tempo de tratamento, vários autores têm demonstrado que o tratamento da má oclusão de Classe II em duas fases, por si, prolonga o tratamento $24,137,150,162,201,208$. Considerando que 21 dos 43 pacientes tratados sem extrações (grupo 1) apresentaram seus tratamentos realizados em duas fases (subgrupo 1B), tornou-se necessário investigar a influência do número de fases do tratamento sobre a duração do tratamento do grupo 1. Os resultados desta averiguação estão discutidos no item subseqüente.

\subsubsection{Tempo de tratamento}

O tempo de tratamento total foi semelhante entre os grupos (tabela 6). Considerando que vários autores apontam as extrações dentárias e a correção da relação molar como variáveis potencialmente capazes de influenciar o tempo de tratamento ${ }^{54,77,105,150,175,201,207,208}$, pensou-se, a priori, que a semelhança do tempo de tratamento entre os grupos seria decorrente da igual influência destas variáveis, visto que num dos grupos a relação molar foi corrigida sem fazer extrações, enquanto no outro foram realizadas extrações superiores, mantendo-se a relação molar de Classe II. Contudo, durante a obtenção das informações constantes dos prontuários, observou- 
se que uma quantidade significativa $(31,8 \%)$ dos pacientes do grupo tratado com extrações superiores, foi submetida a um replanejamento do tratamento em razão do insucesso do planejamento inicial em tratar a má oclusão de Classe II completa, sem extrações. A hipótese ${ }^{191}$ de que a tentativa frustrada de correção da Classe II sem extrações aumentou o tempo de tratamento deste subgrupo de pacientes replanejados foi confirmada pela comparação do tempo de tratamento dos subgrupos com extrações, replanejados e não replanejados (tabela 10). Os resultados mostraram que o tempo de tratamento com extrações superiores foi maior no subgrupo replanejado. Quando comparado ao grupo tratado sem extrações, o subgrupo não replanejado apresentou um menor tempo de tratamento, enquanto no subgrupo replanejado observou-se um tempo de tratamento semelhante. Pode-se, então afirmar que quando o planejamento inicial do tratamento foi cumprido, o tempo de tratamento foi maior no grupo tratado sem extrações. Esta afirmação contesta a suposição inicial de que as extrações dentárias exercem uma influência preponderante sobre o tempo de tratamento.

Vários trabalhos têm relacionado a realização de extrações com o aumento do tempo de tratamento ${ }^{54,77,105,150,175,201,207,208}$. Realmente, seria de se esperar que o tratamento de uma má oclusão de Classe I sem extrações tivesse uma duração mais curta do que com extrações de quatro pré-molares, uma vez que a retração anterior superior e inferior, nos casos com extrações, representa o acréscimo de uma fase ao tratamento da má oclusão de Classe I. 
Seguindo este mesmo raciocínio, seria previsível que o tratamento da Classe I sem extrações apresentasse um menor tempo de tratamento do que o tratamento da Classe II sem extrações. Isto porque o tratamento da má oclusão de Classe II apresenta em relação ao tratamento da Classe I o acréscimo de uma meta ao tratamento que é a correção da relação ântero-posterior.

Pode-se, então, concluir que ao analisar os fatores que influenciam o tempo de tratamento, utilizando vários tipos de más oclusões $^{24,105,175,201,208}$, provavelmente obter-se-á resultados que não poderão ser extrapolados para uma classe isolada de má oclusão, uma vez que o protocolo de tratamento indicado para cada má oclusão poderá instituir variáveis que the são peculiares, distorcendo desta forma os resultados.

Neste estudo pôde-se observar que o tempo de tratamento da Classe II completa sem extrações foi significantemente maior do que aquele observado com extrações de dois pré-molares superiores (tabela 10). Considerando que se trata de uma amostra homogênea quanto ao tipo e severidade inicial da má oclusão, pode-se afirmar que a realização de extrações, por si, não aumentou significantemente o tempo de tratamento.

Se a realização de extrações não influenciou significantemente o tempo de tratamento, conclui-se que o maior tempo de tratamento evidenciado no grupo de Classe II sem extrações decorreu, sobretudo, da impreterível necessidade de se corrigir a relação molar ${ }^{175,201,207}$. Uma vez que o protocolo de tratamento com extrações de dois pré-molares superiores 


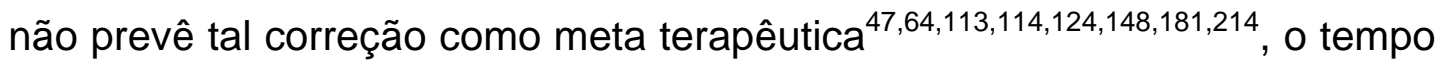
de tratamento mostrou-se significativamente menor.

Segundo ANDREWS ${ }^{8}$, a quantidade de movimentação dentária necessária à correção de um determinado tipo de má oclusão é um fator importante na predição do tempo de tratamento. Contudo, más oclusões semelhantes podem apresentar tempos de tratamento significativamente distintos quando são aplicados protocolos de tratamento que exigem do paciente diferentes graus de colaboração.

Considerando que o grau de cooperação do paciente está relacionado ao sucesso $0^{6,37,57,76,113,132,216}$ e à duração do tratamento $24,54,77,140,175,191$, é compreensível que protocolos de tratamentos essencialmente dependentes da cooperação do paciente com o uso de elásticos intermaxilares, aparelhos extrabucais e aparelhos funcionais, tendam a apresentar uma menor proporção de sucesso e tempo de tratamento aumentado. A maior necessidade de colaboração com estes aparelhos está, em geral, relacionada aos protocolos de tratamento que envolvem a correção da relação molar, explicando assim a correlação entre a correção da relação molar, uso de AEB e tempo de tratamento, evidenciada por vários autores $24,54,175,201,207$.

Alguns trabalhos não têm mostrado relação entre a idade do paciente e o tempo de tratamento ${ }^{24,77,175}$, enquanto outros, sugerem que o início do tratamento numa idade muito precoce ou na idade adulta tendem a aumentar o tempo de tratamento ${ }^{54,191,208}$. Considerando que os pacientes de ambos os grupos apresentam-se no período pubescente, propício ao 
tratamento da Classe II, a menor idade inicial do grupo sem extrações é um fator que pode favorecer a correção da Classe II num menor tempo de tratamento, pois a maior quantidade de crescimento, atuando em sinergia com a mecânica ortodôntica aplicada tende a acelerar a correção da discrepância ântero-posterior presente entre os arcos. Não obstante este favorecimento, o grupo com idade inicial mais avançada apresentou um menor tempo de tratamento. Esta aparente incoerência dos resultados pode ser explicada pela diferença entre os dois protocolos de tratamento quanto à necessidade de colaboração do paciente. Apesar dos grupos diferirem quanto à quantidade de crescimento remanescente, a menor necessidade de colaboração no grupo com extrações ${ }^{8,113,124,140}$ fez com que a eficiência deste protocolo de tratamento fosse significativamente maior, favorecendo um menor tempo de tratamento. A confiabilidade desta conclusão fica ainda mais reforçada pelo fato do tempo de tratamento dos pacientes tratados com extrações permanecer menor mesmo quando a idade inicial dos grupos foi compatibilizada (tabela 11).

Os trabalhos realizados com o propósito de identificar as diversas variáveis que podem influenciar no tempo de tratamento sugerem que o número de faltas às consultas e quebras dos aparelhos pode alterar o tempo de tratamento $24,54,77,150,175,191$. Considerando que estas variáveis apresentam uma mesma probabilidade de ocorrência entre os grupos por serem representativas não apenas do grau de colaboração, mas também das características psicossociais e comportamentais do paciente ${ }^{17,24,54,77,175}$, admitiu-se a compatibilidade dos grupos em relação a estes fatores. Além 
disso, se houvesse alguma tendência dos grupos se diferirem em relação ao grau de colaboração do paciente, seria de se esperar que o menor nível de colaboração ocorresse no grupo com extrações, haja vista que este grupo apresenta um elevado percentual de pacientes que foram replanejados (31,8\% - subgrupo 2B) em função de serem, reconhecidamente, não colaboradores. Deve-se ainda considerar que os pacientes replanejados apresentavam um tempo extra de tratamento, proveniente do período de tentativa de correção da Classe II sem extrações. No entanto, a despeito de todas estas desvantagens adicionadas ao grupo 2 (pacientes tratados com extrações) pelo subgrupo de pacientes replanejados (subgrupo 2B), o grupo com extrações, como um todo, apresentou melhores resultados ortodônticos num menor tempo de tratamento. Outras variáveis que poderiam influenciar no tempo de tratamento como a presença de dentes impactados, necessidade de cirurgia ortognática e agenesias dentárias foram eliminadas no momento da seleção da amostra.

Poderia se pensar que o tempo de tratamento observado no grupo sem extrações foi influenciado pelo fato de alguns pacientes serem submetidos à terapia corretiva após um período de uso do AEB e/ou aparelhos funcionais. Contudo, este pensamento parece equivocado, pois se por um lado os pacientes tratados sem extração tiveram a relação molar parcialmente corrigida para depois passar à fase de alinhamento e nivelamento dos dentes, por outro, os pacientes tratados com extração tiveram seus dentes alinhados e nivelados para depois passar à fase de correção da relação dos caninos (retração anterior). Portanto, conclui-se 
que a diferença no tempo de tratamento não ocorreu em função do número de fases, mas sim pelo fato da correção da relação molar depender mais da colaboração do paciente do que o posicionamento do canino em uma relação de Classe $1^{17,24,54,77,175}$. Além disso, se não fosse o maior grau de dificuldade, o maior tempo despendido no tratamento da Classe II sem extrações deveria resultar numa melhor qualidade de finalização ${ }^{71,142}$.

Para investigar com maior rigor científico a hipótese de que a maior duração do tratamento do grupo sem extrações ocorreu em função de alguns pacientes deste grupo terem sido tratados em duas fases, (subgrupo 1B), comparou-se o tempo de tratamento dos pacientes do grupo 1, tratados sem extrações e em uma fase (subgrupo 1A), com aqueles do grupo 2, submetidos ao tratamento com extrações e não replanejados (subgrupo 2A). Os resultados demonstraram que o tratamento sem extrações, realizado em uma única fase, foi significantemente mais prolongado, evidenciando que o maior tempo de tratamento do grupo sem extrações não se relaciona ao número de fases do tratamento (tabela 13). Nesta comparação, a exclusão dos pacientes replanejados torna-se necessária em função da já demonstrada influência do replanejamento sobre o tempo de tratamento (tabela 10).

O critério utilizado para classificar o tratamento sem extrações quanto ao número de fases baseou-se no menor tempo relatado na literatura para a fase ortopédica de correção da Classe $\|^{19,222}$. Portanto, pacientes que por um período igual ou superior a 6 meses utilizaram apenas aparelhos ortopédicos como meio de correção da má oclusão de Classe II passaram a 
constituir o subgrupo tratado em duas fases (subgrupo 1B). Este parâmetro de classificação permitiu que no subgrupo de pacientes tratados sem extrações e em uma só fase (subgrupo 1A), permanecessem apenas os pacientes que não foram submetidos a tratamento ortopédico ou, então, que receberam tratamento ortopédico concomitantemente ao tratamento ortodôntico, reduzindo ao máximo o tempo de tratamento deste subgrupo. Ainda assim, o tempo de tratamento do subgrupo tratado sem extrações e em uma fase (subgrupo $1 \mathrm{~A}$ ), foi significantemente maior em relação ao subgrupo 2A, tratado com extrações e não replanejado (tabela 13).

Considerando apenas o tratamento da Classe II sem extrações, vários autores já demonstraram que o tempo de tratamento é menor para a correção em uma fase do que em duas $24,137,150,162,201,208$. Estes resultados parecem lógicos, visto que no tratamento em uma fase os dentes são melhor posicionados em cada arco, ao mesmo tempo em que se reduz a discrepância interarcos. Porém, a maior duração do tratamento em duas fases quando comparado ao tratamento com extrações de pré-molares superiores, deve-se à dificuldade de se corrigir a relação molar e não ao simples fato de se dividir o tratamento em fases. Portanto, especula-se que numa escala ordinal do tempo de tratamento, os protocolos de tratamento vinculados à correção da relação molar tendem a apresentar um maior tempo de tratamento do que aqueles que mantêm esta relação ânteroposterior. 


\subsection{A eficiência do tratamento ortodôntico}

Em geral, o surgimento de uma ciência se dá frente à necessidade de se resolver ou esclarecer questões. Talvez por esta razão, a ortodontia, como ciência, foi marcada em seu período inicial pela busca incessante de meios que pudessem corrigir as diversas deformidades dentofaciais. Com o evolver dos tempos, o acúmulo de conhecimento propiciou o surgimento de uma variedade de técnicas e procedimentos terapêuticos destinados a tratar os diversos tipos de más oclusões. Foi então que a preocupação básica de se desenvolver métodos terapêuticos se derivou para o desafio de melhorar a qualidade dos resultados do tratamento. Continuando nesta escala gradativa de aprimoramento, atualmente tem-se preocupado não apenas com a obtenção de resultados cada vez melhores, mas também com a possibilidade de se alcançá-los num menor intervalo de tempo. Esta aspiração representa a busca atual pela eficiência do tratamento.

A qualidade satisfatória dos resultados não retrata a eficiência do tratamento; é preciso que ela seja obtida num intervalo de tempo que satisfaça às expectativas do profissional e do paciente. Quando se diz que um tratamento foi eficiente, esta afirmação, em geral, não está baseada em nenhuma mensuração ${ }^{50,111,146}$ que possa, de alguma forma, exprimir o grau de eficiência, permanecendo como um julgamento subjetivo. A aplicação de um índice de eficiência permitiu avaliar e comparar de maneira concreta e objetiva o grau de eficiência dos dois protocolos utilizados neste estudo. 
A obtenção de um índice de eficiência significativamente maior no grupo tratado com extrações de dois pré-molares superiores decorreu não apenas dos melhores resultados do tratamento, mas também do menor tempo despendido para alcançá-los, ressaltando o maior grau de eficiência deste protocolo de tratamento (tabela 10).

Cabe ressaltar que o tempo de tratamento do grupo com extrações, utilizado no cálculo do índice de eficiência da tabela 6 , não desconsiderou os pacientes replanejados que apresentavam um tempo de tratamento significativamente aumentado. Portanto, o índice é coerente em mostrar que diante de um mesmo tempo de tratamento, o protocolo de tratamento mais eficiente é aquele capaz de gerar os melhores resultados (tabela 6).

Quando apenas o subgrupo de pacientes não replanejados foi considerado, o grau de eficiência do tratamento com extrações tornou-se expressivamente aumentado tanto em relação ao protocolo sem extrações quanto em relação ao tratamento com extrações do subgrupo replanejado (tabela 10), ressaltando que o replanejamento, por si, compromete a eficiência do tratamento. Caso este comprometimento não se expresse na menor qualidade dos resultados, impreterivelmente se expressará no maior tempo de tratamento ${ }^{191}$.

Uma vez que a necessidade de correção da relação molar, inerente ao protocolo sem extrações, foi o fator que mais comprometeu os resultados e prolongou a duração do tratamento, pode-se presumir que a eficiência dos métodos utilizados para a correção desta discrepância requer, 
em geral, um maior grau de colaboração do paciente, mesmo quando aplicados em pacientes na fase ativa de crescimento.

\subsection{Avaliação dos índices oclusais}

Para investigar a hipótese de que o grau de discrepância ântero-posterior presente ao final do tratamento foi o fator que mais influenciou a variação do índice PAR ao final do tratamento, este índice foi desmembrado em seus diversos componentes (oclusão posterior, overjet, overbite, apinhamento e linha média). A análise de regressão múltipla, aplicada aos componentes do índice PAR demonstrou que a discrepância ântero-posterior foi o componente que mais explicou a variação deste índice ao final do tratamento (tabela 14). Além disso, a comparação intergrupos de cada um dos componentes permitiu concluir que o grau de discrepância ântero-posterior remanescente no grupo tratado sem extrações foi significativamente maior, sendo que os demais componentes tenderam a alcançar graus de correção semelhantes entre os grupos (tabela 15). Estes resultados respaldam a hipótese inicial e ratificam as afirmações de outros estudos sobre a dificuldade imposta aos tratamentos sempre que a relação molar precisa ser amplamente alterada ${ }^{47,111,113,124,207,214,216}$.

Embora a utilização do índice PAR seja, atualmente, mais difundida na literatura em relação ao IPT, o elevado coeficiente de correlação observado entre estes dois índices (tabela 16), demonstrou que ambos apresentam graus de sensibilidade semelhantes para identificar os 
desvios da oclusão em relação à normalidade e as mudanças oclusais decorrentes do tratamento ortodôntico. Esta equivalência na capacidade de avaliação dos índices IPT e PAR foi também constatada quando os percentuais de melhora retratados por estes índices mostraram-se semelhantes ao serem comparados por meio do teste $t$ (tabela 17).

A ausência de avaliação da linha média pelo $\mathrm{IPT}^{94}$ e a desconsideração do apinhamento inferior pelo índice $\mathrm{PAR}^{65}$ demonstra que o conjunto de características oclusais analisadas por um índice difere em certo grau do total de relações oclusais avaliadas pelo outro. Portanto, podese dizer que a associação dos índices oclusais IPT e PAR permitiu avaliar com um grau de sensibilidade semelhante um maior número de características oclusais, aumentando a confiabilidade dos resultados.

\subsection{Considerações Clínicas}

Embora já exista uma certa visualização clínica do menor grau de dificuldade presente na correção da Classe II completa, tratada com extrações de dois primeiros pré-molares superiores $8,47,113,114,124,128$, muitos casos que poderiam ser satisfatoriamente tratados desta forma são, por vezes, submetidos a protocolos de tratamento sem extrações, dificultando, quando não, impossibilitando a correção desta má oclusão ${ }^{111,216}$. As duas principais conseqüências desta falta de acuidade clínica no planejamento dos casos mais severos de Classe II estão retratadas neste estudo, assim como nos trabalhos de JANSON et al. ${ }^{113}$ e MARIA ${ }^{140}$, pelo maior grau de 
comprometimento da qualidade de finalização e pelo aumento significativo no tempo de tratamento e percentual de replanejamento.

O tratamento sem extrações da má oclusão de Classe II completa, requer um maior grau de colaboração do paciente ${ }^{8,37,57,76,111,113,132,216}$, resultando num menor percentual de sucesso em relação ao tratamento com extrações de pré-molares superiores ${ }^{111,161,216}$. Além disso, os resultados do tratamento sem extrações são significativamente influenciados pelo fator crescimento ${ }^{16,50,72,74,76,102,118,155,179}$, tornando-se tanto mais limitado quanto menor for a quantidade de crescimento remanescente. Sendo assim, este protocolo de tratamento deveria ser indicado com cautela nos casos mais severos de Classe II, mesmo quando o paciente ainda se encontra na fase ativa de crescimento e, se possível, evitado na ausência de crescimento. Ressalta-se, ainda, que todos os esforços engendrados para se obter uma correção satisfatória da má oclusão de Classe II sem extrações, num paciente com reduzido potencial de crescimento, tende a produzir benefícios estéticos e funcionais semelhantes em relação ao tratamento com extrações de dois pré-molares superiores. Isto porque a relação molar de Classe II não compromete funcionalmente a oclusão ${ }^{47,48,64,124,130,148,224}$ e os efeitos estéticos obtidos da correção com duas extrações superiores foi considerado superior àqueles obtidos dos tratamentos sem e com quatro extrações ${ }^{45}$. Até mesmo a argumentação de que esta abordagem terapêutica da Classe II evita as extrações de dentes é pouco sustentada, pois o tratamento sem extrações exigirá um certo grau de distalização de todo o arco superior, aumentando 
significativamente a probabilidade de impacção dos terceiros molares $^{55,83,163,167,219}$ cuja remoção cirúrgica envolverá um maior risco ao paciente e ônus ao tratamento do que a extração de dois pré-molares superiores. Por outro lado, extrações realizadas no arco superior poderão favorecer ou, no mínimo, não prejudicar a erupção dos terceiros molares $^{125,163,214}$.

Considera-se que o apinhamento inferior e a discrepância cefalométrica constituem os dois principais fatores que determinam a necessidade de extrações no arco inferior ${ }^{23,89,91,108,185,203}$. Porém, a atual tendência de não se realizar extrações com a intenção precípua de se corrigir a discrepância cefalométrica ${ }^{89,91,113,147,186}$, somada às recentes constatações de que pequenos desgastes interproximais ou protrusões dos incisivos não comprometem a saúde dos tecidos nem a estabilidade do tratamento ${ }^{1,5,29,47,110,134,135,190,194}$, têm corroborado para que uma maior quantidade de casos sejam tratados sem a necessidade de extrações no arco inferior. A ausência de extrações no arco inferior remete as possibilidades de tratamento da má oclusão de Classe II a dois principais protocolos, ou seja, o tratamento sem extrações e o tratamento com extrações de dois pré-molares superiores. Porém, na literatura prevalece uma certa resistência ao tratamento com extrações superiores em pacientes na fase de crescimento, restringindo a aplicação deste protocolo aos pacientes adultos ${ }^{47,64,155,161,181,214}$. Esta conduta mais parece uma atitude condicionada do que uma decisão baseada em evidências científicas. Existem evidências para sustentar a aplicação destes dois protocolos de 
tratamento durante a fase ativa de crescimento, além do que, o protocolo sem extrações irá imprimir sempre um maior nível de dificuldade ao tratamento da Classe II completa ${ }^{8,111,216}$. Talvez a melhor justificativa para 0 tratamento da Classe II, sem extrações esteja fundamentada na possibilidade de redirecionamento do crescimento no intuito de corrigir as alterações estruturais mais freqüentes da má oclusão de Classe II que são a retrusão mandibular e/ou protrusão maxilar ${ }^{19}$. Segundo vários autores a normalização da relação ântero-posterior dos maxilares, nos casos de má oclusão de Classe II, permitiria a melhora da discrepância sagital entre os arcos além de prover maior estabilidade aos resultados do tratamento e uma condição estética mais satisfatória ${ }^{19,90,137,222}$. Contudo, trabalhos recentes demonstram que os resultados do tratamento ortopédico são predominantemente dentoalveolares ${ }^{28,66,68,87,102}$. Sendo assim, a aplicação deste protocolo de tratamento com a intenção precípua de normalizar a relação dos maxilares e prover mais estabilidade e estética aos resultados parece infundada. Isto porque, pacientes com má oclusão de Classe II tratados ortopedicamente apresentam graus variados de recidiva da correção e as alterações estéticas e estruturais não são mais satisfatórias do que aquelas obtidas apenas ortodonticamente $\mathrm{e}^{15,68,72,86,118,137,151,216}$.

Portanto, considerando os efeitos predominantemente dentoalveolares dos tratamentos ortopédicos ${ }^{28,66,68,87,102}$, especula-se que as alterações advindas do tratamento da Classe II sem extrações, utilizando-se apenas forças extrabucais, tendem a se assemelhar àquelas obtidas com extrações de dois pré-molares superiores quando o AEB é utilizado como 
único meio de manter a relação de Classe II dos molares. Isto porque a quantidade de retração anterior superior será sempre limitada pela posição ântero-posterior dos incisivos inferiores que tende a sofrer alterações semelhantes em ambos os protocolos de tratamento.

Seguindo este mesmo raciocínio, se o tratamento da Classe II sem extrações tende a produzir alterações semelhantes, e predominantemente dentárias, quando realizado com aparelhos funcionais ou com aparelhos fixos associados a elásticos de Classe II $^{66,68,72,86,102,118}$, pode-se supor, por analogia, que o tratamento com duas extrações superiores, quando associado a elásticos de Classe II promova alterações similares. Isto porque nos casos com extrações superiores a utilização de elásticos de Classe II mesializa o arco inferior, favorecendo a obtenção da relação de Classe I dos caninos ao mesmo tempo em que compensa a perda de ancoragem no arco superior, mantendo a relação de Classe II dos molares. Sendo assim, ambos os protocolos de tratamento, com e sem extrações, tendem a produzir alterações semelhantes.

Portanto, se alterações similares podem ser alcançadas tratando a má oclusão de Classe II sem extrações ou com extrações de dois pré-molares superiores, a escolha do protocolo de tratamento deveria se basear no grau de eficiência de cada um dos protocolos.

\subsection{Sugestões para novos trabalhos}

- Comparar os grupos cefalometricamente.

- Comparar os grupos quanto à estabilidade da correção. 


$$
\text { CONCLUSÕES }
$$




\section{CONCLUSÕES}

Com fundamento nos resultados apresentados rejeita-se a hipótese nula de que não há diferença no grau de eficiência do tratamento ortodôntico da má oclusão de Classe II completa, realizado sem extrações e com extrações de dois pré-molares superiores. O tratamento com extrações apresentou melhores resultados oclusais num menor tempo de tratamento, atestando o seu maior grau de eficiência quando comparado ao tratamento realizado sem extrações. Constatou-se, também, que os resultados menos satisfatórios do tratamento da Classe II sem extrações foram relacionados, principalmente, à maior proporção de insucesso na correção da relação ântero-posterior dos arcos dentários. 


\section{REFERÊNCIAS BIBLIOGRÁFICAS}




\section{REFERÊNCIAS BIBLIOGRÁFICAS*}

1 ACKERMAN, J.L.; PROFFIT, W.R. Soft tissues limitations in orthodontics: Treatment planning guidelines. Angle Orthod, v.67, n.5, p.327-36, Oct. 1997.

2 ADIKINS, M.D.; NANDA, R.S.; CURRIER, G.F. Ach perimeter changes on rapid palatal expansion. Am J Orthod Dentofacial Orthop, v.97, n.3, p.194-9, Mar. 1990.

3 AELBERS, C.M.F.; DERMAUT, L.R. Orthopedics in orthodontics; Part I, fiction or reality - a review of the literature. Am J Orthod Dentofacial Orthop, v.110, n.5, p.513-18, Nov. 1996.

4 AL YAMI, E.A.; KUIJPERS-JAGTMAN, A.M.; VAN 'T HOF, M.A. Occlusal outcome of orthodontic treatment. Angle Orthod, v.68, n.5, p.439-44, Oct. 1998.

5 ALLAIS, D.; MELSEN, B. Does labial movement of lower incisor influence the level of the gingival margin? A case-control study of adult orthodontic patients. Eur J Orthod, v.25, n.4, p.343-52, Aug. 2003.

6 ANDERSON, B.D. Multiple extraction patterns in severe discrepancy cases. Angle Orthod, v.45, n.4, p.291-303, Oct. 1975.

7 ANDREWS, L.F. The six keys to normal occlusion. Am J Orthod, v.62, n.3, p.296-309, Sept. 1972.

8 ANDREWS, L.F. The straight wire appliance. Syllabus of philosophy and techniques. 2ed., 1975.

\footnotetext{
* Normas recomendadas para uso no âmbito da Universidade de São Paulo, com base no documento "Referências Bibliográficas: exemplos", emanados do Conselho Supervisor do Sistema Integrado de Bibliotecas da USP, em reunião de 20 de setembro de 1990.
} 
9 ANGLE, E.H. Classificator of malocclusion. Dent Cosmos, v.41, p.248$357,1899$.

10 ARAUJO, E.; SOUKI, M. Bolton anterior tooth size discrepancies among different malocclusion groups. Angle Orthod, v.73, n.3, p.307-13, June 2003.

11 ATHERTON, G.J.; GLENNY, A.M.; O'BRIEN, K. Development and use of a taxonomy to carry out systematic review of the literature on methods described to effect distal movement of maxillary molars. J Orthod, v.29, n.3, p.211-6, Sept. 2002.

12 BACCETTI, T. Early dentofacial features of class II malocculsion: A longitudinal study from the deciduous through the mixed dentition. Am J Orthod Dentofacial Orthop, v.111, n.5, p.502-9, May 1997.

13 BAKER, N.J., et al. Occlusal outcome in patients undergoing orthognathic surgery with internal fixation. Br J Oral Maxillofac Surg, v.37, n.2, p.90-3, Apr. 1999.

14 BALTROMEJUS, S.; RUF, S.; PANCHERZ, H. Effective temporomandibular joint growth and chin position changes: activator versus Herbst treatment. A cephalometric roentgenographic study. Eur J Orthod, v.24, n.6, p.627-37, Dec. 2002.

15 BARRER, J.G.; GHAFARI, J. Silhouete profiles in the assessment of facial esthetics: a comparison of cases treated with various orthodontic appliances. Am J Orthod, v.87, n.5, p.385-91, May 1985.

16 BARTON, S.; COOK, P.A. Predicting functional appliance treatment outcome in Class II malocclusion - a review. Am J Orthod Dentofacial Orthop, v.112, n.3, p.282-6, Sept. 1997.

17 BARTSCH, A., et al. Correlates of objective patient compliance with removable appliance wear. Am J Orthod Dentofacial Orthop, v.104, n.4, p.378-86, Oct. 1993. 
18 BASCIFTCI, F.A.; USUMEZ, S. Effect of extraction and nonextraction treatment on Class I and Class II subjects. Angle Orthod, v.73, n.1, p.36-42, Feb. 2003.

19 BASS, N.M. Orthopedic coordination of dentofacial development in skeletal Class II malocclusion in conjunction with edgewise therapy. Part I. Am J Orthod Dentofacial Orthop, v.84, n.5, p.361-83, Nov. 1983.

20 BAUMRIND, S.; FRANTZ, R. The reliability of head film measurementes.

1. Landmark identification. Am J Orthod, v.60, n.2, p.111-27, Aug. 1971.

21 BAUMRIND, S.; FRANTZ, R. The reliability of head film measurementes.

2. Conventional angular and linear measurements. Am J Orthod, v.60, n.5, p.505-17, Nov. 1971.

22 BAUMRIND, S., et al. The decision to extract: Part 1 - Interclinician agreement. Am J Orthod Dentofacial Orthop, v.109, n.3, p.297-309, Mar. 1996.

23 BAUMRIND, S., et al. The decision to extract: Part II. Analysis of clinicians' stated reasons for extraction. Am J Orthod Dentofacial Orthop, v.109, n.4, p.393-402, Apr. 1996.

24 BECKWITH, F.R., et al. An evaluation of factors affecting duration of orthodontic treatment. Am J Orthod Dentofacial Orthop, v.115, n.4, p.439-47, Apr. 1999.

25 BERGERSEN, E.O. A Longitudinal Study of Anterior Vertical Overbite from Eight to Twenty Years of Age. Angle Orthod, v.58, n.3, p.23756, July 1988.

26 BERNSTEIN, L. Edward H. Angle versus Calvin S. Case: extraction versus nonextraction. Part I. Historical revisionism. Am J Orthod Dentofacial Orthop, v.102, n.5, p.464-70, Nov. 1992. 
27 BERNSTEIN, L. Edward H. Angle versus Calvin S. Case: extraction versus nonextraction. Historical revisionism. Part II. Am J Orthod Dentofacial Orthop, v.102, n.6, p.546-51, Dec. 1992.

28 BERNSTEIN, L.; ULBRICH, R.W.; GIANELLY, A.A. Orthopedics versus orthodontics in Class II treatment: an implant study. Am J Orthod, v.72, n.5, p.549-58, Nov. 1977.

29 BETTERIDGE, M.A. The effects of interdental stripping on the labial segments evaluated one year out of retention. Br J Orthod, v.8, n.4, p.193-7, Oct. 1981.

30 BIRKELAND, K., et al. Evaluation of treatment and post-treatment changes by the PAR Index. Eur J Orthod, v.19, n.3, p.279-88, June 1997.

31 BISHARA, S.E. Textbook of Orthodontics. Philadelphia, W.B. Saunders Company, c2001. 592 p.

32 BISHARA, S.E.; CUMMINS, D.M.; JAKOBSEN, J.R. The morphologic basis for the extraction decision in Class II, Division 1 malocclusions: a comparative study. Am J Orthod Dentofacial Orthop, v.107, n.2, p.129-35, Feb. 1995.

33 BISHARA, S.E.; JAKOBSEN, J.R. Profile changes in patients treated with and without extractions: Assessments by lay people. Am J Orthod Dentofacial Orthop, v.112, n.6, p.639-44, Dec. 1997.

34 BISHARA, S.E., et al. Soft tissue profile changes from 5 to 45 years of age. Am J Orthod Dentofacial Orthop, v.114, n.6, p.698-706, Dec. 1998.

35 BISHARA, S.E., et al. Longitudinal changes in standing height and mandibular parameters between the ages of 8 and 17 years. Am J Orthod, v.80, n.2, p.115-35, Aug. 1981. 
36 BISHARA, S.E.; PETERSON, L.C.; BISHARA, E.C. Changes in facial dimensions and relationships between the ages of 5 and 25 years. Am J Orthod, v.85, n.3, p.238-52, Mar. 1984.

37 BISHARA, S.E.; ZIAJA, R.R. Functional appliances: a review. Am J Orthod Dentofacial Orthop, v.95, n.3, p.250-8, Mar. 1989.

38 BJÖRK, A. Variability and age changes in overjet and overbite. Am J Orthodont, v.39, n.10, p.779-801, Oct. 1953.

39 BJÖRK, A.; KREBS, A.A.; SOLOW, B. A method for epidemiological registration of malocclusion. Acta Odontol Scand, v.22, p.27-41, Feb. 1964.

40 BLAKE, M.; BIBBY, K. Retention and stability: a review of the literature. Am J Orthod Dentofacial Orthop, v.114, n.3, p.299-306, Sept. 1998.

41 BLOCK, M.S.; HOFFMAN, D.R. A new device for absolute anchorage for orthodontics. Am J Orthod Dentofacial Orthop, v.107, n.3, p.251-8, Mar. 1995.

42 BOLEY, J.C., et al. Long-term stability of Class I premolar extraction treatment. Am J Orthod Dentofacial Orthop, v.124, n.3, p.277-87, Sept. 2003.

43 BOWMAN, S.J. One-stage versus two-stage treatment: Are two really necessary? Am J Orthod Dentofacial Orthop, v.113, n.1, p.111-5, Jan. 1998.

44 BOWMAN, S.J. More than lip service: facial esthetics in orthodontics. J Am Dent Assoc, v.130, n.8, p.1773-81, Aug. 1999.

45 BOWMAN, S.J.; JOHNSTON, L.E. The esthetic impact of extraction and nonextraction treatments on Caucasian patients. Angle Orthod, v.70, n.1, p.3-10, Feb. 2000. 
46 BRAMBILLA, A.D. Comparação dos resultados oclusais do tratamento da Classe II realizado com extrações de dois prémolares, com a terapêutica utilizando as extrações de quatro prémolares. Bauru, 2002. 92 p. Dissertação (Mestrado) - Faculdade de Odontologia de Bauru, Universidade de São Paulo.

47 BRYK, C.; WHITE, L.W. The geometry of Class II correction with extractions. J Clin Orthod, v.35, n.9, p.570-9, Sept. 2001.

48 BUCHANAN, I.B., et al. A comparison of the reliability and validity of the PAR index and Summer's occlusal index. Eur J Orthod, v.15, n.1, p.27-31, Feb. 1993.

49 BUSCHANG, P.H.; MARTINS, J. Childhood and adolescent changes of skeletal relationships. Angle Orthod, v.68, n.3, p.199-206, June 1998.

50 CANGIALOSI, T.J., et al. A cephalometric appraisal of edgewise Class II nonextraction treatment with extraoral force. Am $\mathbf{J}$ Orthod Dentofacial Orthop, v.93, n.4, p.315-24, Apr. 1988.

51 CAPELlUTO, E.; LAUWERYNS, I. A Simple Technique for Molar Uprighting. J Clin Orthod, v.41, n.2, p.119-25, Feb. 1997.

52 CELENZA, F.; HOCHMAN, M.N. Absolute anchorage in orthodontics: direct and indirect implant-assisted modolities. J Clin Orthod, v.34, n.7, p.397-402, July 2000.

53 CHANG, H., et al. Effects of activator treatment on Class II, Division 1 malocclusion. J Clin Orthod, v.23, n.8, p.560-3, Aug. 1989.

54 CHEW, M.T.; SANDHAM, A. Effectiveness and duration of two-arch fixed appliance treatment. Aust Orthod J, v.16, n.2, p.98-103, July 2000.

55 CHIPMAN, M. Second and third molars: their role in orthodontic therapy. Am J Orthod, v.47, n.7, p.498-520, July 1961. 
56 CLAMAN, L.; ALFARO, M.A.; MERCADO, A. An interdisciplinary approach for improved esthetic results in the anterior maxilla. $\mathbf{J}$ Prosthet Dent, v.89, n.1, p.1-5, Jan. 2003.

57 COLE, W.A. Accuracy of patient reporting as an indication of headgear compliance. Am J Orthod Dentofacial Orthop, v.121, n.4, p.419-23, Apr. 2002.

58 CREEKMORE, T.D.; RADNEY, L.J. Fränkel appliance therapy: orthopedic or orthodontic? Am J Orthod Dentofacial Orthop, v.83, n.2, p.89-108, Feb. 1983.

59 CUCALON, A.; SMITH, R.J. Relationship between compliance by adolescent orthodontic patients and performance on psychological tests. Angle Orthod, v.60, n.2, p.107-14, Summer 1990.

60 DAHLBERG, G. Statistical methods for medical and biological students. New York, Interscience Publications, 1940.

61 DANIELS, C.; RICHMOND, S. The development of the Index of complexity, outcome an need. J Orthod, v.27, n.2, p.149-62, June 2000.

62 DANN, C., et al. Self-concept, Class II malocclusion, and early treatment. Angle Orthod, v.65, n.6, p.411-6, 1995.

63 DE VINCENZO, J. Changes in mandibular length before, during, and after successful orthopedic correction of Class II malocclusions, using a functional appliance. Am J Orthod Dentofacial Orthop, v.99, n.3, p.241-57, Mar. 1991.

64 DEANGELIS, V. Selection of teeth for extraction as an adjunct to orthodontic treatment. J Am Dent Assoc, v.87, n.3, p.610-5, Sept. 1973. 
65 DEGUZMAN, L., et al. The validation of the Peer assessment Rating index for malocclusion severity and treatment difficulty. Am $\mathbf{J}$ Orthod Dentofacial Orthop, v.107, n.2, p.172-6, Feb. 1995.

66 DERMAUT, L.R.; AELBERS, C.M.F. Orthopedics in orthodontics: Fiction or reality. A review of the literature - part II. Am J Orthod Dentofacial Orthop, v.110, n.6, p.667-71, Dec. 1996.

67 DIBIASE. The timming of orthodontic treatment. Dent Update, v.29, n.9, p.434-41, Nov. 2002.

68 DRAGE, K.J.; HUNT, N.P. Overjet relapse following functional appliance therapy. Br J Orthod, v.17, n.3, p.205-13, Aug. 1990.

69 DROBOCKY, O.B.; SMITH, R.J. Changes in facial profile during orthodontic treatment with extraction of four first premolars. Am J Orthod Dentofacial Orthop, v.95, n.3, p.220-30, Mar. 1989.

70 DYER, G.S.; HARRIS, E.F.; VADEN, J.L. Age effects on orthodontic treatment: Adolescents contrasted with adults. Am J Orthod Dentofacial Orthop, v.100, n.6, p.523-30, Dec. 1991.

71 DYKEN, R.A.; SADOWSKY, P.L.; HURST, D. Orthodontic outcomes assessment using the Peer Assessment Rating Index. Angle Orthod, v.71, n.3, p.164-9, June 2001.

72 EDWARDS, J.G. Orthopedics effects with "conventional" fixed orthodontic appliances: a preliminary report. Am J Orthod Dentofacial Orthop, v.84, n.4, p.275-91, Oct. 1983.

73 ELLIS, P.E.; BENSON, P.E. Does articulating estudy casts make a difference to treatment planning. J Orthod, v.30, n.1, p.45-9, Mar. 2003. 
74 ENOKI, C.; MATSUMOTO, M.A.N.; FERREIRA, J.T.L. Orthopedic cervical headgear in CLass II treatment: Case report. Braz Dent $\mathbf{J}$, v.14, n.1, p.63-6, 2003.

75 FALTIN, K., et al. Long-term effectiveness and treatment timing for bionator therapy. Angle Orthod, v.73, n.3, p.221-30, June 2003.

76 FERREIRA, S.L. Class II Division 2 deep overbite malocclusion correction with nonextraction therapy and Class II elastics. Am J Orthod Dentofacial Orthop, v.114, n.2, p.166-75, Aug. 1998.

77 FINK, D.F.; SMITH, R.J. The duration of orthodontic treatment. Am J Orthod Dentofacial Orthop, v.102, n.1, p.41-51, July 1992.

78 FISK, R.O. When malocclusion concerns the public. J Can Dent Assoc, v.26, n.7, p.397-412, July 1960.

79 FOLEY, T.F.; MAMANDRAS, A.H. Facial growth in females 14 to 20 years of age. Am J Orthod, v.101, n.3, p.248-54, Mar. 1992.

80 FRASER, E.J. Principles of extraction therapy. Angle Orthod, v.26, n.4, p.241-2, Oct. 1956.

81 GABRIEL, H.F. Psychology of the use of the headgear. Angle Orthod, v.35, n.4, p.320-5, Oct. 1965.

82 GHAFARI, J.; LOCKE, S.A.; BENTLEY, J.M. Longitudinal evaluation of the treatment priority. Am J Orthod Dentofacial Orthop, v.96, n.5, p.382-9, Nov. 1989.

$83 \mathrm{GHOSH}$, J.; NANDA, R.S. Evaluation of an intraoral maxillary molar distalization technique. Am J Orthod Dentofacial Orthop, v.110, n.6, p.639-46, Dec. 1996. 
84 GIANCOTTI, A. Nonextraction treatment of a high-angle Class II malocclusion: a case report. Am J Orthod Dentofacial Orthop, v.117, n.6, p.721-7, June 2000.

85 GIANELLY, A.A.; BEDNAR, J.; DIETZ, V.S. Japanese Ni-Ti coils used to move molars distally. Am J Orthod Dentofacial Orthop, v.99, n.6, p.564-66, June 1991.

86 GIANELLY, A.A.; BERNSTEIN, L. A comparison of Class II treatment changes noted with the light wire, edgewise, and Fränkel appliances. Am J Orthod Dentofacial Orthop, v.86, n.4, p.269-76, Oct. 1984.

87 GIANELLY, A.A.; VALENTINI, V. The role of "orthopedics" and orthodontics in the treatment of Class II, Division malocclusion. Am J Orthod, v.69, n.6, p.669-78, June 1976.

88 GOTTLIEB, E.L.; NELSON, A.H.; VOGELS, D.S. 1990 JCO study of orthodontic diagnosis and treatment procedures. Part 1. Results and trends. J Clin Orthod, v.25, n.3, p.145-55, Mar. 1990.

89 GRABER, T.M. Current orthodontic concepts and techniques. Philadelphia, Saunders, v.1, 1969. 998 p.

90 GRABER, T.M.; RAKOSI, T.; PETROVIC, A.G. Ortpedia dentofacial com aparelhos funcionais. 2ed. Rio de Janeiro, Guanabara Koogan, 1999. 500 p.

91 GRABER, T.M.; VANARSDALL, R.L. Orthodontics: current principles and techniques. 2ed. St. Louis, Mosby, 1994. 37-40 p.

92 GRABER, T.M.; VANARSDALL, R.L. Ortodontia, princípios e técnicas atuais. 2ed. Rio de Janeiro, Guanabara Koogan, 1996. 897 p.

93 GRACIANO, J.T.A. Características oclusais e cefalométricas de pacientes com Classe II, Divisão 1, tratados com e sem extrações de dois pré-molares superiores. Bauru, 2003. 161 p. Dissertação 
(Mestrado) - Faculdade de Odontologia de Bauru, Universidade de São Paulo.

94 GRAINGER, R.M. Orthodontic treatment priority index. Vital Health Stat, v.25, n.2, p.1-49, Dec. 1967.

95 GRAY, A.S.; DEMIRJIAN, A. A indexing occlusion for dental public health programs. Am J Orthod, v.72, n.2, p.191-7, Aug. 1977.

96 HÄGG, U.; DU, X.; RABIE, A.B.M. Initial and late treatment effects of headgear-Herbst appliance with mandibular step-by-step advancement. Am J Orthod Dentofacial Orthop, v.122, n.5, p.47785, Nov. 2002.

97 HÄGG, U.; TARANGER, J. Maturation indicators and the pubertal growth spurt. Am J Orthod, v.82, n.4, p.299-309, Oct. 1982.

98 HAMDAN, A.M.; ROCK, W.P. An appraisal of the peer assessment rating (PAR) index and a suggested new weighting system. Eur J Orthod, v.21, n.2, p.181-92, Apr. 1999.

99 HAN, U.K., et al. Consistency of orthodontic treatment decisions relative to diagnostic records. Am J Orthod Dentofacial Orthop, v.100, n.3, p.212-9, Mar. 1991.

100 HARALABAKIS, N.B.; HALAZONETIS, D.J.; SIFAKAKIS, I.B. Activator versus cervical headgear: superimpositional cephalometric comparison. Am J Orthod Dentofacial Orthop, v.123, n.3, p.296305, Mar. 2003.

101 HARRIS, E.F.; DYER, G.S.; VADEN, J.L. Age effects on orthodontic treatment: skeletodental assessments from the Johnston analysis. Am J Orthod Dentofacial Orthop, v.100, n.6, p.531-6, Dec. 1991.

102 HASHIM, H.A. Analysis of activator treatment changes. Aust Orthod J, v.12, n.2, p.100-4, Oct. 1991. 
103 HEUSDENS, M.; DERMAUT, L.R.; VERBEECK, R. The effetct of tooth size discrepancy on occlusion: An experimental study. Am J Orthod Dentofacial Orthop, v.117, n.2, p.184-91, Feb. 2000.

104 HILL, P.A. The prevalence and severity of malocclusion and the need for orthodontic treatment in 9-, 12-, and 15 - year -old Glasgow schoolchildren. Br J Orthod, v.19, n.2, p.87-96, May 1992.

105 HOLMAN, J.K., et al. A assessment of extraction versus nonextraction orthodontic treatment using the peer assessment rating (PAR) index. Angle Orthod, v.68, n.6, p.527-34, Dec. 1998.

106 HOUAISS, A. Dicionário eletrônico Houaiss da língua portuguesa. versão 1.0, Editora Objetiva, 2001.

107 HOUSTON, W.J.B. The analysis of errors in orthodontics measurements. Am J Orthod, v.83, n.5, p.382-90, May 1983.

108 HOWE, R.P.; MCNAMARA, J.A.; O'CONNOR, K.A. An examination of of dental crowding and its relationship to tooth size an arch dimension. Am J Orthod, v.83, n.5, p.363-73, May 1983.

109 HUBBARD, G.W.; NANDA, R.S.; CURRIER, G.F. A cephalometric evaluation of nonextraction cervical headgear treatment in Class II malocclusions. Angle Orthod, v.64, n.5, p.359-70, Oct. 1994.

110 HUDSON, A.L. A study of the effects of mesiodistal reduction of mandibular anterior teeth. Am J Orthod, v.42, n.8, p.615-24, Aug. 1956.

111 JACOBS, T.; SAWAENGKIT, P. National Institute of Dental and Craniofacial Research efficacy trials of bionator Class II treatment: A review. Angle Orthod, v.72, n.6, p.571-75, Dec. 2002. 
112 JAMISON, J.E., et al. Longitudinal changes in the maxilla and the maxillary-mandibular relationship between 8 and 17 years of age. Am J Orthod, v.82, n.3, p.217-30, Sept. 1982.

113 JANSON, G., et al. Class II treatment success rate in 2 - and 4 premolar extraction protocols. Am J Orthod Dentofacial Orthop, v.125, n.4, p.472-9, Apr. 2004.

114 JANSON, G., et al. Class II subdivision treatment success rate with symmetric and asymmetric extraction protocols. Am J Orthod Dentofacial Orthop, v.124, n.3, p.257-64, Sept. 2003.

115 JANSON, G., et al. Unusual orthodontic retreatment. Am J Orthod Dentofacial Orthop, v.123, n.4, p.468-75, Apr. 2003.

116 JANSON, G., et al. Occlusal changes of Class II malocclusion treatment between Fränkel and the Eruption Guidance Appliances. Angle Orthod, v.74, n.4, p.521-5, Oct. 2004.

117 JOHNSTON, L.E. Answers in search of questioners. Am J Orthod Dentofacial Orthop, v.121, n.6, p.552-3, June 2002.

118 JONHSTON, L. Growth and the Class II patient: Rendering unto Caesar. Semin Orthod, v.4, n.1, p.59-62, Mar. 1998.

119 KARLSEN, A.T. Craniofacial characteristics in children with Angle Class Il div. 2 malocclusion combined with extreme deep bite. Angle Orthod, v.64, n.2, p.123-30, Apr. 1994.

120 KARLSEN, A.T.; KROGSTAD, O. Morphology and growth in convex profile facial patterns: a longitudinal study. Angle Orthod, v.69, n.4, p.334-44, Aug. 1999.

121 KEELING, S.D., et al. A multivariate approach to analyzing the relation between occlusion and craniofacial morphology. Am J Orthod Dentofacial Orthop, v.95, n.4, p.297-305, Apr. 1989. 
122 KEIM, R.G., et al. 2002 JCO study of orthodontic diagnosis and treatment procedures. Part 1. Results and trends. J Clin Orthod, v.36, n.10, p.553-68, Oct. 2002.

123 KELES, A.; SAYINSU, K. A new approach in maxillary molar distalization: intraoral bodily molar distalizer. Am J Orthod Dentofacial Orthop, v.117, n.1, p.39-48, Jan. 2000.

124 KESSEL, S.P. The rationale of maxillary premolar extraction only in Class II therapy. Am J Orthod, v.49, n.4, p.276-93, Apr. 1963.

$125 \mathrm{KIM}$, J.C., et al. Cephalometric variables as predictors of Class II treatment outcome. Am J Orthod Dentofacial Orthop, v.118, n.6, p.636-40, Dec. 2000.

$126 \mathrm{KIM}, \mathrm{T}$., et al. Prevalence of third molar impaction in orthodontic patients treated nonextraction and with extraction of 4 premolars. Am J Orthod Dentofacial Orthop, v.123, n.2, p.138-45, Feb. 2003.

127 KING, G.J., et al. Orthodontists' perceptions of the impact of phase 1 treatment for Class II malocclusion on phase II needs. J Dent Res, v.78, n.11, p.1745-53, Nov. 1999.

128 KLAPPER, L., et al. The influence of extraction and nonextraction orthodontic treatment on brachyfacial and dolichofacial growth patterns. Am J Orthod Dentofacial Orthop, v.101, n.5, p.425-30, May 1992.

129 KLOCKE, A.; NANDA, R.S.; KAHL-NIEKE, B. Skeletal Class II patterns in the primary dentition. Am J Orthod Dentofacial Orthop, v.121, n.6, p.596-601, June 2002.

130 KREMENAK, C.R., et al. Orthodontic risk factors for temporomandibular disorders (TMD). I: Premolar extractions. Am J Orthod Dentofacial Orthop, v.101, n.1, p.13-20, Jan. 1992. 
131 LEWIS, E.A., et al. Reliability and validity of clinical assessments of malocclusion. Am J Orthod, v.81, n.6, p.473-7, June 1982.

132 LIEBERMAN, A.M.; GAZIT, E. Guides to orthodontic treatment timing. J Am Dent Assoc, v.88, n.3, p.555-62, Mar. 1974.

133 LINKLATER, R.A.; FOX, N.A. The long-term benefits of orthodontic treatment. Br J Orthod, v.192, n.10, p.583-7, May 2002.

134 LITTLE, R.M. Stability and relapse of dental arch alignment. $\mathbf{B r} \mathbf{~ J}$ Orthod, v.17, n.3, p.235-41, Aug. 1990.

135 LITTLE, R.M.; RIEDEL, R.A.; ARTUN, J. An evaluation of changes in mandibular anterior alignment from 10 to 20 years postretention. Am J Orthod Dentofacial Orthop, v.93, n.5, p.423-8, May 1988.

136 LITTLE, R.M.; WALLEN, T.R.; RIEDEL, R.A. Stability and relapse of mandibular anterior alignment-first premolar extraction cases treated by traditional edgewise orthodontics. Am J Orthod, v.80, n.4, p.34965, Oct. 1981.

137 LIVIERATOS, F.A.; JOHNSTON, L.E. A comparison of one-stage and two stage nonextraction alternatives in matched Class II samples. Am J Orthod Dentofacial Orthop, v.108, n.2, p.118-31, Aug. 1995.

138 LUEDTKE, G.L. Preventive orthodontics: early reduction of Class II, Division 1 malocclusion. Am J Orthod, v.63, n.1, p.18-29, Jan. 1973.

139 MACCALL, J.O. A study of malocclusion in pre-school and school children. Dent Items Interest, p.131-3, 1944.

140 MARIA, F.R.T. Estudo do tempo de tratamento de casos tratados ortodonticamente com extrações de dois pré-molares superiores comparados aos de extrações de quatro pré-molares. Bauru, 2002. 111 p. Dissertação (Mestrado) - Faculdade de Odontologia de Bauru, Universidade de São Paulo. 
141 MARTINS, D.R., et al. Atlas de crescimento craniofacial. Bauru, Ed. Santos, 1988. 280 p.

142 MASCARENHAS, A.K.; VIG, K. Comparison of orthdontic treatment outcome in educational and private practice settings. J Dent Educ, v.66, n.1, p.94-9, Jan. 2002.

143 MCGUINNESS, N.J.; MCDONALD, J.P. The influence of operator changes on orthodontic treatment times and results in a postgraduate teaching enviroment. Eur J Orthod, v.20, n.2, p.159-67, Apr. 1998.

144 MCNAMARA, J.A. Components of Class II malocclusion in children 8-10 years of age. Am J Orthod, v.51, n.3, p.177-202, July 1981.

145 MCSHERRY, P.F.; BRADLEY, H. Class II correction-reducing patient compliance: a review of the available techniques. J Orthod, v.27, n.3, p.219-25, Sept. 2000.

146 MELSEN, B.; BOSCH, C. Different approaches to anchorage: A survey and an evaluation. Angle Orthod, v.67, n.1, p.23-30, Feb. 1997.

147 MILLS, J.R.E. Long-term results of proclination of lower incisors. Brit Dent J, v.120, n.8, p.355-63, Apr. 1966.

148 NANGIA, A.; DARENDELILER, M.A. Finishing occlusion in Class II or CLass III molar relation: Therapeutic Class II and III. Aust Orthod J, v.17, n.2, p.89-94, Nov. 2001.

149 NELSON, B.; HANSEN, K.; HÄGG, U. Class II correction in patients treated with Class II elastics and with fixed functional appliances. Am J Orthod Dentofacial Orthop, v.118, n.2, p.142-9, Aug. 2000.

150 O'BRIEN, K.D., et al. The effectiveness of Class II, Division 1 treatment. Am J Orthod Dentofacial Orthop, v.107, n.3, p.329-34, Mar. 1995. 
151 O'NEILL, K.; HARKNESS, M.; KNIGHT, R. Ratings of profile attractiveness after functional appliance treatment. Am J Orthod Dentofacial Orthop, v.118, n.4, p.371-6, Oct. 2000.

152 PANCHERZ, H. Dentofacial orthopedics or orthognatic surgery: Is it a matter of age? Am J Orthod Dentofacial Orthop, v.117, n.5, p.5714, May 2000.

153 PANCHERZ, H.; FISCHER, S. Amount and direction of temporomandibular joint growth changes in Herbst treatment: $A$ cephalometric long-term investigation. Angle Orthod, v.73, n.5, p.493-501, Oct. 2003.

154 PANCHERZ, H.; ZIEBER, K.; HOYER, B. Cephalometric characteristics of Class II division 1 and Class II division 2 malocclusions: A comparative study in children. Angle Orthod, v.67, n.2, p.111-20, Apr. 1997.

155 PAQUETTE, D.E.; BEATTIE, J.R.; JOHNSTON, L.E. A long term comparison of nonextraction and premolar extraction edgewise therapy in "borderline" Class II patients. Am J Orthod Dentofacial Orthop, v.102, n.1, p.1-14, July 1992.

156 PECK, S.; PECK, H. Frequency of tooth extraction in orthodontic treatment. Am J Orthod, v.76, n.5, p.491-6, Nov. 1979.

157 PROFFIT, W.R. Forty-year review of extraction frequencies at a university orthodontic clinic. Angle Orthod, v.64, n.6, p.407-14, Dec. 1994.

158 PROFFIT, W.R.; FIELDS, H.W.; MORAY, L.J. Prevalence of malocclusion and orthodontic treatment need in the United States: estimates from the NHANES-III survey. Int $\mathbf{J}$ Adult Orthodon Orthognath Surg, v.13, n.2, p.97-106, 1998. 
159 PROFFIT, W.R.; PHILLIPS, C.; DANN, C. Who seeks surgicalorthodontic treatment? Int J Adult Orthodon Orthognath Surg, v.5, n.3, p.153-60, 1990.

160 PROFFIT, W.R.; PHILLIPS, C.; DOUVARTZIDIS, N. A comparison of outcomes of orthodontic and surgical -orthodontic treatment of Class II malocclusion in adults. Am J Orthod Dentofacial Orthop, v.101, n.6, p.556-65, June 1992.

161 PROFFIT, W.R., et al. Surgical versus orthodontic correction of skeletal Class II malocclusion in adolescents: Effects and indications. Int $\mathbf{J}$ Adult Orthodon Orthognath Surg, v.7, n.4, p.209-20, 1992.

162 PROFFIT, W.R.; TULLOCH, J.F. Preadolescent Class II problems: treat now or wait? Am J Orthod Dentofacial Orthop, v.121, n.6, p.560-2, June 2002.

163 PUTRICK, L.M. Presença clínica e angulação dos terceiros molares superiores, na má oclusão de Classe II, tratada com e sem extrações de pré-molares superiores. Bauru, 2003. 74 p. Dissertação (Mestrado) - Faculdade de Odontologia de Bauru, Universidade de São Paulo.

164 RABIE, A.B.M.; HÄG, U. Functional appliance therapy accelerates and enhances condylar growth. Am J Orthod Dentofacial Orthop, v.123, n.1, p.40-8, Jan. 2003.

165 RABIE, A.B.M., et al. The correlation between neovascularization an bone formation in teeth condyle during forward mandibular positioning. Angle Orthod, v.72, n.5, p.431-8, Oct. 2002.

166 RABIE, A.B.M.; WONG, L.; TSAI, M. Replicating mesenchymal cells in the condyle an the glenoid fossa during mandibular forward positioning. Am J Orthod Dentofacial Orthop, v.123, n.1, p.49-57, Jan. 2003. 
167 RAPE, W.; JACOBSON, A. Nonextraction treatment of a Class II, Division 1 malocclusion. Am J Orthod Dentofacial Orthop, v.103, n.2, p.99-106, Feb. 1993.

168 REDAHAN, S.; LANGERSTROM, L. Orthodontic treatment outcome: the relationship between anterior dental relations e anterior inter-arch tooth size discrepancy. J Orthod, v.30, n.3, p.237-44, Sept. 2003.

169 REDDY, P., et al. Skeletal and dental changes with nonextraction Begg mechanoterapy in patients with Class II Division 1 malocclusion. Am J Orthod Dentofacial Orthop, v.118, n.6, p.641-8, Dec. 2000.

170 RIBAREVSKI, R., et al. Consistency of orthodontic extraction decisions. Eur J Orthod, v.18, n.1, p.77-80, Feb. 1996.

171 RICHMOND, S., et al. Calibration of dentists in the use of occlusal indices. Community Dent Oral Epidemiol, v.23, n.3, p.173-6, June 1995.

172 RICHMOND, S., et al. The development of the PAR index (Peer assessment rating): reliability and validity. Eur J Orthod, v.14, n.2, p.125-39, Apr. 1992.

173 RICHMOND, S., et al. The PAR (Peer Assessment Rating): methods to determine outcome of orthodontic in terms of improvement and standards. Eur J Orthod, v.14, n.3, p.180-7, June 1992.

174 RICHMOND, S., et al. Orthodontics in the General Dental Services of England and Wales: a critical assessment. Brit Dent J, v.174, n.9, p.315-29, May 1993.

175 ROBB, S.I., et al. Effectiveness and duration of orthodontic treatment in adults and adolescents. Am J Orthod Dentofacial Orthop, v.114, n.4, p.383-6, Oct. 1998. 
176 RONDEAU, B.H. Class II malocclusion in mixed dentition. J Clin Pediatr Dent, v.19, n.1, p.1-11, Fall 1994.

177 ROSSOUW, P.E., et al. A longitudinal evaluation of the anterior border of the dentition. Am J Orthod Dentofacial Orthop, v.104, n.2, p.14652, Aug. 1993.

178 RUNGE, M.E.; MARTIN, J.T.; BUKAI, F. Analysis of rapid maxillary molar distal movement without patient cooperation. Am J Orthod Dentofacial Orthop, v.115, n.2, p.153-7, Feb. 1999.

179 RUNGE, M.E.; SADOWSKY, C. Class II, Division 1 vertical pattern. Am J Orthod Dentofacial Orthop, v.94, n.4, p.271-7, Oct. 1988.

180 RUSHING, E., et al. How dentists perceive the effects of orthodontics extraction on facial appearance. J Am Dent Assoc, v.126, n.6, p.769-72, June 1995.

181 RUSSELL, D.M. Extractions in support of othodontic treatment. NDA Journal, v.45, n.2, p.15-9, June/July 1994.

182 SAELENS, N.A.; SMIT, A.A. Therapeutic changes in extraction versus non-extraction orthodontic treatment. Eur J Orthod, v.20, n.3, p.22536, June 1998.

183 SAIN, J.A. Concept and commentary: Some atypical cases. J Clin Orthod, v.7, n.12, p.763-75, Dec. 1973.

184 SAIN, J.A. Concept and commentary: Some more atypical cases. J Clin Orthod, v.8, n.1, p.43-55, Jan. 1974.

185 SAIN, J.A.S. The extraction-nonextraction decision. J Clin Orthod, v.7, n.10, p.621-36, Oct. 1973. 
186 SARVER, D.M. Appearance-driven diagnosis and treatment planning. American Association of Orthodontics. 101st Anual session, Toronto, Canadá, 2001.

187 SCLARE, R. Orthodontics and school children: a survey of 680 children. Brit Dent J, v.79, n.10, p.278-80, Nov. 1945.

188 SHAW, W.C.; RICHMOND, S.; O'BRIEN, K.D. The use of occlusal indices: A European perspective. Am J Orthod Dentofacial Orthop, v.107, n.1, p.1-10, Jan. 1995.

189 SHAW, W.C., et al. Quality control in orthodontics: indices of treatment need an treatment standards. Brit Dent J, v.170, n.3, p.107-12, Feb. 1991.

190 SHERIDAN, J.J.; HASTINGS, J. Air-rotor stripping and lower incisor extraction treatment. J Clin Orthod, v.26, n.1, p.18-22, Jan. 1992.

191 SHIA, G.J. Treatment overruns. J Clin Orthod, v.20, n.9, p.602-4, Sept. 1986.

192 STALLARD, $\mathrm{H}$. The general prevalence of gross symptoms of malocclusion. Dent Cosmos, v.74, n.1, p.29-37, Jan. 1932.

193 STARNBACH, H.K.; KAPLAN, A. Profile of an excellent orthodontic patient. Angle Orthod, v.45, n.2, p.141-5, Apr. 1975.

194 STROUD, J.L.; ENGLISH, J.; BUSCHANG, P.H. Enamel thickness of the posterior dentition: its implications for nonextraction treatment. Angle Orthod, v.68, n.2, p.141-6, Apr. 1998.

195 SUGAWARA, J. The skeletal anchorage system. J Clin Orthod, v.33, n.12, p.689-96, Dec. 1999.

196 SUMMERS, C.J. A system for identifying and scoring occlusal disorders. Am J Orthod, v.59, n.6, p.552-67, June 1971. 
197 TANG, E.L.K.; WEI, S.H.Y. Assessing treatment effectiveness of removable an fixed orthodontic appliances with the occlusal index. Am J Orthod Dentofacial Orthop, v.98, n.6, p.550-6, Dec. 1990.

198 TANG, E.L.K.; WEI, S.H.Y. Recording and measuring malocclusion: a review of the literature. Am J Orthod Dentofacial Orthop, v.103, n.4, p.344-51, Apr. 1993.

199 TULLOCH, J.F., et al. The effect of early intervention on skeletal pattern in Class II malocclusion: A randomized clinical trial. Am J Orthod Dentofacial Orthop, v.111, n.4, p.391-400, Apr. 1997.

200 TULLOCH, J.F.; PHILLIPS, C.; PROFFIT, W.R. Benefit of early Class II treatment: Progress report of a two-phase randomized clinical trial. Am J Orthod Dentofacial Orthop, v.113, n.1, p.62-72, Jan. 1998.

201 TURBILL, E.A.; RICHMOND, S.; WRIGHT, J.L. The time-factor in orthodontics: what influences the duration of treatments in national health service practices? Community Dent Oral Epidemiol, v.29, n.1, p.62-72, Feb. 2001.

202 TURNER, S.A. Occlusal indices revisited. Br J Orthod, v.17, n.3, p.197-203, Aug. 1990.

203 TWEED, C.H. The Frankfort mandibular incisor angle (FMIA) in orthodontic diagnosis, treatment planning and prognosis. Angle Orthod, v.24, n.3, p.121-69, Jul. 1954.

204 UMEMORI, M. Skeletal anchorage system for open-bite correction. Am J Orthod Dentofacial Orthop, v.115, n.2, p.166-74, Feb. 1999.

205 VADEN, J.L.; HARRIS, E.F.; BEHRENTS, R.G. Adult versus adolescent Class II correction: a comparison - case report. Am J Orthod Dentofacial Orthop, v.107, n.6, p.651-61, June 1995. 
206 VADEN, J.L.; KISER, H.E. Straight talk about extraction and nonextraction: a diferencial diagnostic decision. Am J Orthod Dentofacial Orthop, v.109, n.4, p.445-52, Apr. 1996.

207 VIG, K.W.L., et al. Orthodontic Process and outcome; efficacy studies Strategies for developing process and outcome measures: a new era in orthodontics. Clin Orthod Res, v.1, n.2, p.147-55, Nov. 1998.

208 VIG, P.S., et al. The duration of orthodontic treatment with and without extractions: a pilot study of five selected practices. Am J Orthod Dentofacial Orthop, v.97, n.1, p.45-51, Jan. 1990.

209 VOUDOURIS, J.C.; KUFTINEC, M.M. Improved clinical use of Twinblock and Herbst as a result of radiating viscoelastic forces on the condyle and fossa in treatment and long-term retention: growth relativity. Am J Orthod Dentofacial Orthop, v.117, n.3, p.247-66, Mar. 2000.

210 VOUDOURIS, J.C., et al. Condyle-fossa modifications and muscle interactions during Herbst treatment, Part 2. Results and conclusions. Am J Orthod Dentofacial Orthop, v.124, n.1, p.13-29, July 2003.

211 VOUDOURIS, J.C., et al. Condyle-fossa modifications and muscle interactions during Herbst treatment, Part 1. New technological methods. Am J Orthod Dentofacial Orthop, v.123, n.6, p.604-13, June 2003.

212 WEHRBEIN, H.; FEIFEL, H.; DIEDRICH, P. Palatal implant anchorage reinforcement of posterior teeth: a prospective study. Am J Orthod Dentofacial Orthop, v.116, n.6, p.678-86, Dec. 1999.

213 WEINTRAUB, J.A., et al. The prevalence of orthodontic extractions. Am J Orthod Dentofacial Orthop, v.96, n.6, p.462-6, Dec. 1989.

214 WERTZ, R.A. Diagnosis and treatment planning of unilateral Class II malocclusions. Angle Orthod, v.45, n.2, p.85-94, Apr. 1975. 
215 WEST, K.S.; MCNAMARA, J.A. Changes in the craniofacial complex from adolescence to midadulthood: A cephalometric study. Am J Orthod Dentofacial Orthop, v.115, n.5, p.521-32, May 1999.

216 WHEELER, T.T., et al. Effectiveness of early treatment of Class II malocclusion. Am J Orthod Dentofacial Orthop, v.121, n.1, p.9-17, Jan. 2002.

217 WIESLANDER, L. Long-term effect of treatment with the headgearHerbst applaince in the early mixed dentition. Stability or relapse? Am J Orthod Dentofacial Orthop, v.104, n.4, p.319-29, Oct. 1993.

218 WIESLANDER, L.; LANGERSTROM, L. The effect of activator treatment on Class II malocclusions. Am J Orthod, v.75, n.1, p.20-6, Jan. 1979.

219 WILSON, W.L.; WILSON, R.C. Modular 3D Appliances Problem Solving in Edgewise, Straightwire, and Lightwire Treatment. J Clin Orthod, v.18, n.4, p.272-81, Apr. 1984.

220 WOODS, M.; LEE, D.; CRAWFORD, E. Finishing occlusion, degree of stability and the PAR index. Aust Orthod J, v.16, n.1, p.9-15, Mar. 2000.

221 WOODSIDE, D.G. Do functional appliances have an orthopedic effects? Am J Orthod Dentofacial Orthop, v.113, n.1, p.11-4, Jan. 1998.

222 YOKOTA, S.; MURAKAMI, T.; SHIMIZU, K. A growth control approach to Class II, Division 1 cases during puberty involving the simultaneous application of maxillary growth restriction and mandibular forward induction. Am J Orthod Dentofacial Orthop, v.104, n.3, p.211-23, Sept. 1993.

223 YOUNG, T.M.; SMITH, R.J. Effects of orthodontics on the facial profile: A comparison of changes during nonextraction and four premolar 
extraction treatment. Am J Orthod Dentofacial Orthop, v.103, n.5, p.452-8, May 1993.

224 ZACHRISSON, B.U. JCO Interviews. On excellence in finishing (Part 1). J Clin Orthod, v.20, n.7, p.460-82, July 1986.

225 ZIERHUT, E.C., et al. Long-term profile changes associated with successfully treated extraction and nonextraction Class II Division 1 malocclusion. Angle Orthod, v.70, n.3, p.208-19, June 2000. 


$$
\text { ABSTRACT }
$$




\begin{abstract}
This study compared the efficiency of complete Class II malocclusion treatment with and without extraction of two maxillary premolars. A sample of 112 records from patients with complete Class II malocclusion was obtained from the files of the Orthodontic Department at Bauru Dental School, which comprises a total of 3,592 records. This sample was divided into two groups with the following characteristics: Group 1, comprising 43 patients treated without extractions and an initial mean age of $12.63 \pm 1.45$ years (ranging from 9.39 to 16.03 years); and Group 2, comprising 69 patients treated with extraction of two maxillary premolars and an initial mean age of $13.91 \pm 2.71$ years (ranging from 9.42 to 27.08 years). To compare the efficiency of each treatment protocol, the occlusal outcomes were evaluated on dental casts with the TPI and the PAR occlusal indexes, and the treatment time of each group was calculated on the clinical charts. The treatment efficiency degree was calculated as the ratio between the percentages of occlusal improvement, evaluated through the TPI or PAR, by the treatment time. The occlusal indexes, the treatment time and the treatment protocols efficiency degree of the groups were compared by means of the $t$ test. Results demonstrated that the two maxillary premolar extraction protocol provided better occlusal outcomes, in less time, and therefore a greater treatment efficiency than the non-extraction treatment protocol of complete Class II malocclusion.
\end{abstract}




$$
\text { APÊNDICE }
$$


As tabelas A-1 a A-6 referem-se aos valores individuais de cada variável, para cada paciente, dos grupos 1 e 2 .

TABELA A - 1

\begin{tabular}{|c|c|c|c|c|c|c|c|c|}
\hline & Paciente & $\begin{array}{c}\text { Número } \\
\text { de arquivo }\end{array}$ & Gênero & Grupo & Subgrupo & $\begin{array}{c}\text { Tipo de } \\
\text { Classe II }\end{array}$ & APINF & IDADEI \\
\hline 1. & A. C. G. & $112-E$ & $\mathrm{~F}$ & 1 & $1 \mathrm{~B}$ & 1 & 0 & 12,94 \\
\hline 2. & A. S. S. & $84-P G$ & $\mathrm{~F}$ & 1 & $1 \mathrm{~A}$ & 1 & 0 & 11,90 \\
\hline 3. & A. C.I. & 248 - PG & $\mathrm{F}$ & 1 & $1 \mathrm{~A}$ & 1 & 0 & 12,37 \\
\hline 4. & A. L. O. G. & $176-E$ & $\mathrm{~F}$ & 1 & $1 \mathrm{~B}$ & 1 & 0 & 11,52 \\
\hline 5. & B. S. & 339 - PG & $\mathrm{F}$ & 1 & $1 \mathrm{~A}$ & 2 & 0 & 11,81 \\
\hline 6. & C. L. B. & $368-E$ & $\mathrm{~F}$ & 1 & $1 \mathrm{~B}$ & 1 & 0 & 10,12 \\
\hline 7. & C. A. P. & $397-E$ & $\mathrm{M}$ & 1 & $1 \mathrm{~B}$ & 1 & 0 & 10,84 \\
\hline 8. & C. C. U. & $398-E$ & $\mathrm{M}$ & 1 & $1 \mathrm{~A}$ & 1 & 0 & 13,14 \\
\hline 9. & C. L. C. & $181-A c$ & $\mathrm{~F}$ & 1 & $1 \mathrm{~B}$ & 1 & 0 & 11,67 \\
\hline 10. & C. G. S. C. A. & $444-E$ & M & 1 & $1 \mathrm{~B}$ & 1 & 0 & 13,16 \\
\hline 11. & C. A. S. .S & 304 - PG & $\mathrm{F}$ & 1 & $1 \mathrm{~A}$ & 1 & 0 & 13,59 \\
\hline 12. & D. M. O. & $616-E$ & $\mathrm{~F}$ & 1 & $1 \mathrm{~A}$ & 1 & 0 & 11,45 \\
\hline 13. & D. C. J. & $643-E$ & M & 1 & $1 \mathrm{~A}$ & 1 & 2 & 16,04 \\
\hline 14. & D. D. J. & $648-E$ & M & 1 & $1 \mathrm{~A}$ & 2 & 0 & 14,47 \\
\hline 15. & D. M. & $647-E$ & M & 1 & $1 \mathrm{~B}$ & 1 & 0 & 12,89 \\
\hline 16. & E. W. L. & 307 - PG & M & 1 & $1 \mathrm{~B}$ & 1 & 3 & 13,80 \\
\hline 17. & E. A. S. & $694-E$ & $\mathrm{~F}$ & 1 & $1 \mathrm{~A}$ & 2 & 0 & 11,21 \\
\hline 18. & E. M & 153 - PG & $\mathrm{F}$ & 1 & $1 \mathrm{~A}$ & 1 & 0 & 12,54 \\
\hline 19. & E. N. S. & $741-E$ & $\mathrm{~F}$ & 1 & $1 \mathrm{~A}$ & 1 & 0 & 14,35 \\
\hline 20. & F. A. R. & 759 - E & $\mathrm{F}$ & 1 & $1 \mathrm{~A}$ & 1 & 0 & 10,18 \\
\hline 21. & F. C. & $798-E$ & $\mathrm{M}$ & 1 & $1 \mathrm{~A}$ & 1 & 1 & 13,68 \\
\hline 22. & F. M. A. & 410 - PG & $M$ & 1 & $1 \mathrm{~B}$ & 1 & 0 & 12,79 \\
\hline 23. & G. A. G. & $994-E$ & M & 1 & $1 \mathrm{~B}$ & 1 & 0 & 10,98 \\
\hline 24. & H. C. & $1040-E$ & $M$ & 1 & $1 \mathrm{~B}$ & 2 & 2 & 11,86 \\
\hline 25. & J.A. A. C. & 273 - PG & $M$ & 1 & $1 \mathrm{~A}$ & 2 & 0 & 15,68 \\
\hline 26. & J. C.P. & 223 - PG & $\mathrm{M}$ & 1 & $1 \mathrm{~A}$ & 1 & 7 & 13,56 \\
\hline 27. & J. D. & $1173-E$ & $\mathrm{~F}$ & 1 & $1 \mathrm{~B}$ & 1 & 1 & 14,30 \\
\hline 28. & J. S. G. & $755-\mathrm{Ac}$ & $\mathrm{F}$ & 1 & $1 \mathrm{~B}$ & 1 & 0 & 13,96 \\
\hline 29. & L. F. M. & $355-A c$ & $\mathrm{~F}$ & 1 & $1 \mathrm{~A}$ & 1 & 0 & 14,37 \\
\hline 30. & L. B. P. & 384 - PG & $\mathrm{F}$ & 1 & $1 \mathrm{~B}$ & 1 & 0 & 11,08 \\
\hline 31. & L. G. B. & $1406-E$ & $\mathrm{M}$ & 1 & $1 \mathrm{~B}$ & 1 & 0 & 12,91 \\
\hline 32. & M. G. S. & $1439-E$ & M & 1 & $1 \mathrm{~A}$ & 2 & 0 & 12,91 \\
\hline 33. & M. M. L. & $1471-E$ & $\mathrm{M}$ & 1 & $1 \mathrm{~B}$ & 1 & 0 & 11,94 \\
\hline 34. & M. A. C. & 144 - PG & $\mathrm{M}$ & 1 & $1 \mathrm{~A}$ & 1 & 2 & 12,39 \\
\hline 35. & M. T. & $1525-E$ & $\mathrm{M}$ & 1 & $1 \mathrm{~B}$ & 1 & 0 & 11,91 \\
\hline 36. & M. L. C. & 7 - PG & $\mathrm{F}$ & 1 & $1 \mathrm{~A}$ & 1 & 0 & 12,77 \\
\hline 37. & N. C. & $1672-E$ & $\mathrm{~F}$ & 1 & $1 \mathrm{~A}$ & 1 & 0 & 14,42 \\
\hline 38. & N. H. G. & $1676-E$ & $\mathrm{~F}$ & 1 & $1 \mathrm{~B}$ & 1 & 0 & 9,40 \\
\hline 39. & P. C. G. & $1730-E$ & $\mathrm{~F}$ & 1 & $1 \mathrm{~A}$ & 2 & 5 & 12,26 \\
\hline 40. & P. M. C. & $1777-E$ & $\mathrm{~F}$ & 1 & $1 \mathrm{~B}$ & 1 & 0 & 10,53 \\
\hline 41. & R. H. C. & 644 - PG & $\mathrm{M}$ & 1 & $1 \mathrm{~B}$ & 1 & 0 & 13,67 \\
\hline 42. & V. L. U. V. & 552 - PG & M & 1 & $1 \mathrm{~A}$ & 1 & 0 & 13,62 \\
\hline 43. & W. M. L. & 1201 - PG & $\mathrm{M}$ & 1 & $1 \mathrm{~B}$ & 1 & 0 & 12,40 \\
\hline 44. & A. L. & $218-P G$ & $\mathrm{~F}$ & 2 & $2 \mathrm{~B}$ & 1 & 0 & 14,58 \\
\hline 45. & A. B. J. & $43-E$ & $\mathrm{M}$ & 2 & $2 \mathrm{~B}$ & 1 & 0 & 15,00 \\
\hline
\end{tabular}


TABELA A - 2

\begin{tabular}{|c|c|c|c|c|c|c|c|c|}
\hline & Paciente & $\begin{array}{c}\text { Número } \\
\text { de arquivo }\end{array}$ & Gênero & Grupo & Subgrupo & $\begin{array}{l}\text { Tipo de } \\
\text { Classe II }\end{array}$ & APINF & IDADEI \\
\hline 46. & A. M. & $61-E$ & $\mathrm{~F}$ & 2 & $2 \mathrm{~B}$ & 2 & 0 & 11,92 \\
\hline 47. & A. M. G. & $71-E$ & $\mathrm{M}$ & 2 & $2 \mathrm{~A}$ & 1 & 3 & 13,00 \\
\hline 48. & A. M. & $72-E$ & $\mathrm{M}$ & 2 & $2 \mathrm{~A}$ & 1 & 0 & 14,33 \\
\hline 49. & A. O. R. & $123-E$ & $\mathrm{~F}$ & 2 & $2 \mathrm{~A}$ & 1 & 0 & 11,58 \\
\hline 50. & A. L. R. D. & $174-E$ & $\mathrm{~F}$ & 2 & 2B & 1 & 0 & 11,42 \\
\hline 51. & A. P. L. & 143 - PG & $\mathrm{F}$ & 2 & $2 \mathrm{~B}$ & 1 & 0 & 12,83 \\
\hline 52. & A. G. B. & $231-E$ & $\mathrm{M}$ & 2 & $2 \mathrm{~A}$ & 1 & 0 & 14,67 \\
\hline 53. & A. L. B. & $234-E$ & $\mathrm{M}$ & 2 & $2 \mathrm{~A}$ & 1 & 0 & 11,50 \\
\hline 54. & B. B. A. & $328-E$ & $\mathrm{~F}$ & 2 & $2 \mathrm{~A}$ & 1 & 3 & 18,50 \\
\hline 55. & B. L. L. & $346-E$ & $\mathrm{M}$ & 2 & $2 \mathrm{~B}$ & 2 & 2 & 11,58 \\
\hline 56. & B. T. & $52-A C$ & $\mathrm{M}$ & 2 & $2 \mathrm{~B}$ & 1 & 0 & 14,08 \\
\hline 57. & C. S. Z. & 498 - PG & $\mathrm{F}$ & 2 & $2 \mathrm{~B}$ & 2 & 3 & 11,33 \\
\hline 58. & C. R. M. F. & 411- E & $\mathrm{M}$ & 2 & $2 \mathrm{~A}$ & 1 & 0 & 13,67 \\
\hline 59. & D. B. P. & $702-A C$ & $\mathrm{M}$ & 2 & $2 \mathrm{~B}$ & 1 & 0 & 15,17 \\
\hline 60. & D. H. D. & $76-A C$ & $\mathrm{M}$ & 2 & $2 \mathrm{~A}$ & 1 & 2 & 15,25 \\
\hline 61. & E. J. D. & $656-E$ & $\mathrm{M}$ & 2 & $2 \mathrm{~A}$ & 1 & 3 & 13,67 \\
\hline 62. & E. K. & $667-E$ & $M$ & 2 & $2 \mathrm{~A}$ & 2 & 0 & 13,75 \\
\hline 63. & E. S. P. & $671-E$ & $\mathrm{M}$ & 2 & $2 \mathrm{~A}$ & 2 & 0 & 15,08 \\
\hline 64. & E. A. M. & $710-E$ & $\mathrm{M}$ & 2 & $2 \mathrm{~A}$ & 1 & 0 & 14,67 \\
\hline 65. & E. C. D. & $185-\mathrm{Ac}$ & $\mathrm{F}$ & 2 & $2 \mathrm{~A}$ & 1 & 0 & 14,33 \\
\hline 66. & G. A. S. & $432-A c$ & $\mathrm{~F}$ & 2 & $2 \mathrm{~A}$ & 1 & 0 & 16,50 \\
\hline 67. & H. A. J. S. & $1028-E$ & $\mathrm{M}$ & 2 & $2 \mathrm{~A}$ & 1 & 2 & 12,67 \\
\hline 68. & H. S. S. & $1035-E$ & $\mathrm{~F}$ & 2 & $2 \mathrm{~A}$ & 1 & 0 & 12,42 \\
\hline 69. & I. E. B. P. C. & $1058-E$ & $\mathrm{~F}$ & 2 & $2 \mathrm{~A}$ & 2 & 2 & 27,08 \\
\hline 70. & I. A. F. M. & $1066-E$ & $\mathrm{M}$ & 2 & $2 \mathrm{~A}$ & 2 & 3 & 14,67 \\
\hline 71. & J.A. T. & $710-A c$ & $M$ & 2 & $2 \mathrm{~A}$ & 1 & 3 & 11,42 \\
\hline 72. & J. T. J. & $168-A c$ & $\mathrm{M}$ & 2 & $2 \mathrm{~B}$ & 2 & 0 & 14,00 \\
\hline 73. & J. O. & $1177-E$ & $\mathrm{~F}$ & 2 & $2 \mathrm{~A}$ & 1 & 0 & 15,08 \\
\hline 74. & L. F. D. & $1286-E$ & $\mathrm{M}$ & 2 & $2 \mathrm{~A}$ & 1 & 0 & 13,33 \\
\hline 75. & L. G. C. S. & $1288-E$ & $\mathrm{M}$ & 2 & $2 \mathrm{~A}$ & 2 & 0 & 15,33 \\
\hline 76. & L. J.P.P. & $1301-E$ & $M$ & 2 & $2 \mathrm{~A}$ & 1 & 0 & 13,50 \\
\hline 77. & L. C. M. & $1307-E$ & $\mathrm{~F}$ & 2 & $2 \mathrm{~A}$ & 1 & 0 & 14,00 \\
\hline 78. & L. M. M. & $1322-E$ & $\mathrm{~F}$ & 2 & $2 \mathrm{~A}$ & 2 & 0 & 17,50 \\
\hline 79. & L. F. R. & $1354-E$ & $\mathrm{~F}$ & 2 & $2 \mathrm{~B}$ & 1 & 0 & 11,92 \\
\hline 80. & L. A. B. P. & $680-A c$ & $\mathrm{~F}$ & 2 & $2 \mathrm{~A}$ & 1 & 4 & 14,00 \\
\hline 81. & L.F.T. & $1375-E$ & $\mathrm{~F}$ & 2 & $2 \mathrm{~B}$ & 1 & 0 & 13,08 \\
\hline 82. & L. A. S. & $1377-E$ & $\mathrm{M}$ & 2 & $2 \mathrm{~B}$ & 2 & 0 & 17,25 \\
\hline 83. & L. A M. R. & $39-A C$ & $\mathrm{M}$ & 2 & $2 \mathrm{~A}$ & 2 & 0 & 15,83 \\
\hline 84. & L. C. O. J. & 334 - PG & $\mathrm{M}$ & 2 & $2 \mathrm{~A}$ & 1 & 0 & 13,92 \\
\hline 85. & L. E. B. & $1394-E$ & $\mathrm{M}$ & 2 & $2 \mathrm{~B}$ & 1 & 0 & 12,33 \\
\hline 86. & L. G. C. R. & $790-A c$ & $\mathrm{M}$ & 2 & $2 \mathrm{~A}$ & 1 & 0 & 12,83 \\
\hline 87. & M. M. B. & $227-A c$ & $\mathrm{M}$ & 2 & $2 \mathrm{~A}$ & 1 & 0 & 11,16 \\
\hline 88. & M. E. B. & $1456-E$ & $\mathrm{M}$ & 2 & $2 \mathrm{~A}$ & 1 & 0 & 19,00 \\
\hline 89. & M. R. B. V. & $1523-E$ & $\mathrm{M}$ & 2 & $2 \mathrm{~B}$ & 1 & 0 & 11,50 \\
\hline 90. & M. V. R. S. & $1528-E$ & $M$ & 2 & $2 \mathrm{~B}$ & 1 & 2 & 12,75 \\
\hline 91. & M. E. A. P. & 126 - PG & $\mathrm{F}$ & 2 & $2 \mathrm{~B}$ & 1 & 3 & 21,50 \\
\hline 92. & M. A. O. S. & $48-A c$ & $\mathrm{~F}$ & 2 & $2 \mathrm{~A}$ & 2 & 0 & 17,17 \\
\hline 93. & M. C. M. B. & $1606-E$ & $\mathrm{~F}$ & 2 & $2 \mathrm{~A}$ & 1 & 0 & 15,00 \\
\hline
\end{tabular}


TABELA A - 3

\begin{tabular}{|c|c|c|c|c|c|c|c|}
\hline Paciente & $\begin{array}{c}\text { Número } \\
\text { de arquivo }\end{array}$ & Gênero & Grupo & Subgrupo & $\begin{array}{c}\text { Tipo de } \\
\text { Classe II }\end{array}$ & APINF & IDADEI \\
\hline 94. M. F. Z. C. & $1608-E$ & $\mathrm{~F}$ & 2 & $2 \mathrm{~A}$ & 1 & 0 & 12,00 \\
\hline 95. P.C. P. & $1731-E$ & $\mathrm{~F}$ & 2 & $2 \mathrm{~B}$ & 2 & 0 & 13,33 \\
\hline 96. P. G. O. & $1775-E$ & $\mathrm{~F}$ & 2 & $2 \mathrm{~A}$ & 1 & 4 & 12,92 \\
\hline 97. R. O. T.P. & $1807-E$ & $\mathrm{~F}$ & 2 & $2 \mathrm{~A}$ & 2 & 0 & 13,33 \\
\hline 98. R. R. M. & $224-A C$ & $\mathrm{M}$ & 2 & $2 B$ & 1 & 0 & 9,42 \\
\hline 99. R. C. C. & $1838-E$ & $\mathrm{~F}$ & 2 & $2 \mathrm{~A}$ & 1 & 0 & 14,00 \\
\hline 100. R. F. & $1837-E$ & $\mathrm{~F}$ & 2 & $2 \mathrm{~A}$ & 1 & 0 & 13,08 \\
\hline 101. R. H. C. & 573 - PG & $\mathrm{M}$ & 2 & $2 \mathrm{~B}$ & 1 & 4 & 10,67 \\
\hline 102. R. P. O. & $1884-E$ & $\mathrm{M}$ & 2 & $2 \mathrm{~B}$ & 2 & 1 & 12,00 \\
\hline 103. R. L. P. & $1953-E$ & $\mathrm{~F}$ & 2 & $2 \mathrm{~B}$ & 1 & 0 & 11,42 \\
\hline 104. R. N. S. & $1967-E$ & $\mathrm{~F}$ & 2 & $2 \mathrm{~A}$ & 1 & 0 & 11,67 \\
\hline 105. S. A. & $1984-E$ & $\mathrm{M}$ & 2 & $2 \mathrm{~A}$ & 1 & 0 & 12,33 \\
\hline 106. S. N. L. & $2005-E$ & $\mathrm{M}$ & 2 & $2 \mathrm{~A}$ & 2 & 0 & 19,25 \\
\hline 107. T.D.S. & $31-A c$ & $\mathrm{~F}$ & 2 & $2 \mathrm{~A}$ & 2 & 0 & 13,17 \\
\hline 108. T. T.F. & $2078-E$ & $\mathrm{~F}$ & 2 & $2 \mathrm{~A}$ & 1 & 0 & 11,08 \\
\hline 109. V.R. M. & $2158-E$ & $\mathrm{~F}$ & 2 & $2 \mathrm{~A}$ & 1 & 2 & 14,25 \\
\hline 110. W. S. T. & $2215-E$ & $\mathrm{M}$ & 2 & $2 \mathrm{~A}$ & 1 & 0 & 11,83 \\
\hline 111. W. A. V. B. & $2225-E$ & $\mathrm{M}$ & 2 & $2 \mathrm{~A}$ & 1 & 2 & 13,00 \\
\hline 112. W. B. & 141-PG & M & 2 & $2 \mathrm{~A}$ & 1 & 0 & 13,00 \\
\hline
\end{tabular}


TABELA A - 4

\begin{tabular}{|c|c|c|c|c|c|c|c|c|c|c|c|c|}
\hline & Paciente & IPTI & PARI & IPTF & PARF & DIFIPT & DIFPAR & PCIPT & PCPAR & IETIPT & IETPAR & TTRAT \\
\hline 1. & A. C. G. & 6,07 & 17 & 4,02 & 14 & 2,05 & 3 & 33,77 & 17,65 & 1,06 & 0,56 & 31,76 \\
\hline 2. & A. S. S. & 7,17 & 21 & 0,00 & 0 & 7,17 & 21 & 100,00 & 100,00 & 4,45 & 4,45 & 22,45 \\
\hline 3. & A. C. I. & 6,27 & 17 & 1,57 & 4 & 4,70 & 13 & 74,96 & 76,47 & 2,81 & 2,87 & 26,63 \\
\hline 4. & A. L. O. G. & 7,87 & 23 & 0,27 & 4 & 7,60 & 19 & 96,57 & 82,61 & 4,51 & 3,86 & 21,40 \\
\hline 5. & B. S. & 7,37 & 19 & 0,00 & 0 & 7,37 & 19 & 100,00 & 100,00 & 2,32 & 2,32 & 43,07 \\
\hline 6. & C. L. B. & 9,47 & 30 & 1,80 & 8 & 7,67 & 22 & 80,99 & 73,33 & 1,73 & 1,57 & 46,75 \\
\hline 7. & C. A. P. & 8,52 & 33 & 1,97 & 5 & 6,55 & 28 & 76,88 & 84,85 & 2,46 & 2,71 & 31,30 \\
\hline 8. & C. C. U. & 6,07 & 11 & 0,27 & 4 & 5,80 & 7 & 95,55 & 63,64 & 5,55 & 3,69 & 17,23 \\
\hline 9. & C. L. C. & 7,77 & 31 & 0,27 & 0 & 7,50 & 31 & 96,53 & 100,00 & 3,75 & 3,89 & 25,71 \\
\hline 10. & C. G. S. C. A. & 8,07 & 21 & 2,60 & 7 & 5,47 & 14 & 67,78 & 66,67 & 1,55 & 1,53 & 43,63 \\
\hline 11. & C. A. S. .S & 7,27 & 22 & 0,00 & 0 & 7,27 & 22 & 100,00 & 100,00 & 4,20 & 4,20 & 23,84 \\
\hline 12. & D. M. O. & 7,37 & 22 & 0,27 & 0 & 7,10 & 22 & 96,34 & 100,00 & 4,31 & 4,47 & 22,36 \\
\hline 13. & D. C. J. & 9,37 & 23 & 2,60 & 9 & 6,77 & 14 & 72,25 & 60,87 & 3,61 & 3,04 & 20,02 \\
\hline 14. & D. D. J. & 7,17 & 23 & 4,02 & 11 & 3,15 & 12 & 43,93 & 52,17 & 1,39 & 1,66 & 31,50 \\
\hline 15. & D. M. & 10,77 & 40 & 1,77 & 3 & 9,00 & 37 & 83,57 & 92,50 & 2,86 & 3,16 & 29,23 \\
\hline 16. & E. W. L. & 9,27 & 39 & 6,40 & 20 & 2,87 & 19 & 30,96 & 48,72 & 1,32 & 2,08 & 23,38 \\
\hline 17. & E. A. S. & 7,47 & 15 & 2,60 & 9 & 4,87 & 6 & 65,19 & 40,00 & 3,06 & 1,88 & 21,30 \\
\hline 18. & E. M & 7,97 & 29 & 1,50 & 11 & 6,47 & 18 & 81,18 & 62,07 & 2,54 & 1,94 & 32,02 \\
\hline 19. & E. N. S. & 7,87 & 27 & 2,60 & 7 & 5,27 & 20 & 66,96 & 74,07 & 1,36 & 1,50 & 49,41 \\
\hline 20. & F. A. R. & 9,67 & 26 & 4,55 & 16 & 5,12 & 10 & 52,95 & 38,46 & 2,12 & 1,54 & 25,02 \\
\hline 21. & F. C. & 7,27 & 25 & 0,27 & 2 & 7,00 & 23 & 96,29 & 92,00 & 3,51 & 3,35 & 27,45 \\
\hline 22. & F. M. A. & 8,07 & 22 & 0,00 & 0 & 8,07 & 22 & 100,00 & 100,00 & 4,48 & 4,48 & 22,32 \\
\hline 23. & G. A. G. & 6,87 & 19 & 1,50 & 6 & 5,37 & 13 & 78,17 & 68,42 & 3,44 & 3,01 & 22,75 \\
\hline 24. & H. C. & 6,37 & 16 & 0,00 & 0 & 6,37 & 16 & 100,00 & 100,00 & 2,62 & 2,62 & 38,24 \\
\hline 25. & J.A. A. C. & 8,17 & 18 & 1,80 & 6 & 6,37 & 12 & 77,97 & 66,67 & 2,93 & 2,50 & 26,63 \\
\hline 26. & J. C.P. & 13,17 & 46 & 2,60 & 9 & 10,57 & 37 & 80,26 & 80,43 & 2,42 & 2,43 & 33,14 \\
\hline 27. & J. D. & 7,77 & 28 & 0,27 & 0 & 7,50 & 28 & 96,53 & 100,00 & 6,35 & 6,58 & 15,19 \\
\hline 28. & J. S. G. & 6,47 & 17 & 1,50 & 9 & 4,97 & 8 & 76,82 & 47,06 & 3,39 & 2,08 & 22,65 \\
\hline 29. & L. F. M. & 7,17 & 18 & 4,02 & 16 & 3,15 & 2 & 43,93 & 11,11 & 1,72 & 0,43 & 25,55 \\
\hline 30. & L. B. P. & 8,17 & 28 & 1,77 & 3 & 6,40 & 25 & 78,34 & 89,29 & 3,58 & 4,08 & 21,90 \\
\hline 31. & L. G. B. & 8,17 & 24 & 0,00 & 0 & 8,17 & 24 & 100,00 & 100,00 & 3,59 & 3,59 & 27,88 \\
\hline 32. & M. G. S. & 6,97 & 12 & 6,67 & 18 & 0,30 & -6 & 4,30 & $-50,00$ & 0,10 & $-1,19$ & 41,98 \\
\hline 33. & M. M. L. & 7,77 & 27 & 0,00 & 0 & 7,77 & 27 & 100,00 & 100,00 & 2,33 & 2,33 & 42,87 \\
\hline 34. & M. A. C. & 7,67 & 23 & 0,00 & 0 & 7,67 & 23 & 100,00 & 100,00 & 5,56 & 5,56 & 17,98 \\
\hline 35. & M. T. & 6,67 & 19 & 3,40 & 15 & 3,27 & 4 & 49,03 & 21,05 & 1,27 & 0,55 & 38,56 \\
\hline 36. & M. L. C. & 5,97 & 21 & 0,27 & 2 & 5,70 & 19 & 95,48 & 90,48 & 4,21 & 3,99 & 22,65 \\
\hline 37. & N. C. & 7,07 & 20 & 0,57 & 6 & 6,50 & 14 & 91,94 & 70,00 & 3,95 & 3,01 & 23,28 \\
\hline 38. & N. H. G. & 6,57 & 16 & 1,80 & 8 & 4,77 & 8 & 72,60 & 50,00 & 1,59 & 1,09 & 45,80 \\
\hline 39. & P. C. G. & 9,87 & 25 & 1,50 & 6 & 8,37 & 19 & 84,80 & 76,00 & 3,00 & 2,69 & 28,27 \\
\hline 40. & P. M. C. & 8,97 & 32 & 0,27 & 2 & 8,70 & 30 & 96,99 & 93,75 & 2,81 & 2,71 & 34,55 \\
\hline 41. & R. H. C. & 9,97 & 37 & 0,27 & 0 & 9,70 & 37 & 97,29 & 100,00 & 3,28 & 3,37 & 29,69 \\
\hline 42. & V. L. U. V. & 9,17 & 28 & 0,57 & 4 & 8,60 & 24 & 93,78 & 85,71 & 2,17 & 1,99 & 43,17 \\
\hline 43. & W. M. L. & 8,97 & 36 & 0,00 & 0 & 8,97 & 36 & 100,00 & 100,00 & 1,80 & 1,80 & 55,69 \\
\hline 44. & A. L. & 7,77 & 26 & 1,50 & 2 & 6,27 & 24 & 80,69 & 92,31 & 3,72 & 4,25 & 21,70 \\
\hline 45. & A. B. J. & 7,47 & 23 & 0,00 & 0 & 7,47 & 23 & 100,00 & 100,00 & 2,01 & 2,01 & 49,68 \\
\hline 46. & A. M. & 7,37 & 13 & 1,50 & 7 & 5,87 & 6 & 79,65 & 46,15 & 3,04 & 1,76 & 26,20 \\
\hline 47. & A. M. G. & 5,67 & 18 & 0,27 & 0 & 5,40 & 18 & 95,24 & 100,00 & 6,88 & 7,22 & 13,84 \\
\hline 48. & A. M. & 8,67 & 26 & 1,50 & 12 & 7,17 & 14 & 82,70 & 53,85 & 3,81 & 2,48 & 21,73 \\
\hline
\end{tabular}


TABELA A - 5

\begin{tabular}{|c|c|c|c|c|c|c|c|c|c|c|c|c|}
\hline & Paciente & IPTI & PARI & IPTF & PARF & DIFIPT & DIFPAR & PCIPT & PCPAR & IETIPT & IETPAR & TTRAT \\
\hline 49 & A. O. R. & 10,27 & 34 & 0,00 & 0 & 10,27 & 34 & 100,00 & 100,00 & 5,17 & 5,17 & 19,33 \\
\hline 50 & A. L. R. D. & 8,27 & 17 & 0,37 & 0 & 7,90 & 17 & 95,53 & 100,00 & 1,94 & 2,03 & 49,25 \\
\hline 51 & A. P. L. & 8,37 & 35 & 2,60 & 4 & 5,77 & 31 & 68,94 & 88,57 & 2,08 & 2,68 & 33,07 \\
\hline 52 & A. G. B. & 7,27 & 24 & 1,77 & 3 & 5,50 & 21 & 75,65 & 87,50 & 2,84 & 3,28 & 26,66 \\
\hline 53 & A. L. B. & 6,37 & 20 & 0,27 & 0 & 6,10 & 20 & 95,76 & 100,00 & 3,92 & 4,09 & 24,43 \\
\hline 54 & B. B. A. & 8,77 & 32 & 0,00 & 0 & 8,77 & 32 & 100,00 & 100,00 & 3,07 & 3,07 & 32,55 \\
\hline 55 & B. L. L. & 7,17 & 12 & 0,27 & 2 & 6,90 & 10 & 96,23 & 83,33 & 2,14 & 1,85 & 45,07 \\
\hline 56 & B. T. & 10,07 & 33 & 1,50 & 0 & 8,57 & 33 & 85,10 & 100,00 & 5,34 & 6,27 & 15,95 \\
\hline 57 & C. S. Z. & 7,67 & 24 & 0,00 & 0 & 7,67 & 24 & 100,00 & 100,00 & 5,23 & 5,23 & 19,13 \\
\hline 58 & C. R. M. F. & 7,57 & 22 & 0,27 & 0 & 7,30 & 22 & 96,43 & 100,00 & 4,19 & 4,35 & 23,01 \\
\hline 59 & D. B. P. & 8,07 & 23 & 1,50 & 3 & 6,57 & 20 & 81,41 & 86,96 & 1,48 & 1,58 & 55,10 \\
\hline 60 & D. H. D. & 6,37 & 15 & 0,00 & 2 & 6,37 & 13 & 100,00 & 86,67 & 7,66 & 6,64 & 13,05 \\
\hline 61 & E. J. D. & 7,37 & 21 & 1,27 & 2 & 6,10 & 19 & 82,77 & 90,48 & 4,93 & 5,39 & 16,80 \\
\hline 62 & E. K. & 7,37 & 10 & 0,27 & 5 & 7,10 & 5 & 96,34 & 50,00 & 5,17 & 2,68 & 18,64 \\
\hline 63 & E. S.P. & 7,07 & 17 & 0,27 & 0 & 6,80 & 17 & 96,18 & 100,00 & 4,36 & 4,53 & 22,06 \\
\hline 64 & E. A. M. & 8,07 & 27 & 0,27 & 0 & 7,80 & 27 & 96,65 & 100,00 & 3,89 & 4,02 & 24,85 \\
\hline 65 & E. C. D. & 5,57 & 12 & 0,00 & 0 & 5,57 & 12 & 100,00 & 100,00 & 5,36 & 5,36 & 18,64 \\
\hline 66 & G. A. S. & 7,67 & 29 & 1,50 & 7 & 6,17 & 22 & 80,44 & 75,86 & 4,02 & 3,79 & 20,02 \\
\hline 67 & H. A. J. S. & 7,57 & 25 & 1,50 & 4 & 6,07 & 21 & 80,18 & 84,00 & 3,71 & 3,88 & 21,63 \\
\hline 68 & H.S. S. & 7,77 & 22 & 0,27 & 2 & 7,50 & 20 & 96,53 & 90,91 & 6,19 & 5,83 & 15,58 \\
\hline 69 & I. E. B. P. C. & 8,87 & 25 & 1,80 & 7 & 7,07 & 18 & 79,71 & 72,00 & 2,84 & 2,56 & 28,08 \\
\hline 70 & I. A. F. M. & 8,47 & 28 & 1,50 & 4 & 6,97 & 24 & 82,29 & 85,71 & 7,47 & 7,78 & 11,01 \\
\hline 71 & J.A. T. & 7,37 & 20 & 0,27 & 0 & 7,10 & 20 & 96,34 & 100,00 & 4,60 & 4,77 & 20,94 \\
\hline 72 & J.T. J. & 8,57 & 13 & 0,00 & 0 & 8,57 & 13 & 100,00 & 100,00 & 1,97 & 1,97 & 50,83 \\
\hline 73 & J. O. & 6,97 & 15 & 0,27 & 6 & 6,70 & 9 & 96,13 & 60,00 & 2,56 & 1,60 & 37,51 \\
\hline 74 & L. F. D. & 7,57 & 19 & 0,00 & 0 & 7,57 & 19 & 100,00 & 100,00 & 4,22 & 4,22 & 23,70 \\
\hline 75 & L. G. C. S. & 6,97 & 15 & 0,27 & 0 & 6,70 & 15 & 96,13 & 100,00 & 3,70 & 3,85 & 25,97 \\
\hline 76 & L. J.P.P. & 9,27 & 41 & 0,37 & 0 & 8,90 & 41 & 96,01 & 100,00 & 3,86 & 4,02 & 24,85 \\
\hline 77 & L. C. M. & 8,27 & 23 & 1,50 & 5 & 6,77 & 18 & 81,86 & 78,26 & 3,49 & 3,34 & 23,44 \\
\hline 78 & L. M. M. & 5,77 & 11 & 0,27 & 2 & 5,50 & 9 & 95,32 & 81,82 & 3,64 & 3,12 & 26,20 \\
\hline 79 & L. F. R. & 7,87 & 18 & 0,27 & 2 & 7,60 & 16 & 96,57 & 88,89 & 3,31 & 3,04 & 29,19 \\
\hline 80 & L. A. B. P. & 7,17 & 22 & 1,77 & 10 & 5,40 & 12 & 75,31 & 54,55 & 4,15 & 3,01 & 18,15 \\
\hline 81 & L. F. T. & 7,67 & 22 & 1,50 & 4 & 6,17 & 18 & 80,44 & 81,82 & 1,32 & 1,35 & 60,72 \\
\hline 82 & L. A. S. & 7,17 & 23 & 0,27 & 0 & 6,90 & 23 & 96,23 & 100,00 & 2,35 & 2,44 & 40,93 \\
\hline 83 & L. A M. R. & 5,97 & 28 & 0,00 & 0 & 5,97 & 28 & 100,00 & 100,00 & 3,37 & 3,37 & 29,69 \\
\hline 84 & L. C. O. J. & 7,67 & 24 & 1,77 & 10 & 5,90 & 14 & 76,92 & 58,33 & 3,11 & 2,36 & 24,72 \\
\hline 85 & L. E. B. & 6,87 & 20 & 1,50 & 0 & 5,37 & 20 & 78,17 & 100,00 & 3,86 & 4,94 & 20,25 \\
\hline 86 & L. G. C. R. & 10,77 & 33 & 0,37 & 2 & 10,40 & 31 & 96,56 & 93,94 & 4,48 & 4,36 & 21,53 \\
\hline 87 & M. M. B. & 6,07 & 16 & 1,50 & 4 & 4,57 & 12 & 75,29 & 75,00 & 3,04 & 3,03 & 24,76 \\
\hline 88 & M. E. B. & 8,47 & 21 & 1,50 & 6 & 6,97 & 15 & 82,29 & 71,43 & 3,44 & 2,98 & 23,93 \\
\hline 89 & M. R. B. V. & 8,07 & 26 & 1,50 & 4 & 6,57 & 22 & 81,41 & 84,62 & 3,51 & 3,65 & 23,21 \\
\hline 90 & M. V.R. S. & 7,47 & 23 & 0,00 & 0 & 7,47 & 23 & 100,00 & 100,00 & 3,59 & 3,59 & 27,85 \\
\hline 91 & M. E. A. P. & 8,27 & 24 & 1,77 & 5 & 6,50 & 19 & 78,60 & 79,17 & 3,59 & 3,62 & 21,86 \\
\hline 92 & M. A. O. S. & 5,97 & 13 & 0,00 & 0 & 5,97 & 13 & 100,00 & 100,00 & 2,66 & 2,66 & 37,64 \\
\hline 93 & M. C. M. B. & 8,77 & 28 & 0,00 & 0 & 8,77 & 28 & 100,00 & 100,00 & 3,11 & 3,11 & 32,12 \\
\hline 94 & M. F. Z. C. & 8,07 & 31 & 1,50 & 4 & 6,57 & 27 & 81,41 & 87,10 & 3,96 & 4,24 & 20,55 \\
\hline 95 & P. C. P. & 6,87 & 19 & 0,00 & 0 & 6,87 & 19 & 100,00 & 100,00 & 3,04 & 3,04 & 32,94 \\
\hline 96 & P. G. O. & 8,47 & 31 & 1,77 & 5 & 6,70 & 26 & 79,10 & 83,87 & 4,08 & 4,33 & 19,36 \\
\hline
\end{tabular}


TABELA A - 6

\begin{tabular}{|c|c|c|c|c|c|c|c|c|c|c|c|}
\hline Paciente & IPTI & PARI & IPTF & PARF & DIFIPT & DIFPAR & PCIPT & PCPAR & IETIPT & IETPAR & TTRAT \\
\hline R. O. T. P. & 6,87 & 26 & 0,27 & 4 & 6,60 & 22 & 96,07 & 84,62 & 4,59 & 4,04 & 20,94 \\
\hline R. R. M. & 5,87 & 17 & 0,00 & 0 & 5,87 & 17 & 100,00 & 100,00 & 4,18 & 4,18 & 23,93 \\
\hline R. C. C. & 7,37 & 18 & 1,50 & 4 & 5,87 & 14 & 79,65 & 77,78 & 3,44 & 3,36 & 23,15 \\
\hline 100. R. F. & 7,77 & 22 & 1,50 & 4 & 6,27 & 18 & 80,69 & 81,82 & 3,67 & 3,72 & 21,99 \\
\hline 101. R. H. C. & 9,97 & 42 & 0,00 & 0 & 9,97 & 42 & 100,00 & 100,00 & 2,50 & 2,50 & 40,04 \\
\hline 102. R. P. O. & 7,27 & 25 & 0,27 & 2 & 7,00 & 23 & 96,29 & 92,00 & 2,78 & 2,66 & 34,59 \\
\hline 103. R. L. P. & 9,17 & 31 & 0,00 & 0 & 9,17 & 31 & 100,00 & 100,00 & 3,21 & 3,21 & 31,20 \\
\hline 104. R. N. S. & 8,87 & 33 & 0,27 & 2 & 8,60 & 31 & 96,96 & 93,94 & 2,36 & 2,29 & 41,10 \\
\hline 105. S. A. & 6,07 & 20 & 0,00 & 0 & 6,07 & 20 & 100,00 & 100,00 & 4,43 & 4,43 & 22,55 \\
\hline 106. S. N. L. & 8,37 & 29 & 0,00 & 2 & 8,37 & 27 & 100,00 & 93,10 & 5,88 & 5,48 & 17,00 \\
\hline 107. T. D. S. & 8,67 & 27 & 0,57 & 2 & 8,10 & 25 & 93,43 & 92,59 & 2,68 & 2,65 & 34,88 \\
\hline 108. T. T. F. & 9,47 & 35 & 0,00 & 0 & 9,47 & 35 & 100,00 & 100,00 & 4,64 & 4,64 & 21,53 \\
\hline 109. V. R. M. & 8,67 & 39 & 0,00 & 0 & 8,67 & 39 & 100,00 & 100,00 & 4,54 & 4,54 & 22,03 \\
\hline 110. W. S. T. & 10,37 & 35 & 0,27 & 8 & 10,10 & 27 & 97,40 & 77,14 & 4,92 & 3,90 & 19,79 \\
\hline 111. W. A. V. B. & 7,77 & 29 & 0,27 & 4 & 7,50 & 25 & 96,53 & 86,21 & 3,62 & 3,23 & 26,66 \\
\hline W. B. & 10,07 & 33 & 0,00 & 0 & 10,07 & 33 & 100,00 & 100,00 & 3,23 & 3,23 & 31,00 \\
\hline
\end{tabular}


As tabelas A-7 a A-9 referem-se aos valores individuais de cada componente do índice PAR para cada paciente, dos grupos 1 e 2.

TABELA A - 7

\begin{tabular}{|c|c|c|c|c|c|c|c|}
\hline Paciente & $\mathrm{MC}$ & AP & OVJ & OVB & APINH & LM & PARF \\
\hline A. C. G. & 0 & 3 & 1 & 1 & 0 & 0 & 5 \\
\hline A.S. S. & 0 & 0 & 0 & 0 & 0 & 0 & 0 \\
\hline A. C. I. & 0 & 2 & 0 & 0 & 0 & 0 & 2 \\
\hline A. L. O. G. & 0 & 2 & 0 & 0 & 0 & 0 & 2 \\
\hline B. S. & 0 & 0 & 0 & 0 & 0 & 0 & 0 \\
\hline C. L. B. & 2 & 2 & 0 & 0 & 0 & 0 & 4 \\
\hline 7. C. A.P. & 1 & 1 & 0 & 1 & 0 & 0 & 3 \\
\hline C. C.U. & 0 & 2 & 0 & 0 & 0 & 0 & 2 \\
\hline 9. C. L. C. & 0 & 0 & 0 & 0 & 0 & 0 & 0 \\
\hline 10. C. G. S. C. A. & 0 & 2 & 0 & 1 & 0 & 0 & 3 \\
\hline 11. C. A. S. .S & 0 & 0 & 0 & 0 & 0 & 0 & 0 \\
\hline 12. D. M. O. & 0 & 0 & 0 & 0 & 0 & 0 & 0 \\
\hline 13. D. C. J. & 0 & 3 & 0 & 1 & 0 & 0 & 4 \\
\hline 14. D. D. J. & 0 & 0 & 0 & 1 & 0 & 0 & 1 \\
\hline 15. D. M. & 0 & 0 & 1 & 1 & 0 & 1 & 3 \\
\hline 16. E. W. L. & 0 & 2 & 2 & 2 & 0 & 0 & 6 \\
\hline 17. E. A. S. & 0 & 3 & 0 & 1 & 0 & 0 & 4 \\
\hline 18. E. $M$ & 0 & 3 & 1 & 0 & 0 & 0 & 4 \\
\hline 19. E. N.S. & 0 & 2 & 0 & 1 & 0 & 0 & 3 \\
\hline 20. F. A. R. & 0 & 3 & 2 & 0 & 0 & 0 & 5 \\
\hline 21. F. C. & 0 & 1 & 0 & 0 & 0 & 0 & 1 \\
\hline 22. F. M. A. & 0 & 0 & 0 & 0 & 0 & 0 & 0 \\
\hline 23. G. A. G. & 0 & 3 & 0 & 0 & 0 & 0 & 3 \\
\hline 24. H. C. & 0 & 0 & 0 & 0 & 0 & 0 & 0 \\
\hline 25. J. A. A. C. & 2 & 1 & 0 & 0 & 0 & 0 & 3 \\
\hline 26. J. C.P. & 0 & 3 & 0 & 1 & 0 & 0 & 4 \\
\hline 27. J. D. & 0 & 0 & 0 & 0 & 0 & 0 & 0 \\
\hline 28. J.S. G. & 0 & 2 & 1 & 0 & 0 & 0 & 3 \\
\hline 29. L. F. M. & 0 & 4 & 1 & 1 & 0 & 0 & 6 \\
\hline 30. L. B. P. & 0 & 0 & 0 & 1 & 0 & 0 & 1 \\
\hline 31. L. G. B. & 0 & 0 & 0 & 0 & 0 & 0 & 0 \\
\hline 32. M. G.S. & 0 & 4 & 2 & 0 & 0 & 0 & 6 \\
\hline 33. M. M. L. & 0 & 0 & 0 & 0 & 0 & 0 & 0 \\
\hline 34. M. A. C. & 0 & 0 & 0 & 0 & 0 & 0 & 0 \\
\hline 35. М. Т. & 0 & 2 & 1 & 1 & 0 & 1 & 5 \\
\hline 36. M. L. C. & 0 & 1 & 0 & 0 & 0 & 0 & 1 \\
\hline 37. N. C. & 2 & 1 & 0 & 0 & 0 & 0 & 3 \\
\hline 38. N. H. G. & 2 & 2 & 0 & 0 & 0 & 0 & 4 \\
\hline 39. P. C. G. & 0 & 3 & 0 & 0 & 0 & 0 & 3 \\
\hline 40. P. M. C. & 0 & 1 & 0 & 0 & 0 & 0 & 1 \\
\hline 41. R. H. C. & 0 & 0 & 0 & 0 & 0 & 0 & 0 \\
\hline 42. V. L. U. V. & 2 & 0 & 0 & 0 & 0 & 0 & 2 \\
\hline 43. W. M. L. & 0 & 0 & 0 & 0 & 0 & 0 & 0 \\
\hline 44. A. L. & 0 & 1 & 0 & 0 & 0 & 0 & 1 \\
\hline 45. A. B. J. & 0 & 0 & 0 & 0 & 0 & 0 & 0 \\
\hline
\end{tabular}


TABELA A - 8

\begin{tabular}{|c|c|c|c|c|c|c|c|}
\hline Paciente & MC & AP & OVJ & OVB & APINH & LM & PARF \\
\hline 46. A. M. & 0 & 2 & 0 & 1 & 0 & 0 & 3 \\
\hline 47. A. M. G. & 0 & 0 & 0 & 0 & 0 & 0 & 0 \\
\hline 48. A. M. & 0 & 2 & 1 & 0 & 0 & 1 & 4 \\
\hline 49. A. O. R. & 0 & 0 & 0 & 0 & 0 & 0 & 0 \\
\hline 50. A. L. R. D. & 0 & 0 & 0 & 0 & 0 & 0 & 0 \\
\hline 51. A. P. L. & 0 & 2 & 0 & 0 & 0 & 0 & 2 \\
\hline 52. A. G. B. & 0 & 0 & 0 & 1 & 0 & 0 & 1 \\
\hline 53. A. L. B. & 0 & 0 & 0 & 0 & 0 & 0 & 0 \\
\hline 54. B. B. A. & 0 & 0 & 0 & 0 & 0 & 0 & 0 \\
\hline 55. B. L. L. & 0 & 1 & 0 & 0 & 0 & 0 & 1 \\
\hline 56. B. T. & 0 & 0 & 0 & 0 & 0 & 0 & 0 \\
\hline 57. C. S.Z. & 0 & 0 & 0 & 0 & 0 & 0 & 0 \\
\hline 58. C. R. M. F. & 0 & 0 & 0 & 0 & 0 & 0 & 0 \\
\hline 59. D. B. P. & 0 & 0 & 0 & 1 & 0 & 0 & 1 \\
\hline 60. D. H. D. & 0 & 1 & 0 & 0 & 0 & 0 & 1 \\
\hline 61. E. J. D. & 1 & 0 & 0 & 0 & 0 & 0 & 1 \\
\hline 62. E. K. & 0 & 2 & 0 & 0 & 1 & 0 & 3 \\
\hline 63. E. S. P. & 0 & 0 & 0 & 0 & 0 & 0 & 0 \\
\hline 64. E. A. M. & 0 & 0 & 0 & 0 & 0 & 0 & 0 \\
\hline 65. E. C. D. & 0 & 0 & 0 & 0 & 0 & 0 & 0 \\
\hline 66. G. A.S. & 0 & 2 & 0 & 1 & 0 & 0 & 3 \\
\hline 67. H. A. J. S. & 0 & 2 & 0 & 0 & 0 & 0 & 2 \\
\hline 68. H.S.S. & 0 & 1 & 0 & 0 & 0 & 0 & 1 \\
\hline 69. I. E. B. P. C. & 0 & 2 & 0 & 1 & 0 & 0 & 3 \\
\hline 70. I. A. F. M. & 0 & 2 & 0 & 0 & 0 & 0 & 2 \\
\hline 71. J. A. T. & 0 & 0 & 0 & 0 & 0 & 0 & 0 \\
\hline 72. J. T. J. & 0 & 0 & 0 & 0 & 0 & 0 & 0 \\
\hline 73. J. O. & 3 & 0 & 0 & 0 & 0 & 0 & 3 \\
\hline 74. L. F. D. & 0 & 0 & 0 & 0 & 0 & 0 & 0 \\
\hline 75. L. G. C. S. & 0 & 0 & 0 & 0 & 0 & 0 & 0 \\
\hline 76. L. J.P.P. & 0 & 0 & 0 & 0 & 0 & 0 & 0 \\
\hline 77. L. C. M. & 0 & 2 & 0 & 0 & 1 & 0 & 3 \\
\hline 78. L. M. M. & 0 & 1 & 0 & 0 & 0 & 0 & 1 \\
\hline 79. L. F. R. & 0 & 1 & 0 & 0 & 0 & 0 & 1 \\
\hline 80. L. A. B. P. & 0 & 1 & 1 & 1 & 0 & 0 & 3 \\
\hline 81. L.F.T. & 0 & 2 & 0 & 0 & 0 & 0 & 2 \\
\hline 82. L. A. S. & 0 & 0 & 0 & 0 & 0 & 0 & 0 \\
\hline 83. L. A M. R. & 0 & 0 & 0 & 0 & 0 & 0 & 0 \\
\hline 84. L. C. O. J. & 0 & 1 & 1 & 1 & 0 & 0 & 3 \\
\hline 85. L. E. B. & 0 & 0 & 0 & 0 & 0 & 0 & 0 \\
\hline 86. L. G. C. R. & 0 & 1 & 0 & 0 & 0 & 0 & 1 \\
\hline 87. M. M. B. & 0 & 2 & 0 & 0 & 0 & 0 & 2 \\
\hline 88. M. E. B. & 0 & 3 & 0 & 0 & 0 & 0 & 3 \\
\hline 89. M. R. B. V. & 0 & 2 & 0 & 0 & 0 & 0 & 2 \\
\hline 90. M. V. R. S. & 0 & 0 & 0 & 0 & 0 & 0 & 0 \\
\hline 91. M. E. A.P. & 0 & 1 & 0 & 1 & 0 & 0 & 2 \\
\hline 92. M. A. O. S. & 0 & 0 & 0 & 0 & 0 & 0 & 0 \\
\hline 93. M. С. М. В. & 0 & 0 & 0 & 0 & 0 & 0 & 0 \\
\hline
\end{tabular}


TABELA A - 9

\begin{tabular}{|l|c|c|c|c|c|c|c|}
\hline \multicolumn{1}{|l|}{ Paciente } & MC & AP & OVJ & OVB & APINH & LM & PARF \\
\hline 94. M. F. Z. C. & 0 & 2 & 0 & 0 & 0 & 0 & 2 \\
\hline 95. P. C.P. & 0 & 0 & 0 & 0 & 0 & 0 & 0 \\
\hline 96. P. G. O. & 0 & 1 & 0 & 1 & 0 & 0 & 2 \\
\hline $97 . \quad$ R. O. T.P. & 0 & 2 & 0 & 0 & 0 & 0 & 2 \\
\hline $98 . \quad$ R. R. M. & 0 & 0 & 0 & 0 & 0 & 0 & 0 \\
\hline 99. R. C. C. & 0 & 2 & 0 & 0 & 0 & 0 & 2 \\
\hline 100. R. F. & 0 & 2 & 0 & 0 & 0 & 0 & 2 \\
\hline 101. R. H. C. & 0 & 0 & 0 & 0 & 0 & 0 & 0 \\
\hline 102. R.P. O. & 0 & 1 & 0 & 0 & 0 & 0 & 1 \\
\hline 103. R. L.P. & 0 & 0 & 0 & 0 & 0 & 0 & 0 \\
\hline 104. R. N. S. & 0 & 1 & 0 & 0 & 0 & 0 & 1 \\
\hline 105. S. A. & 0 & 0 & 0 & 0 & 0 & 0 & 0 \\
\hline 106. S. N. L. & 0 & 1 & 0 & 0 & 0 & 0 & 1 \\
\hline 107. T. D. S. & 0 & 1 & 0 & 0 & 0 & 0 & 1 \\
\hline 108. T. T. F. & 0 & 0 & 0 & 0 & 0 & 0 & 0 \\
\hline 109. V. R. M. & 0 & 0 & 0 & 0 & 0 & 0 & 0 \\
\hline 110. W. S. T. & 0 & 0 & 1 & 1 & 0 & 0 & 2 \\
\hline 111. W. A. V. B. & 0 & 2 & 0 & 0 & 0 & 0 & 2 \\
\hline 112. W. B. & 0 & 0 & 0 & 0 & 0 & 0 & 0 \\
\hline
\end{tabular}




\section{Universidade de São Paulo \\ Faculdade de Odontologia de Bauru}

Al. Dr. Octávio Pinheiro Brisolla, 9-75 - Bauru-SP - CEP 1701 2-001 - $C$ - : PABX (0XX14)3235-8000 - FAX (0XX14)3223-4670

\section{Comitê de Éftica em Pesquisa}

Processo n $08 / 2004$

Bauru, 02 de março de 2004.

Senhor Professor,

O projeto de pesquisa encaminhado a este Comitè de litica em Pesquisa em Seres Humanos, denominado "Resultados oclusais do tratamento d: classe II realizado sem extraçóes, comparados aos obtidos com extraç̃es de dois pré-molares superiores", de autoria de Sérgio Estelita Cavalcante Barros. fue sela desenvolvido sob sua orientação, foi enviado ao relator para avaliação.

$\mathrm{Na}$ reunião de 18 de fevereiro de 2004 o parecer do relator. aprovando o projeto, foi aceito pelo Comitê, considerando que não existem infraçic: éticas pendentes.

Informamos que após o envio do trabalho concluido. este (imiti enviará o parecer final, que será utilizado para publicação do trabalho.

Atenciosamente,

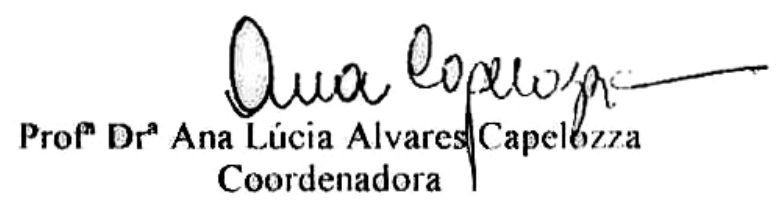

Ilm Sr. Prof. Dr. Guilherme dos Reis Pereira Janson

DD. Docente do Departamento de Odontopediatria, Ortodontia e Saude Coletiva 